\title{
تكاهل دور التدقيق الداخلي والخارجي لإنجاح أسلوب التقدير الذاتي في الهيئة العاهة للضرائب
}

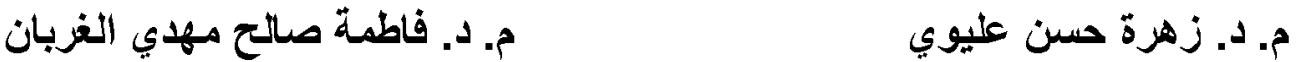 \\ كلية الإدارة والأقتصادـ الجامعة المستتصريةـ قسم المحاسبة فئة
}

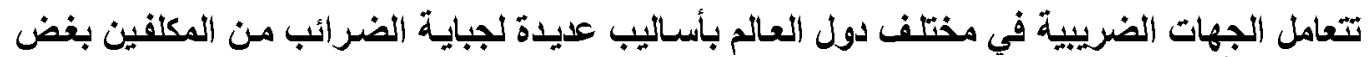

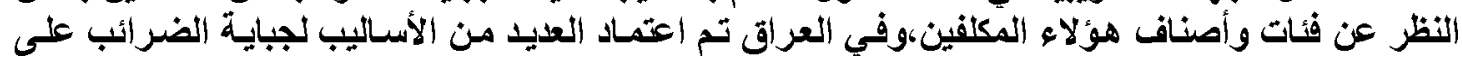

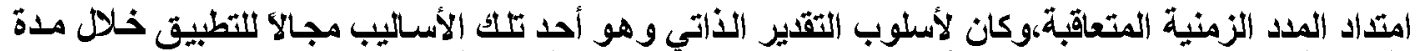

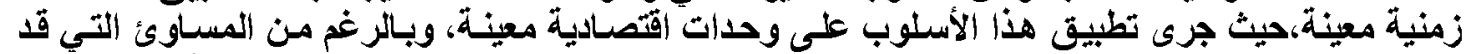

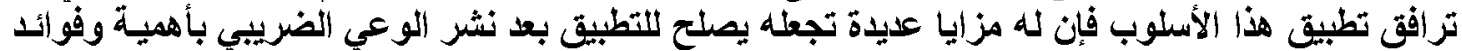

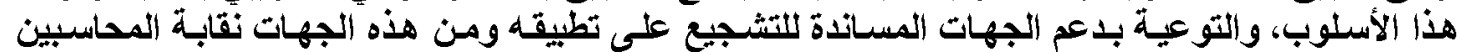
و والمدققين وديوان الرقابة المالية ومكاتب التدقيق و.....الخ.

وللتدقيق مجال مهم في إنجاح تطبيق أسلوب التقيلير الذاتى من قبل الهيئة العامة للضرائب، سواءو أكان

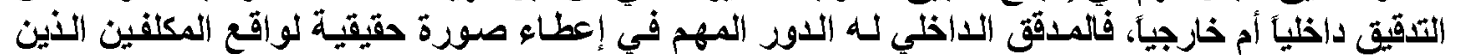

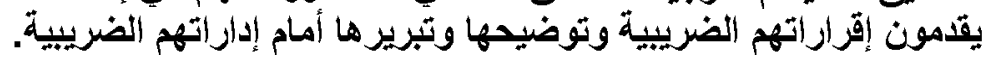

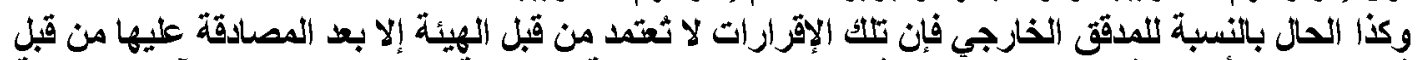

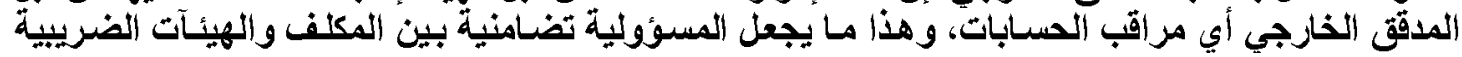

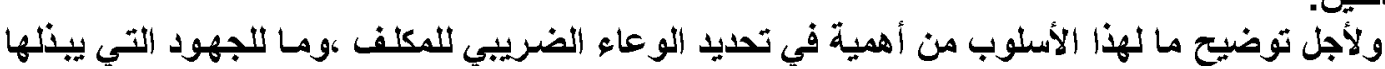

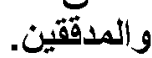

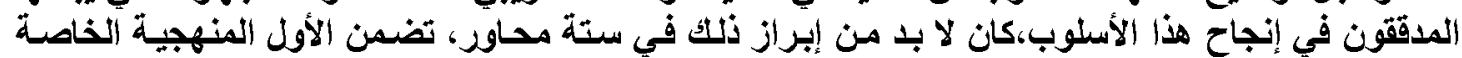

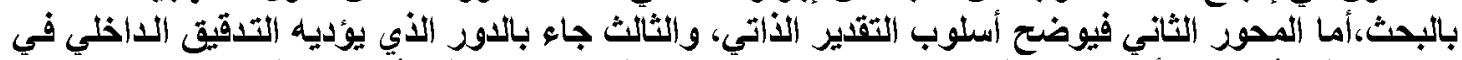

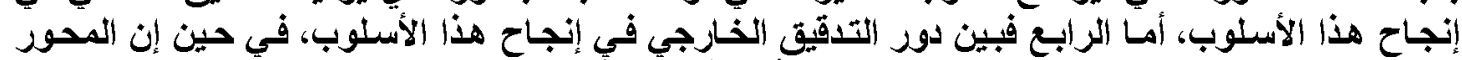

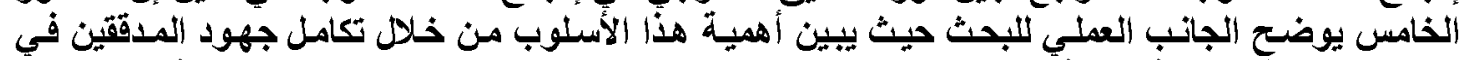

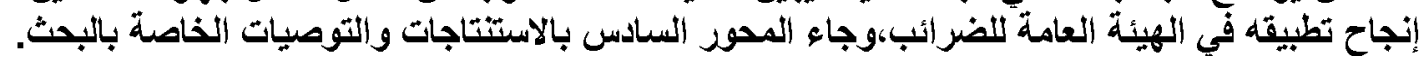




\section{المهور الأول- هنهجية البحث}

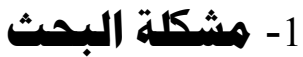

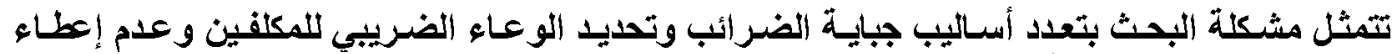

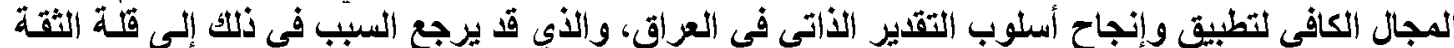

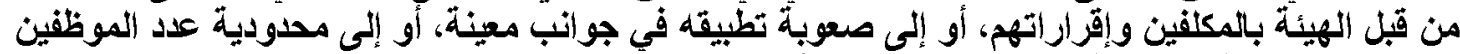
العاملين في اللهيئة بالمقارنة مع ما يحتاجه هذا الأسلوب التحقيق التهيق النجاح في التطبيق.

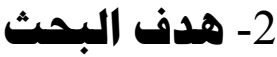

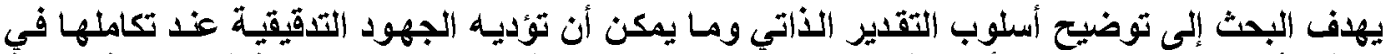

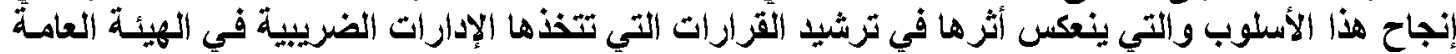

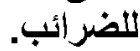

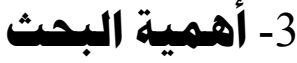

تتمثل الأهمية الخاصة بالبحث بالآتي:-

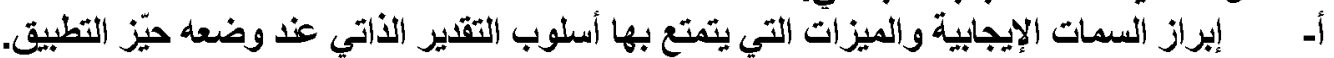

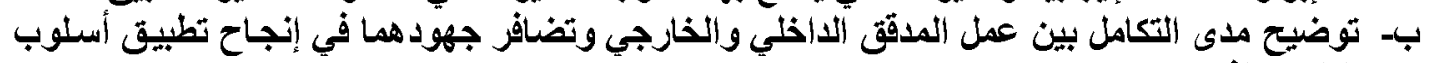

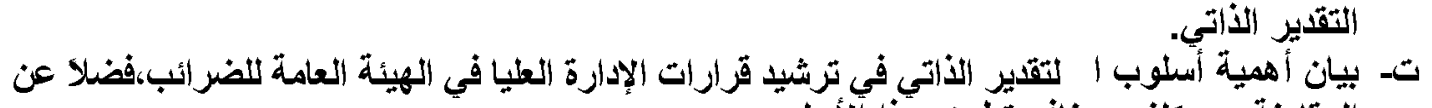

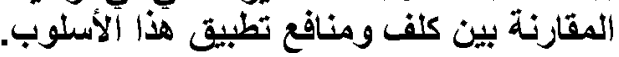

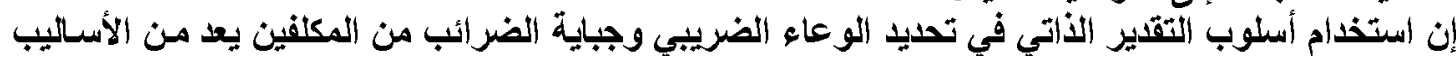

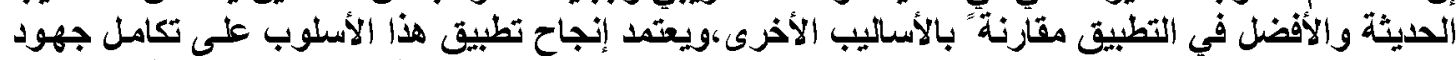

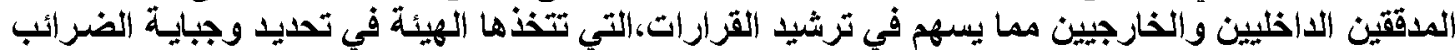


الذاتي ــألمينة العامةللضهائب

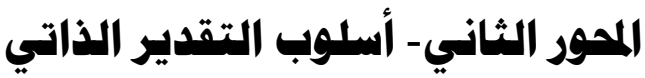

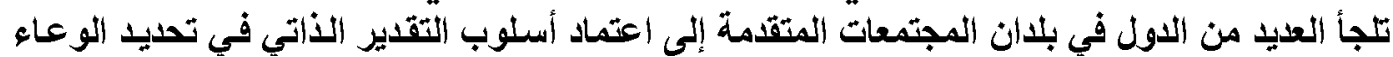

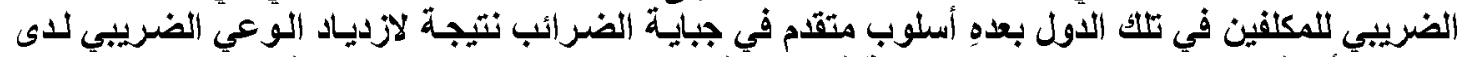

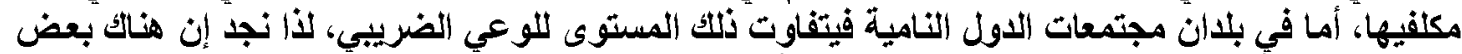

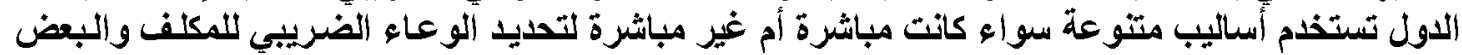

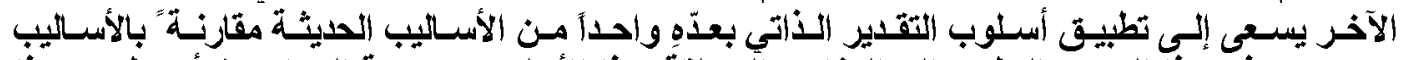

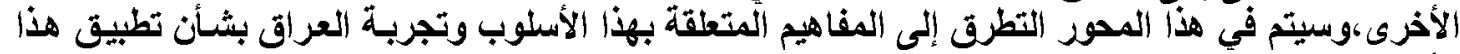

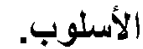
1- التقدير الآ|تي

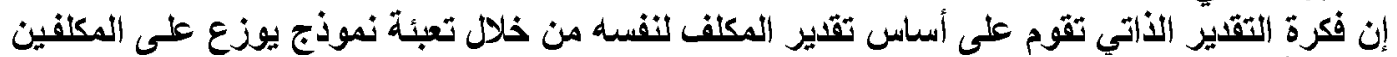

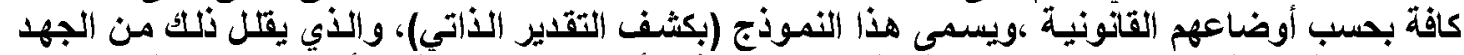

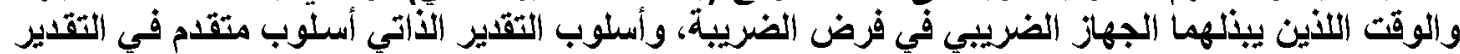

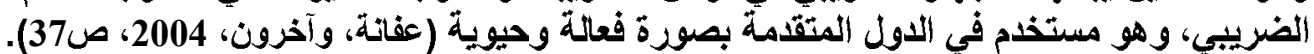

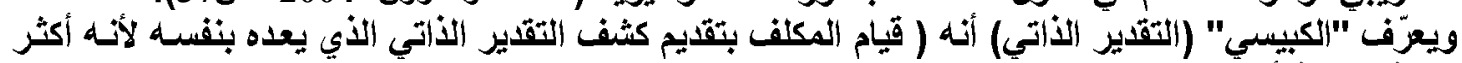

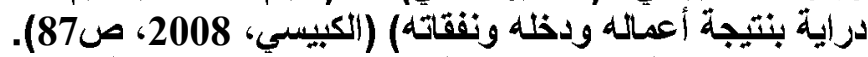

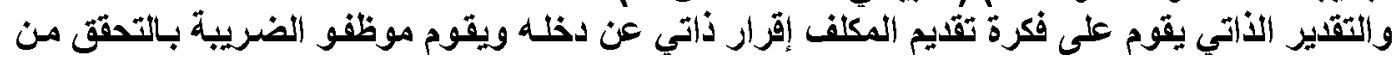

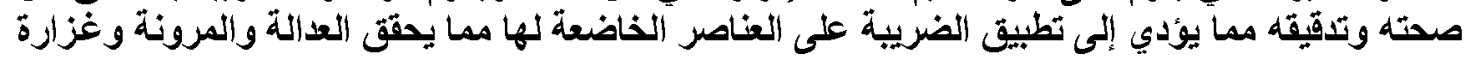

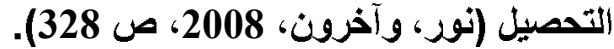

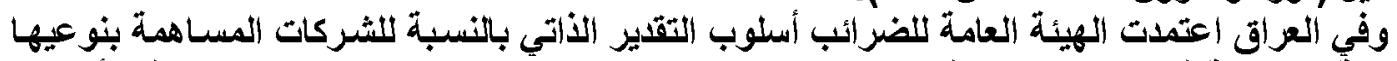

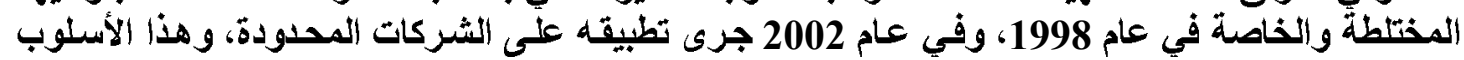

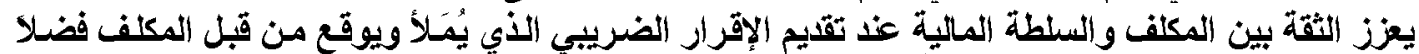

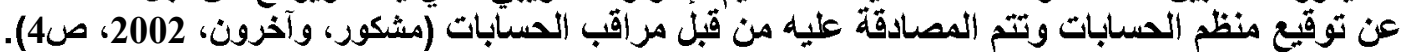

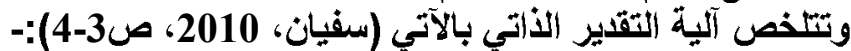

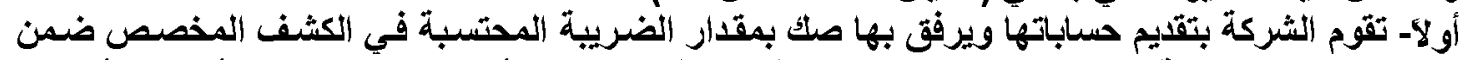

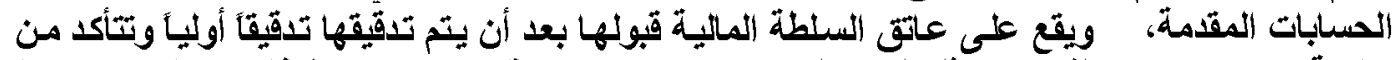

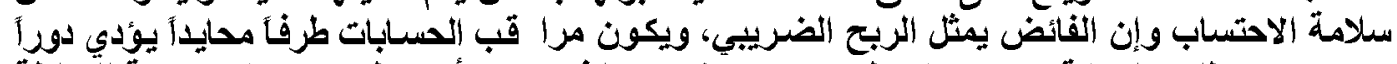

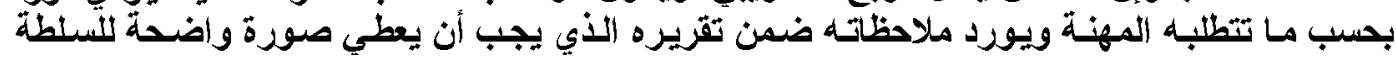

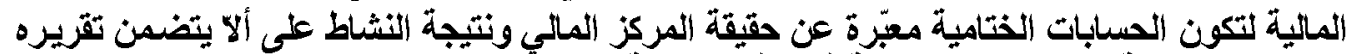

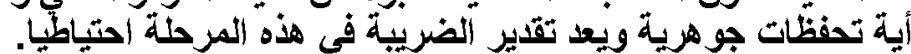

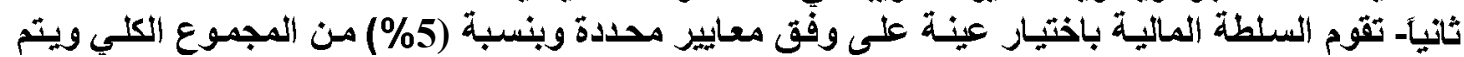

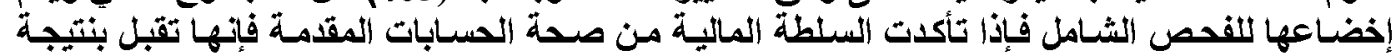

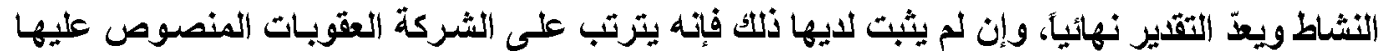

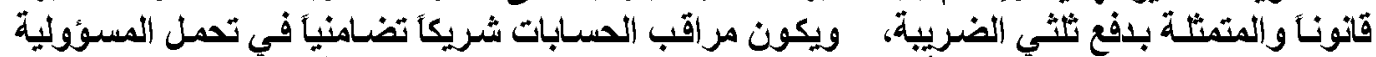

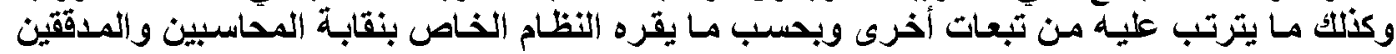
المعراقيين.

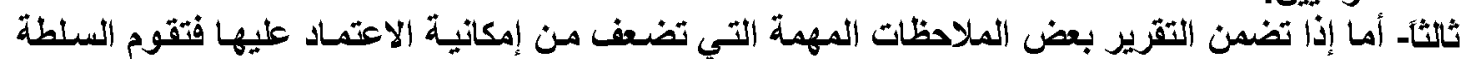

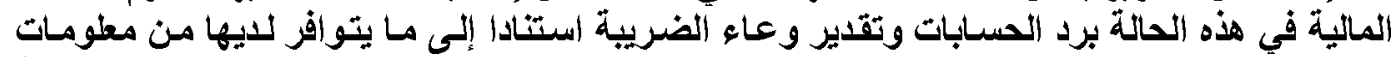

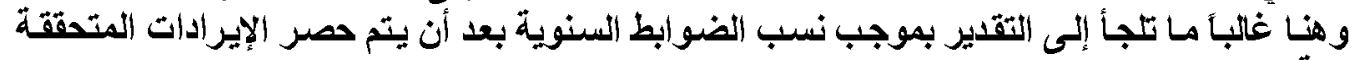

$$
\text { لشركة. }
$$

وتثار بهنا الصداد عدّة أسئلة أهمها:

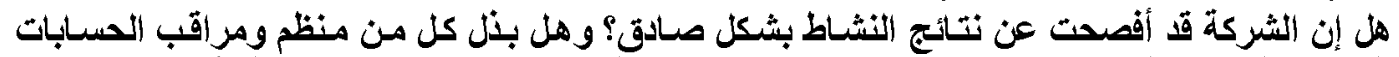

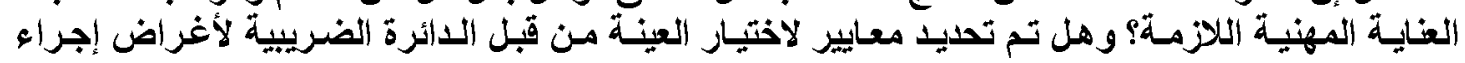




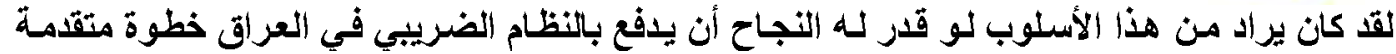

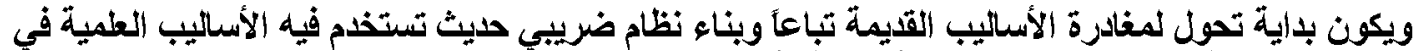

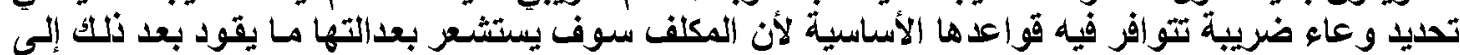

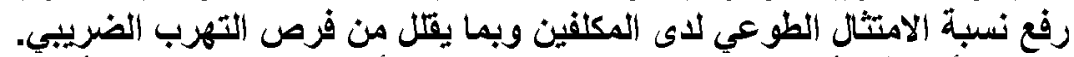

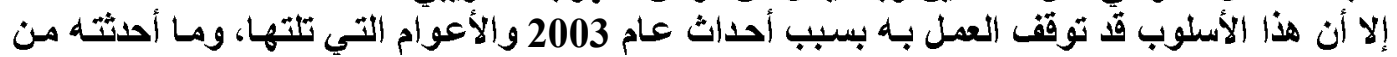

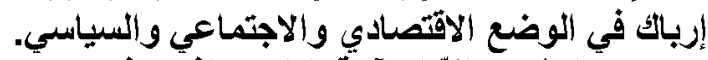

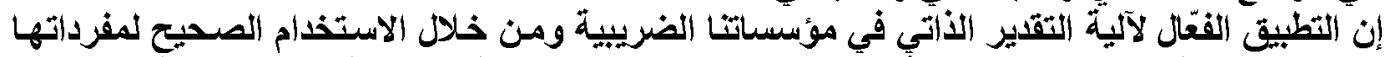

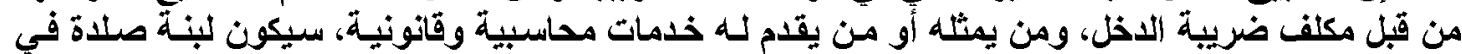

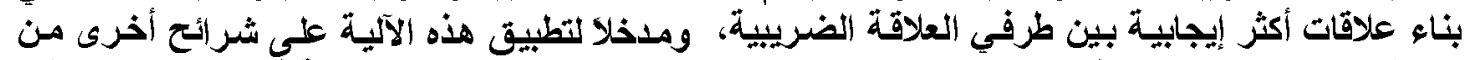

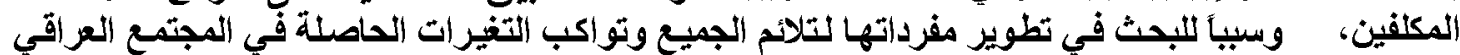

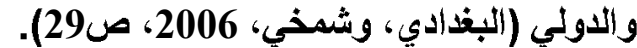
وجـاء هذا البحثث بعدّهِ خطوة أولى للحث على إعادة العمل بتطبيق هذا الأسلوب في تقدير دخل المكلفين الخاضع للضريبة. البح.

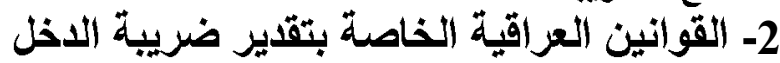

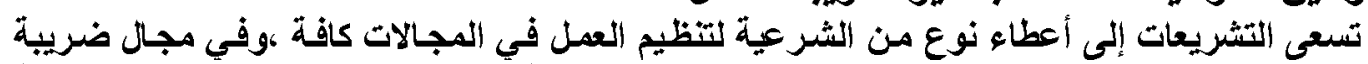

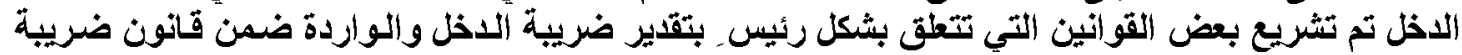

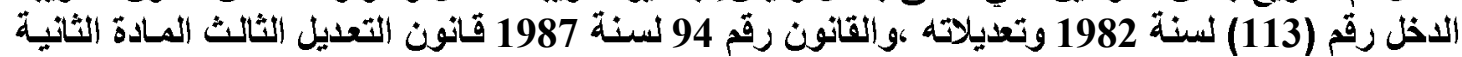

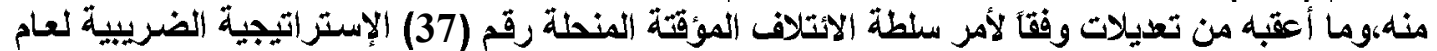

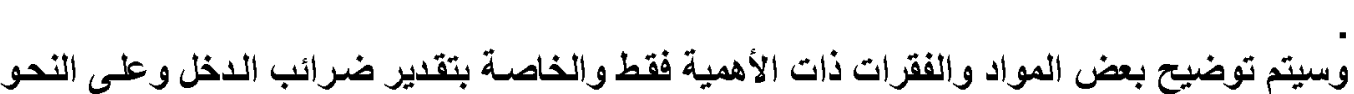
2003

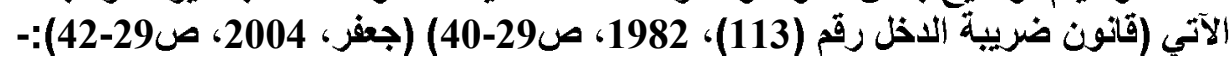

\section{قانانون ضريبة الاخل رقم 113 لسنة 1982 وتعديلاتهُ:}

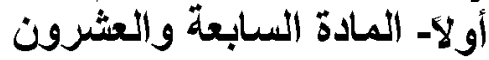

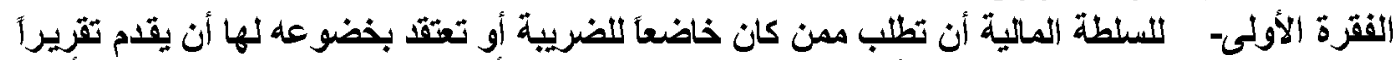

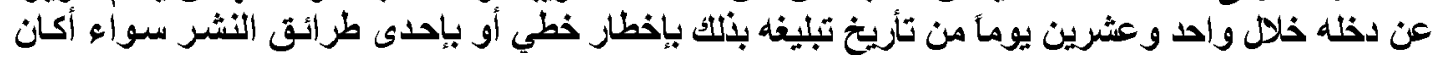

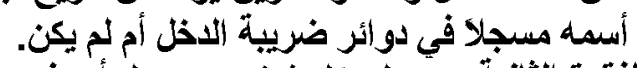

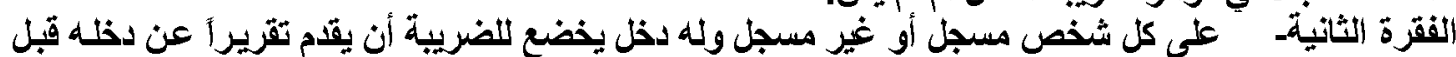

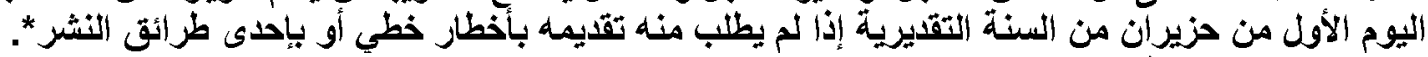

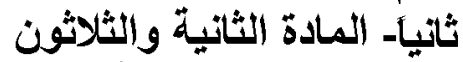

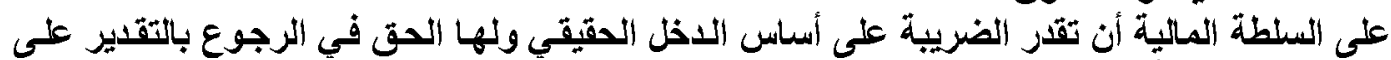

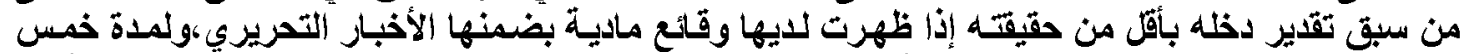

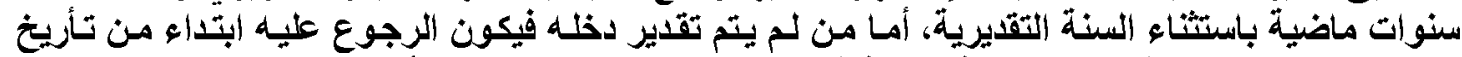

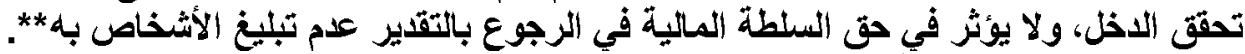

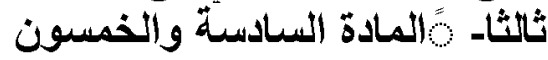

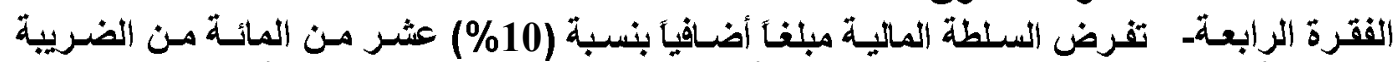

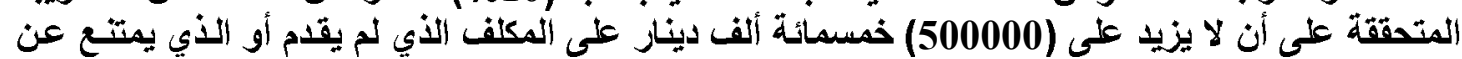

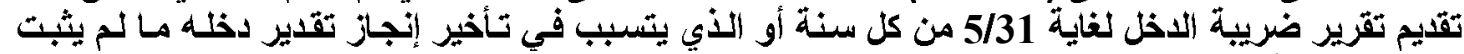

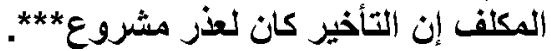

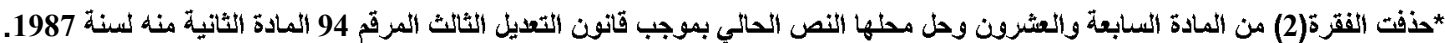

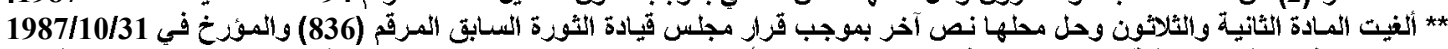

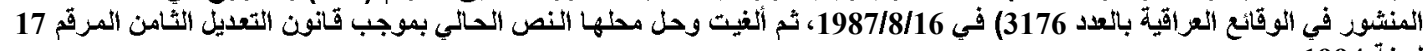


3- استخدام أسلوب العينات في تقدير ضريبة الاخل التل

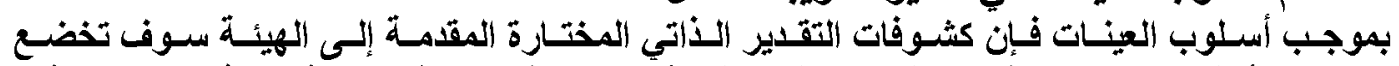

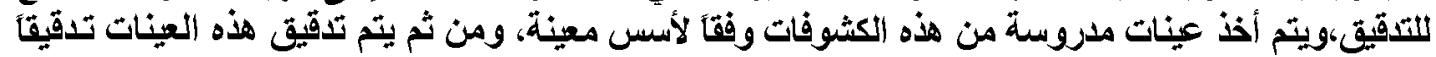

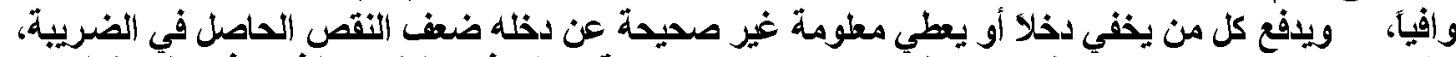

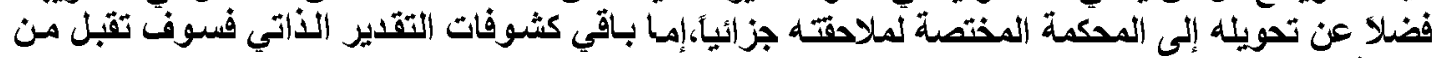

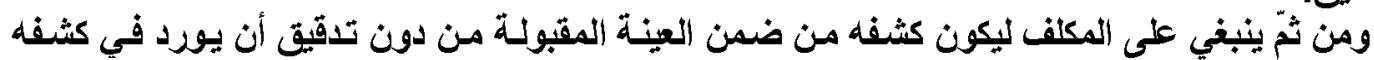

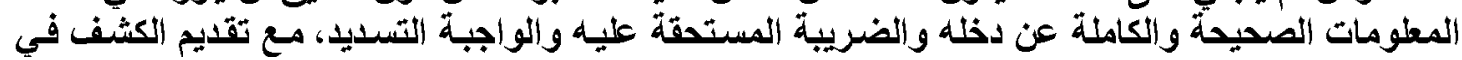
الموعد المحدل قاتوناً)

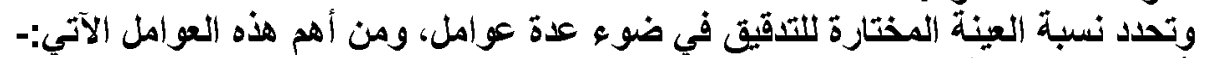

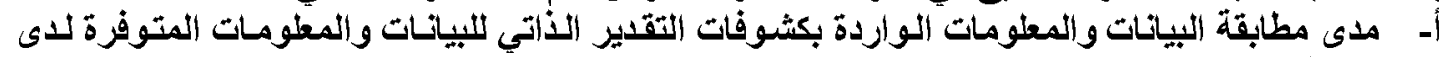

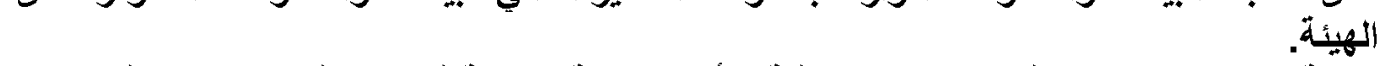

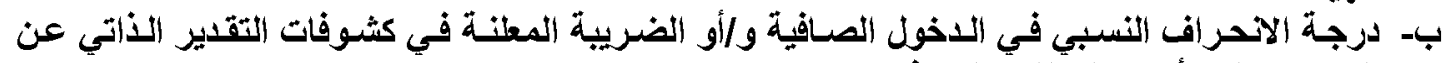
الضر ائب التي أعتاد المكلف على دفعها.

وتعد كثوفات التقدير الأتي للمكلفين الذين لم ترد كشوفهم ضمن العينات المختارة للتدقيق مقبولة

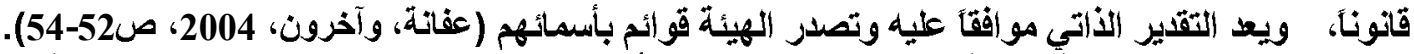

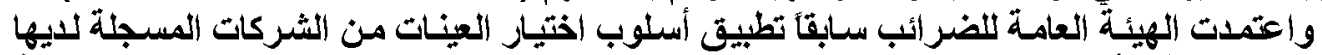

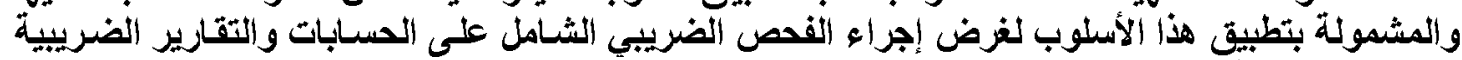

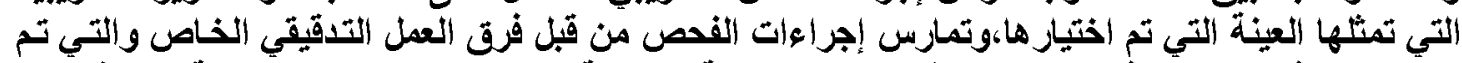

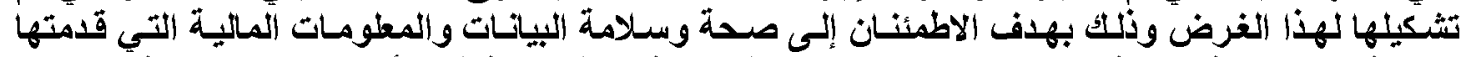

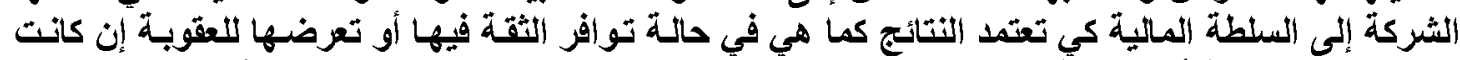

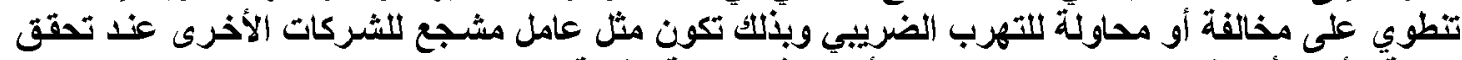

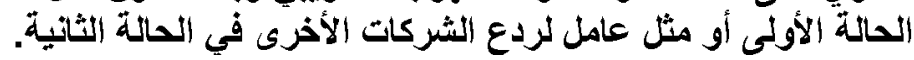

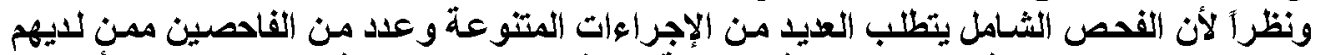

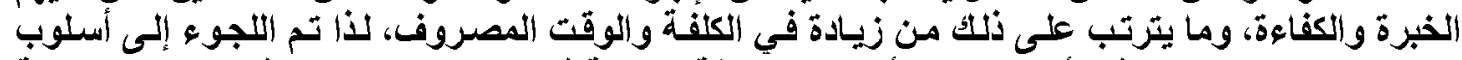

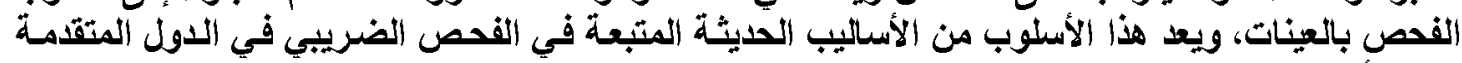

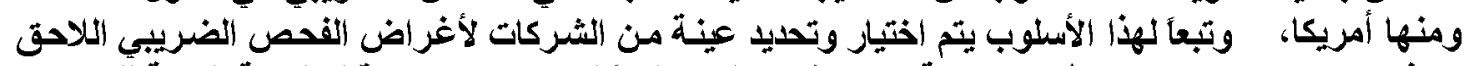

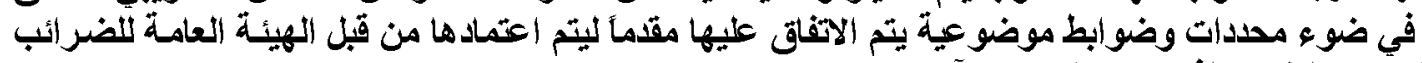

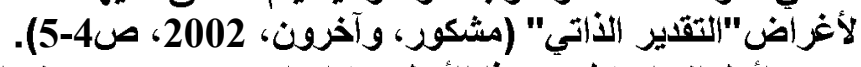

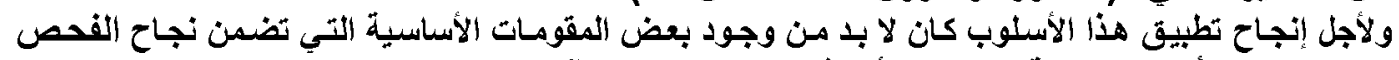

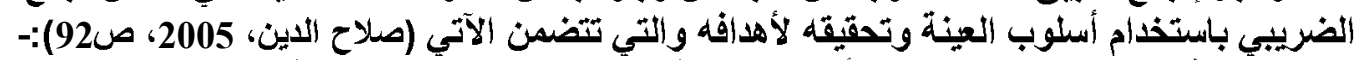

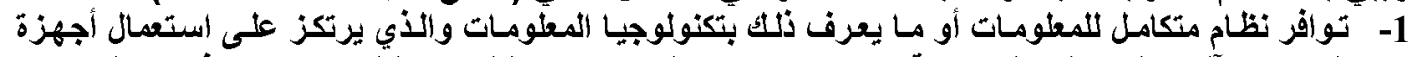

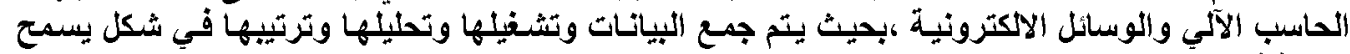
باتخاذ قرار حولها.

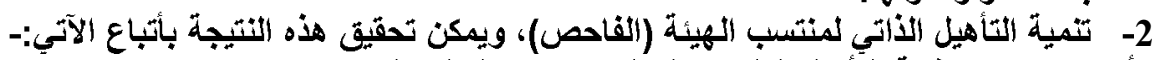

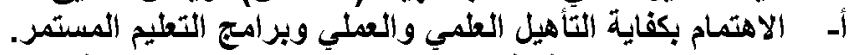

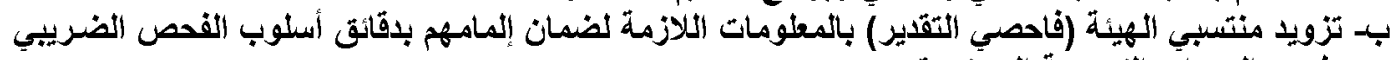
عن طريق الدورات التذريبية المستمرة.

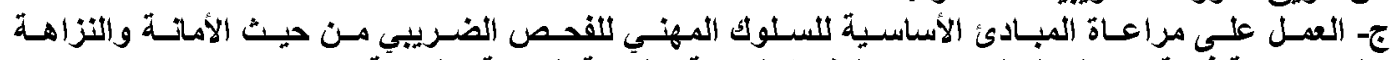

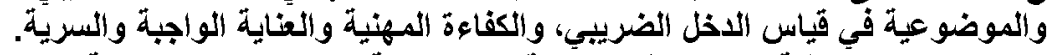

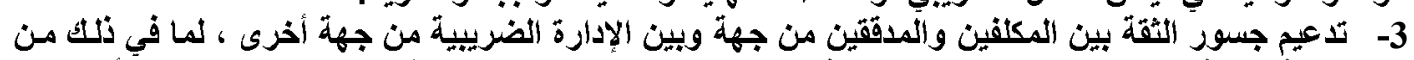

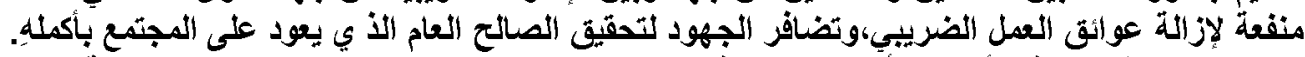

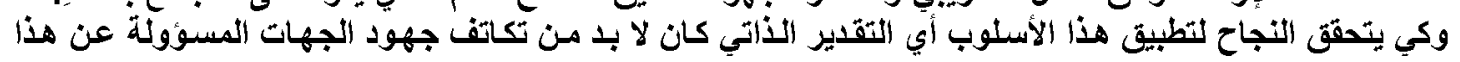

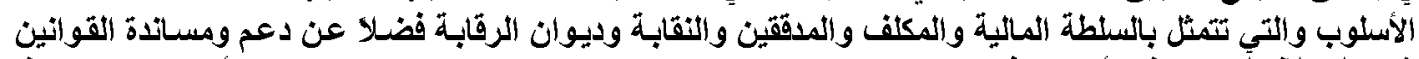

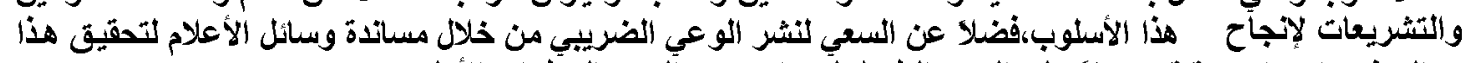

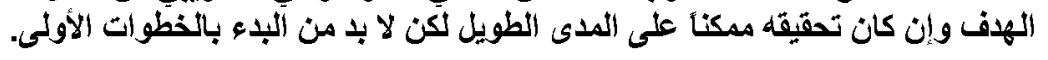




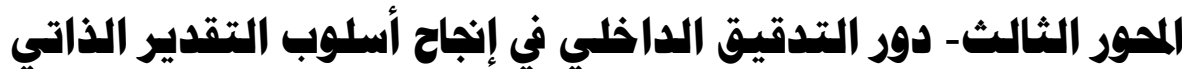

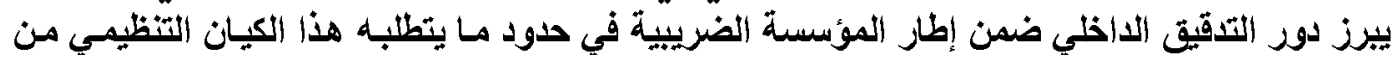

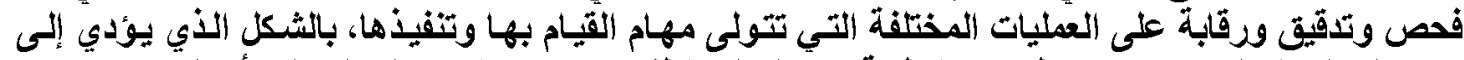

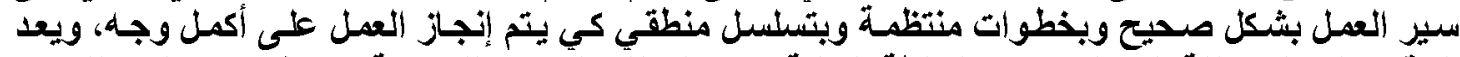

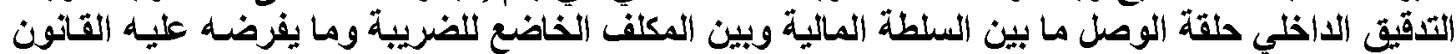

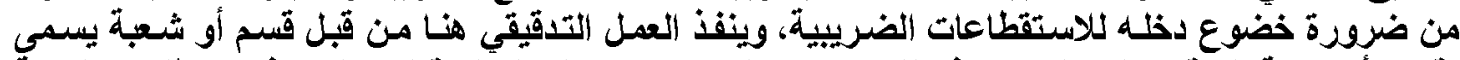

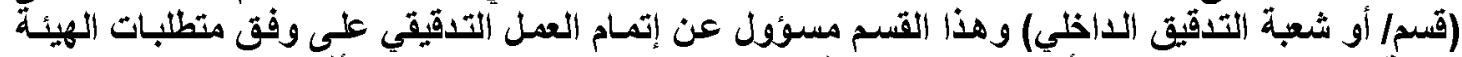

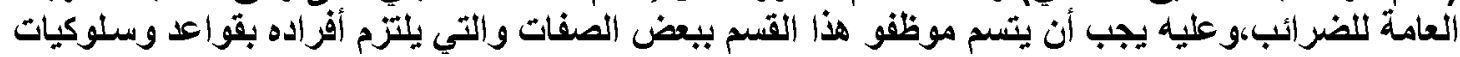

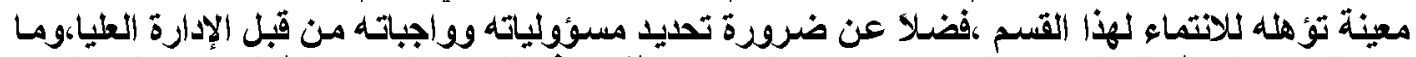

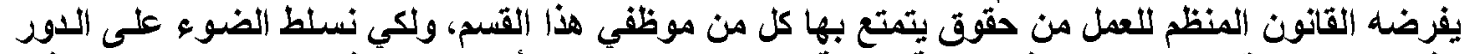

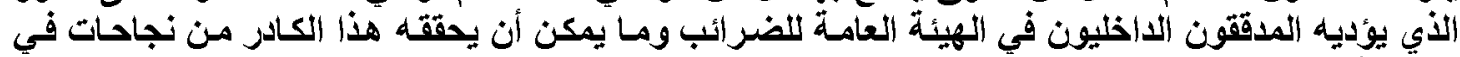

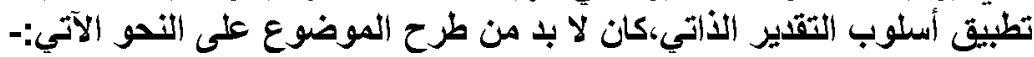

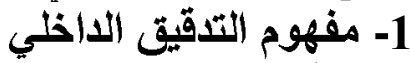

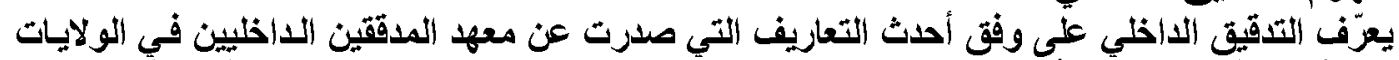

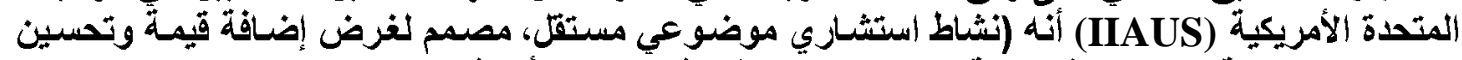

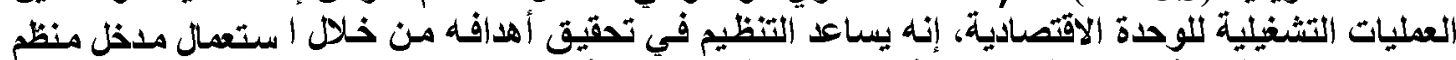

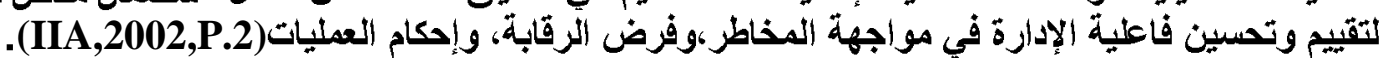

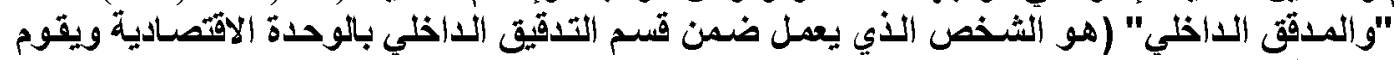

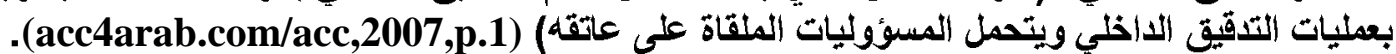

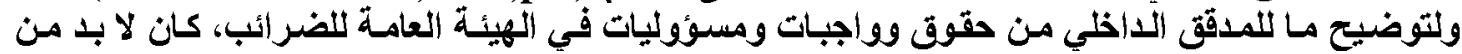

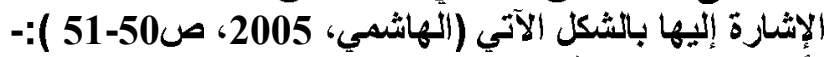

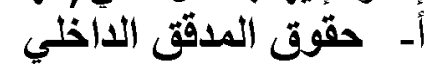

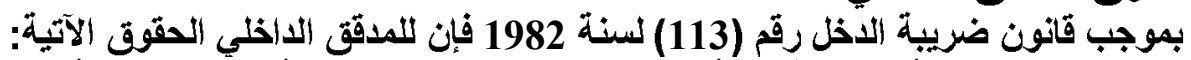

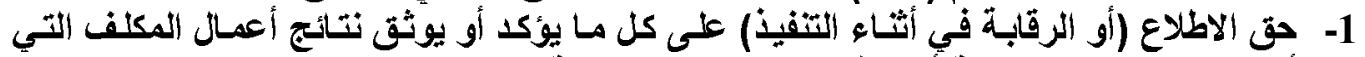

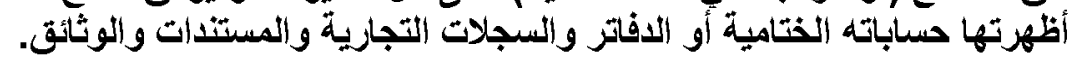

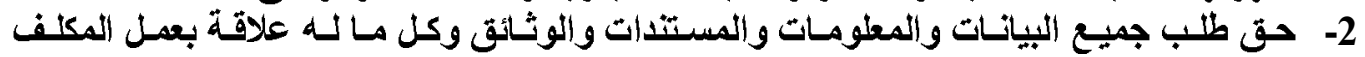

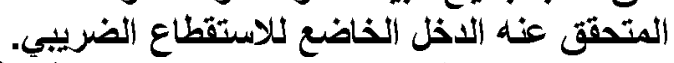

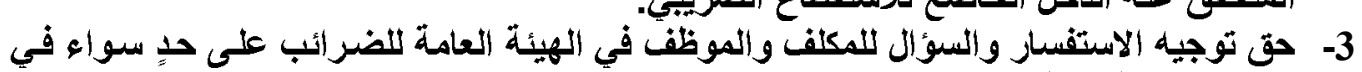
كل ما له صلة بآلية التحاسب الضبر الضريبي.

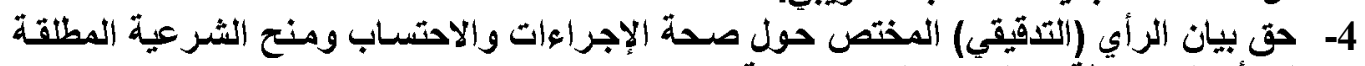

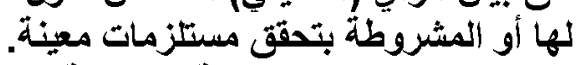

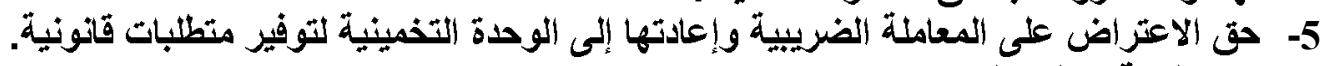

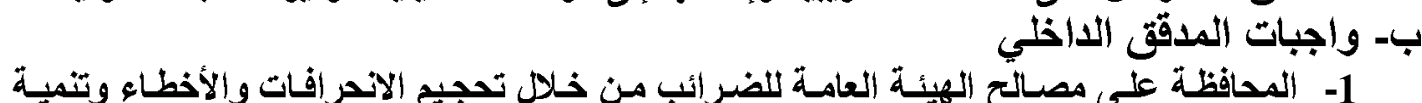
الإير ادات الضرائة الضيبية.

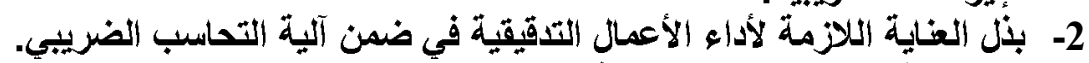

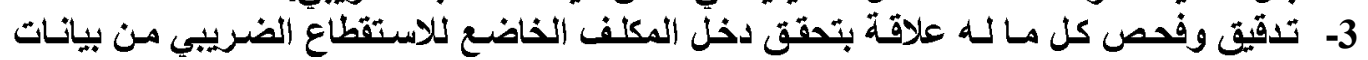

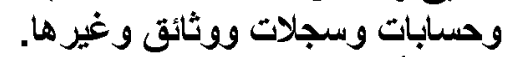

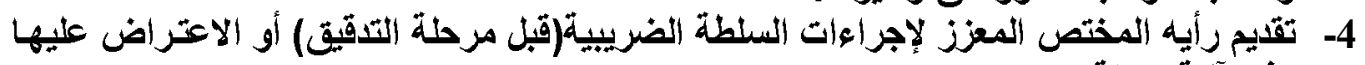
وفق آلية معينة.

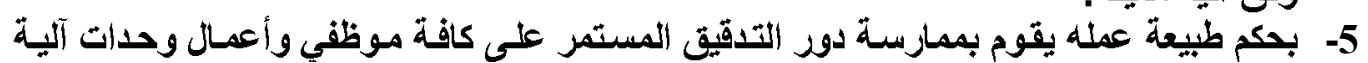

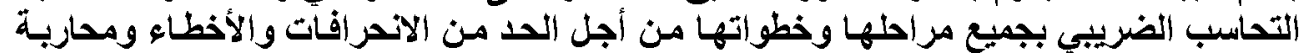
الفساد الإداري. 
ج- مسؤوليات المدقق الإخلي

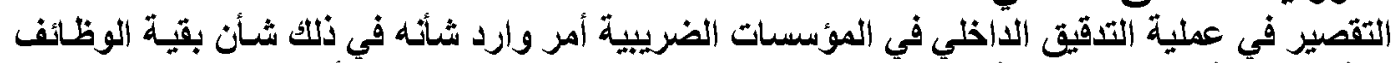

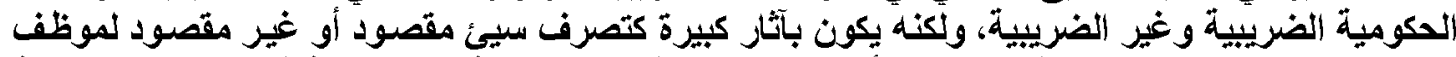

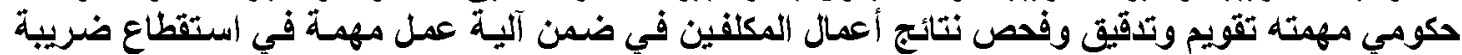

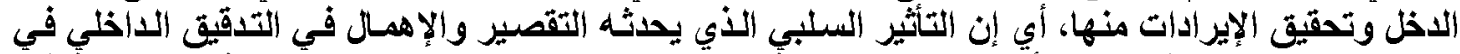

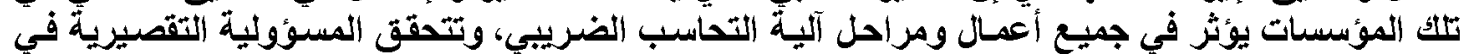

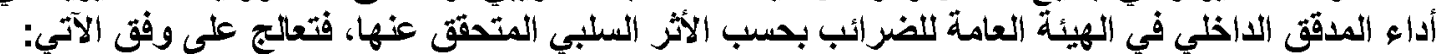

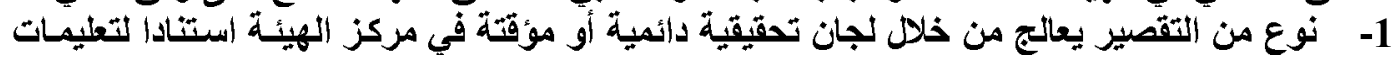
إدارية وصلاحيات معينة.

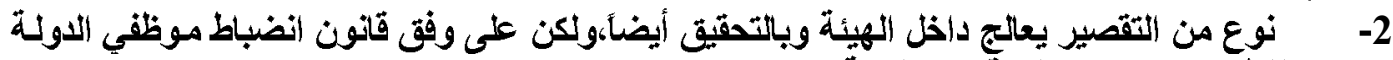

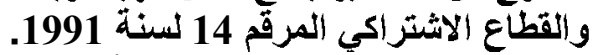

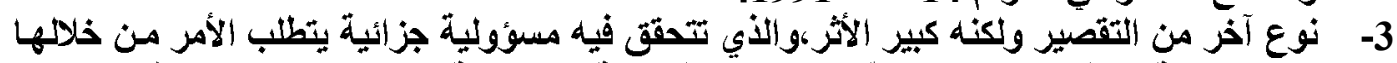

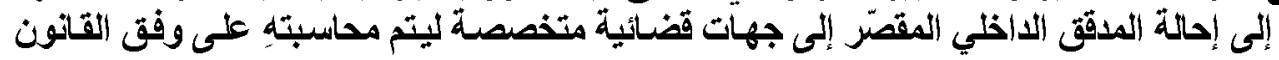

$$
\text { المدني. }
$$

$$
\text { د- أسلوب تنفيذ عمل المدقي الداخلي }
$$

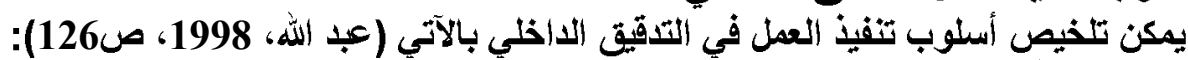

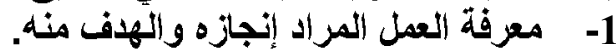

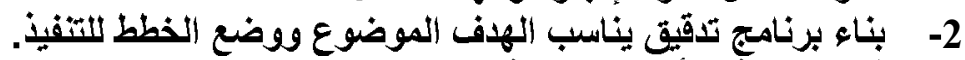
3 -

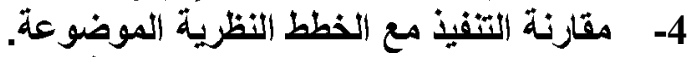
5- تقليم تقريز لمختلف المستويات الإدارية المعنية عن الإنجازات والفروقات وأسبابها وطرائق حل

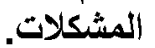

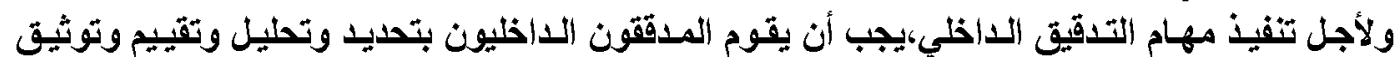

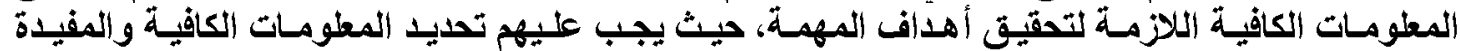

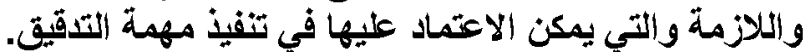

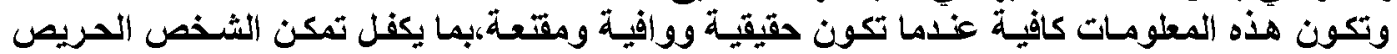

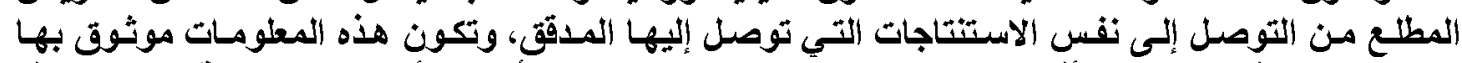

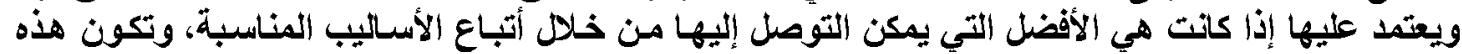

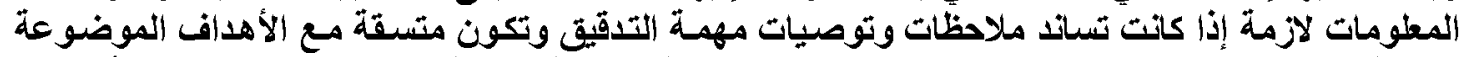

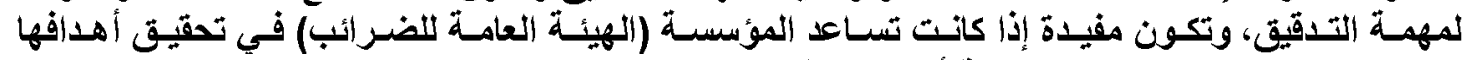

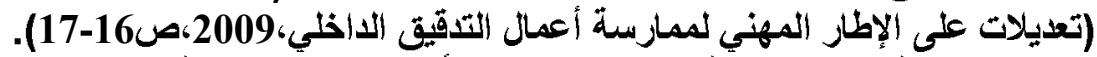

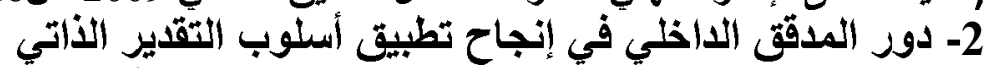

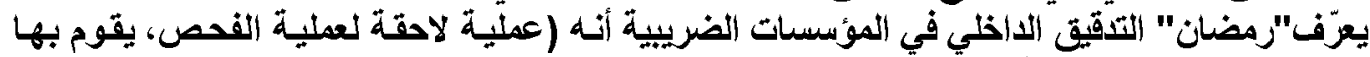

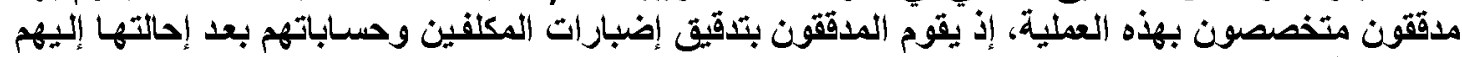
بعد عملية فحصها).

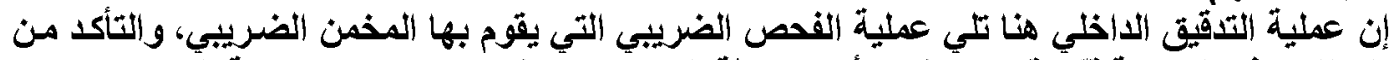

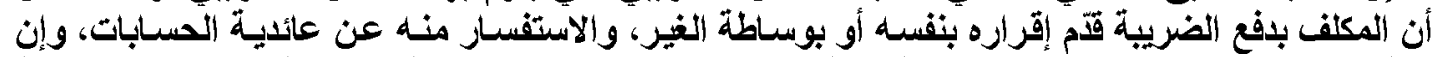

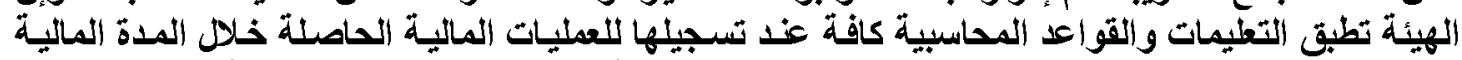

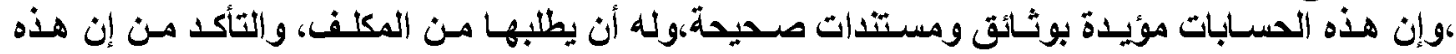

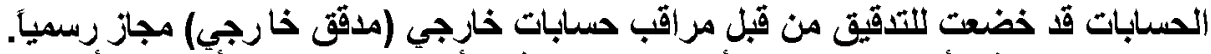

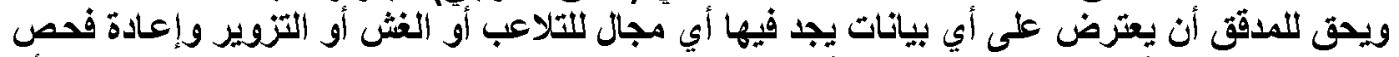

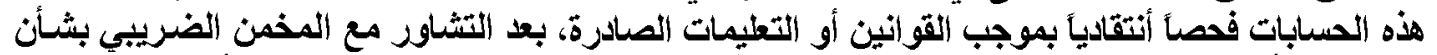

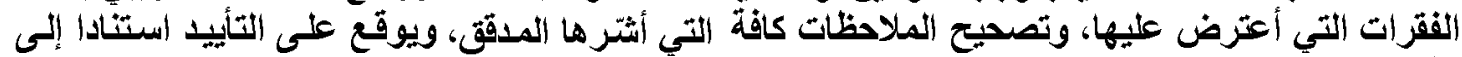




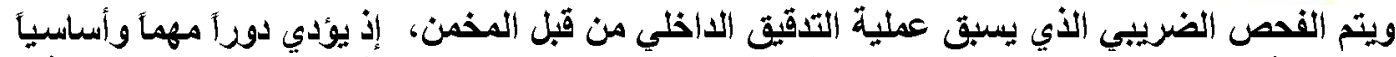

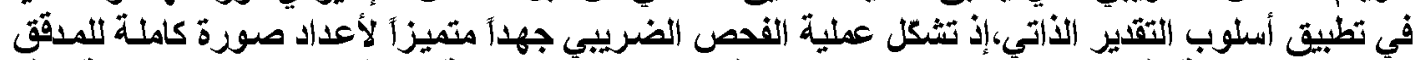

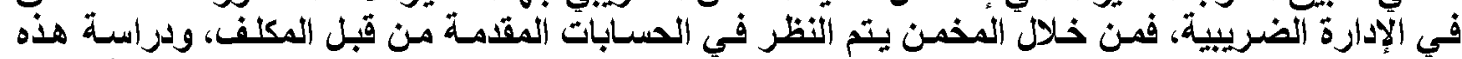

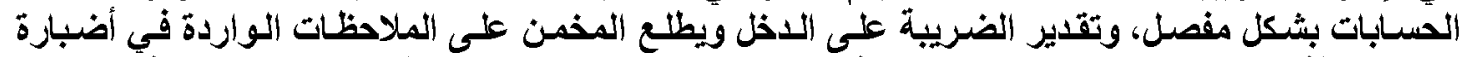

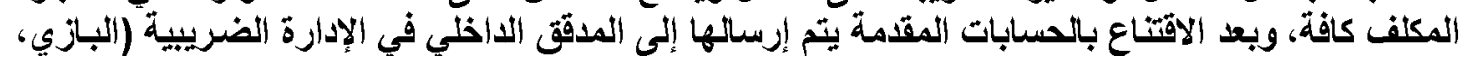

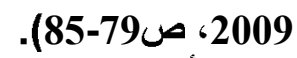

ولأجل توضيح الواجبات التي تقع على عاتق المخمن الضريبي عذ تطبيق هذا الأسلوب والآلية الخاصة

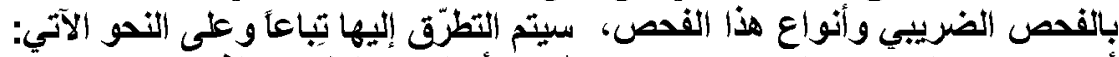

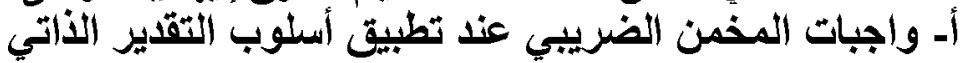

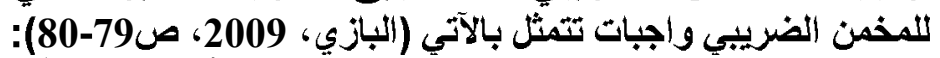

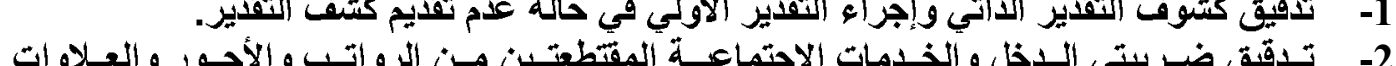

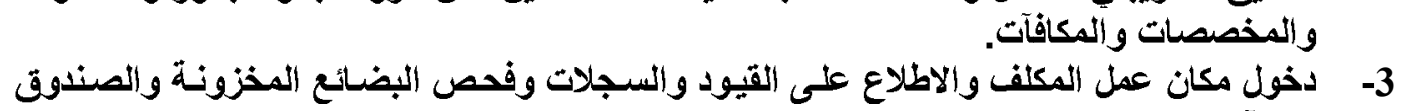

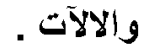
4- - الب المعلومات الضرورية التفيذ أحكام القانون.

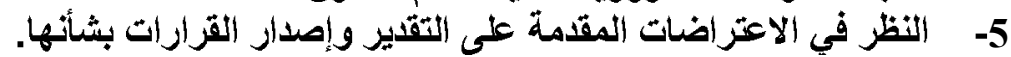

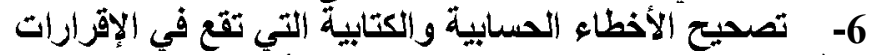

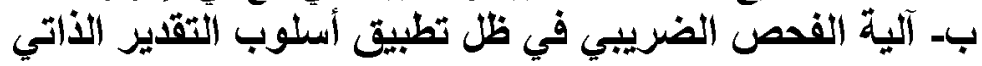

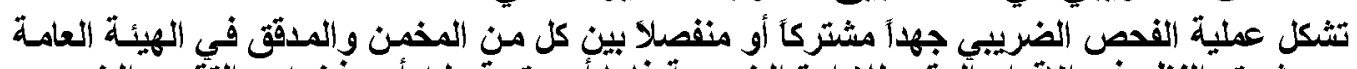

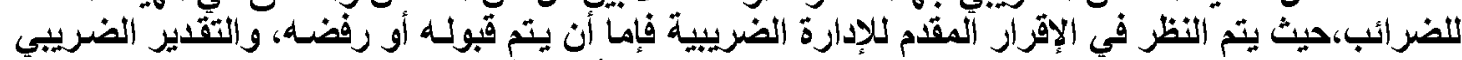

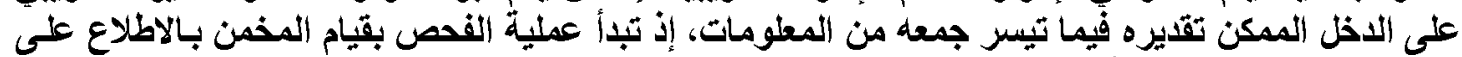

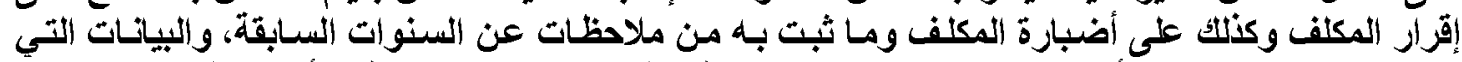

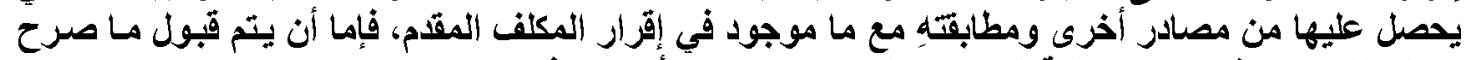

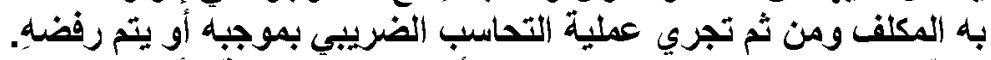

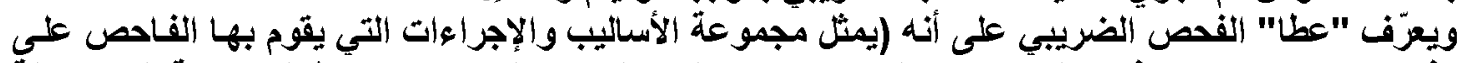

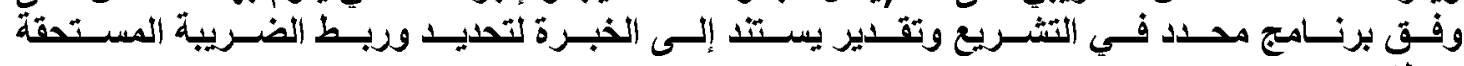

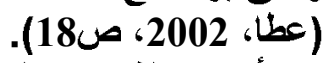

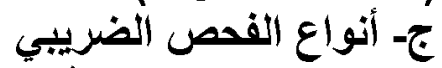

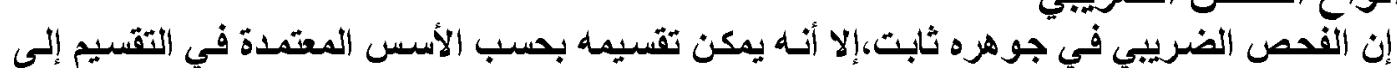

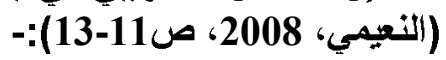

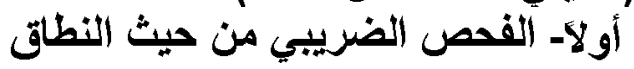

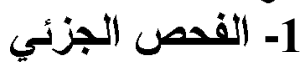

ويقصد به قيام ألفاحص الضير الفيبي بفدص جزء معين من أنشطة الثركة وهنـا بقتصر عمل ومسؤولية

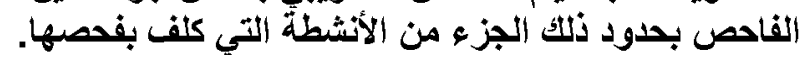

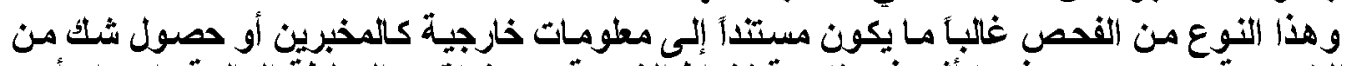

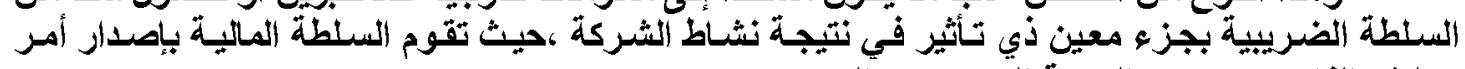

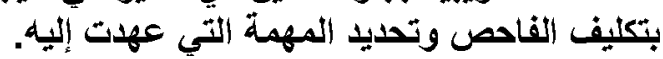

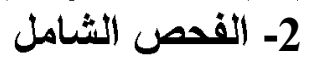

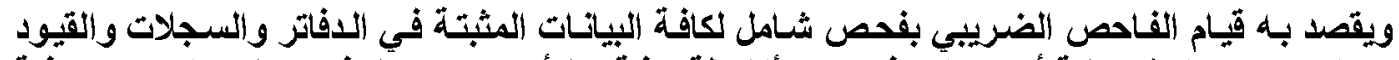

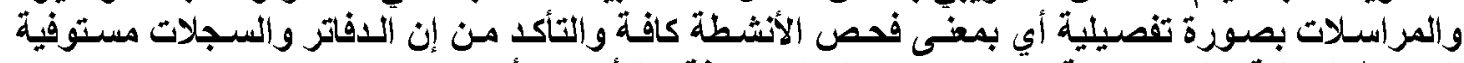

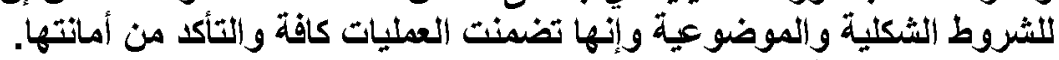

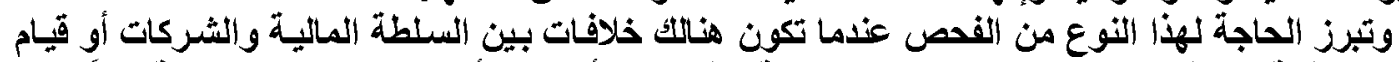

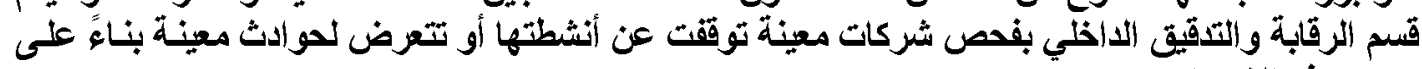
طلب من هذه الشركات. 


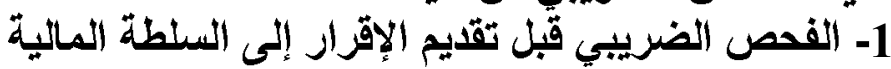

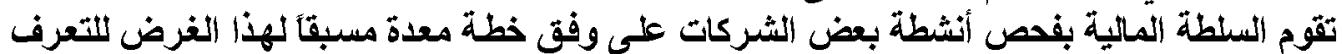

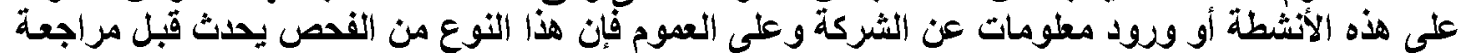

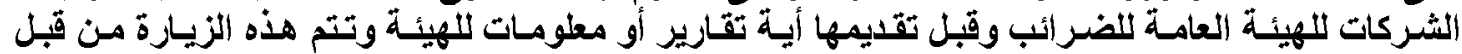

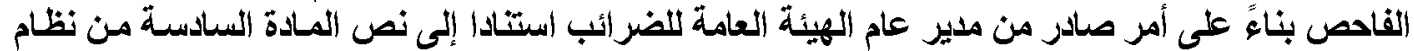

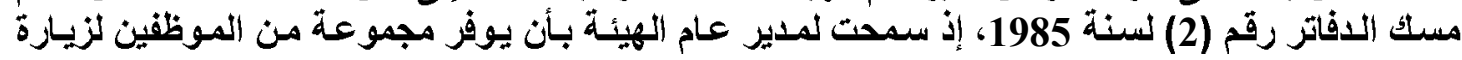

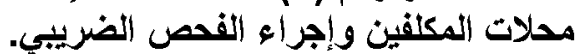

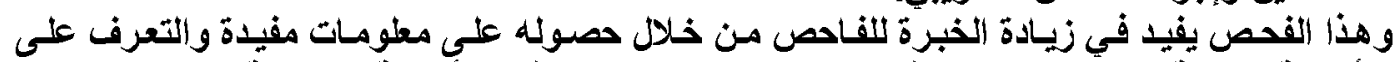

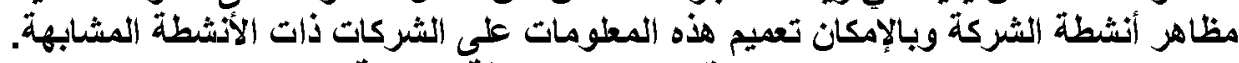

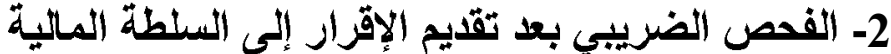

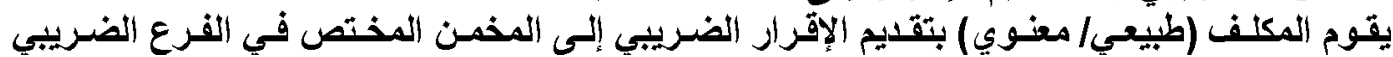

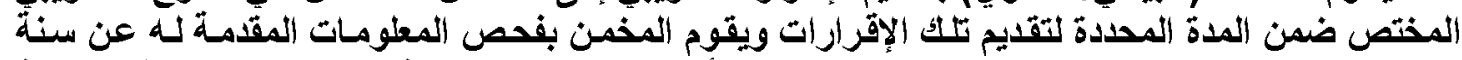

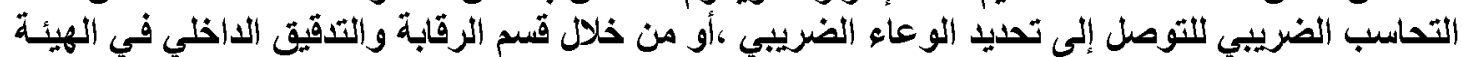

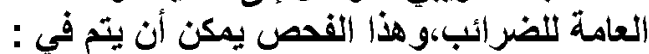

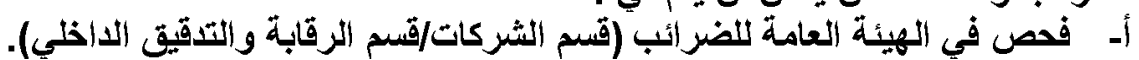

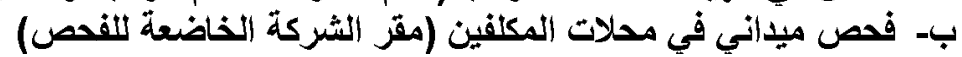

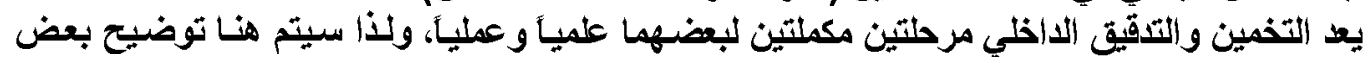

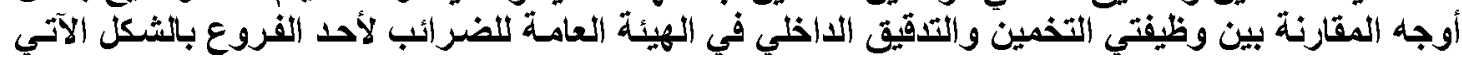

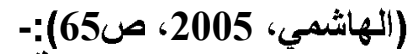
1- من حيث المسؤولية هنية

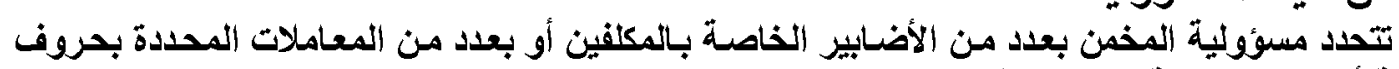

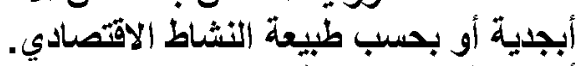

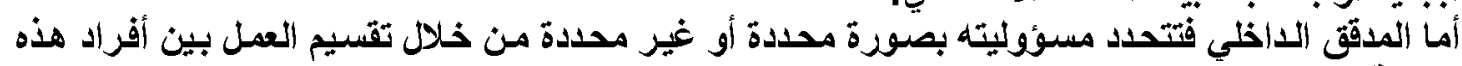

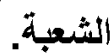

2- 2 من حيث العدد

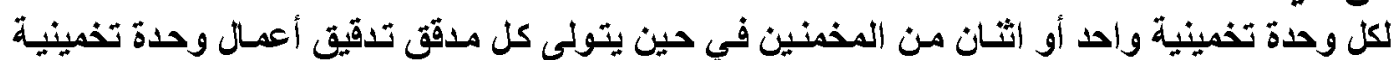

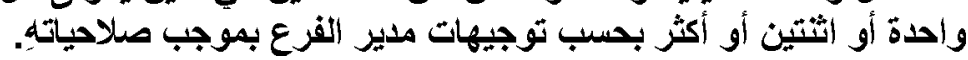

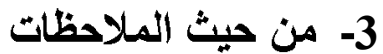

بتم الأخذ بالملاحظات كافة المطات التي يبليها المخمن أساسأ لتمشية المعاملة الضريبية

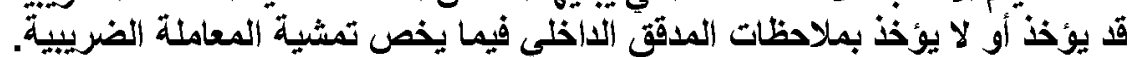

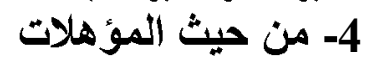

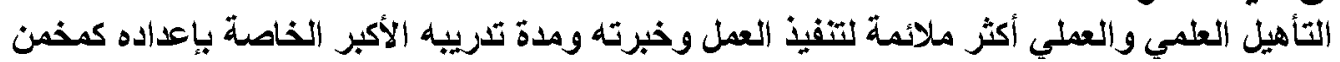

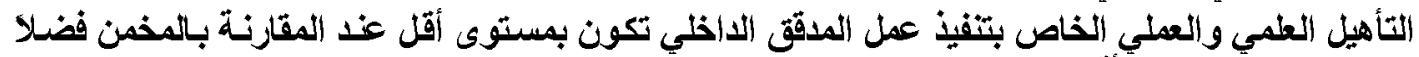

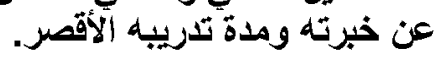
5- من فيث الاختيار

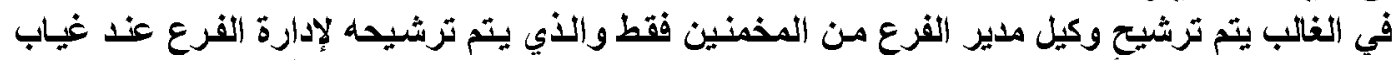

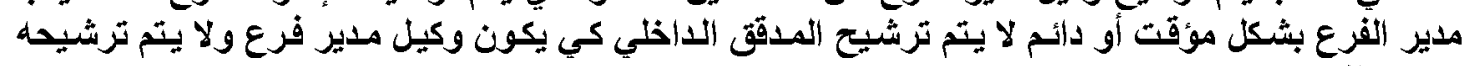

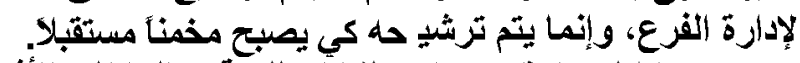

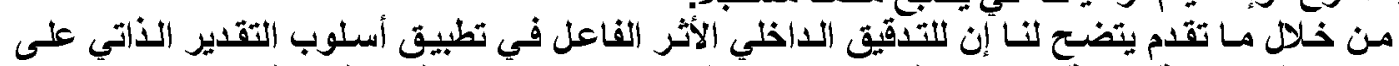

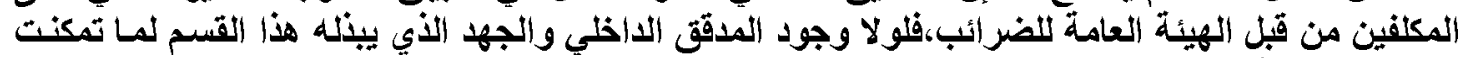

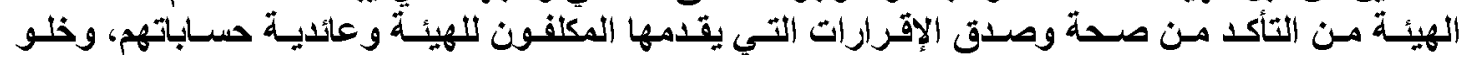
معاملاتهم من الغش والتلاعب والتزويز وكون تلك المعاملات تتفق مع القو انتين والتعليمات السائدة.

\section{المهور الرابع- دور التدقيق الفارجي في إنجاح أسلوب التقدير الذاتي}




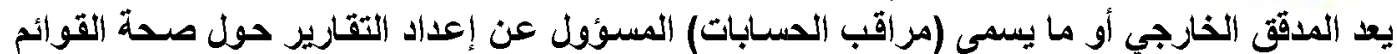

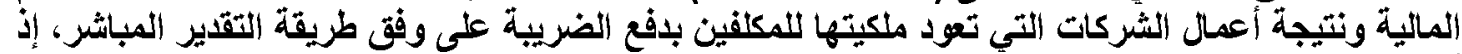

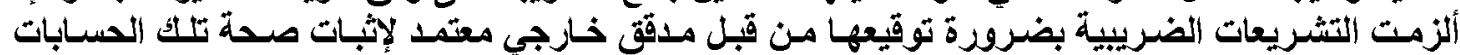

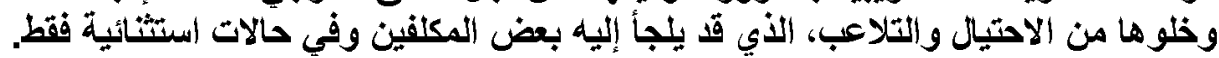

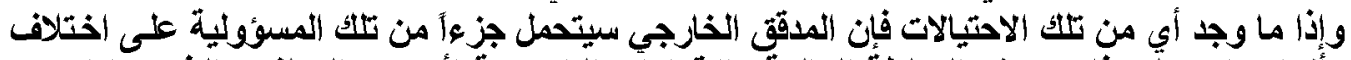

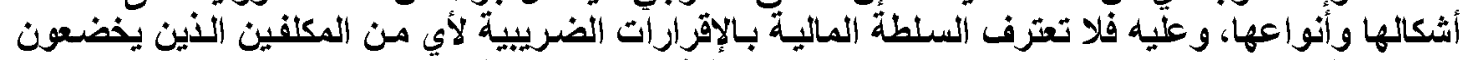

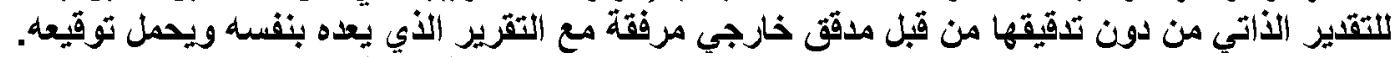

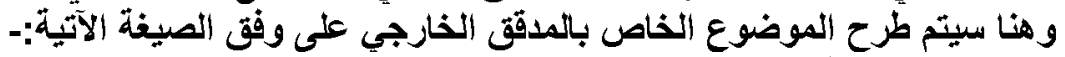

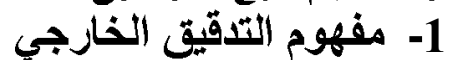

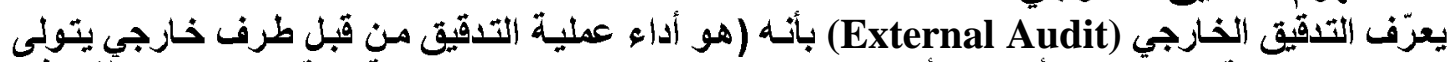

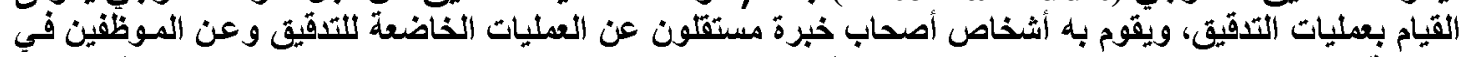

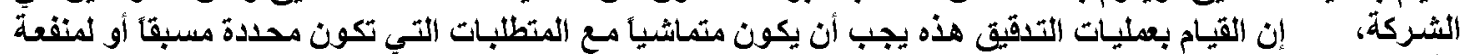

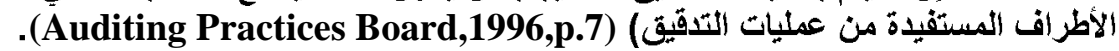

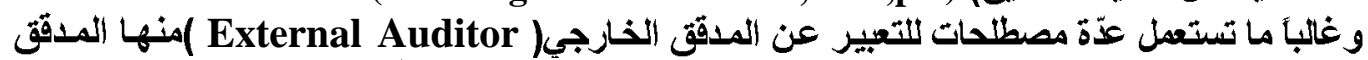

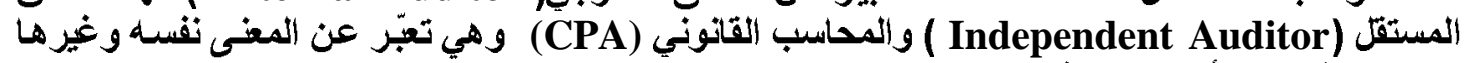
من المصطلحات الأخرى كمراقب الحسابات....الخ.

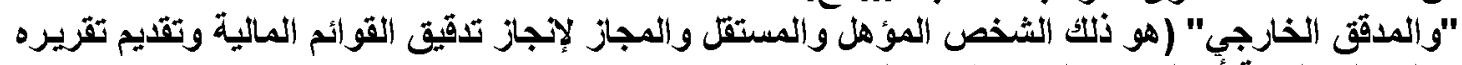

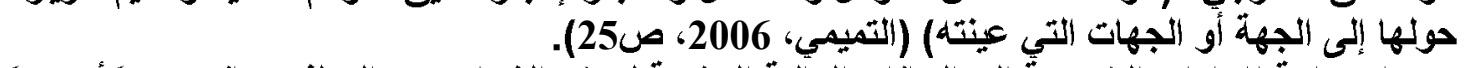

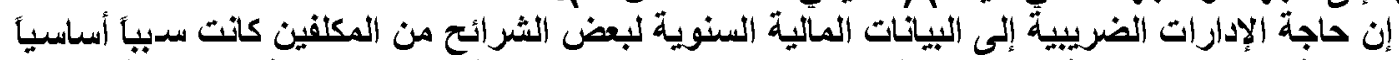

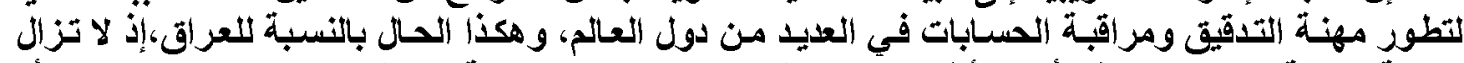

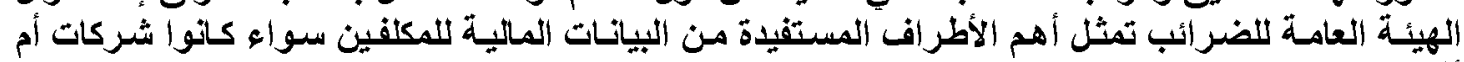

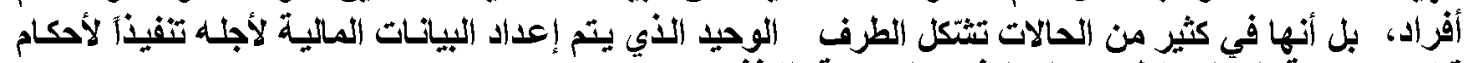

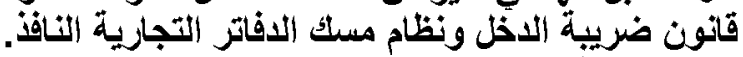

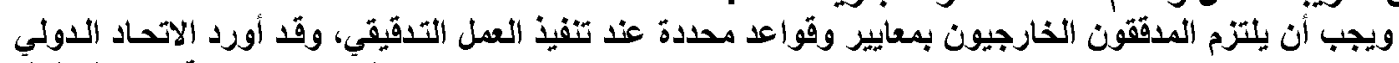

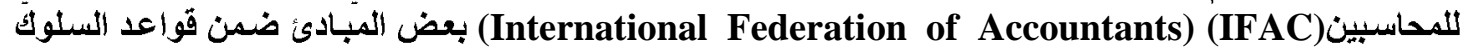

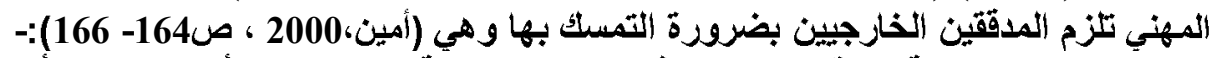

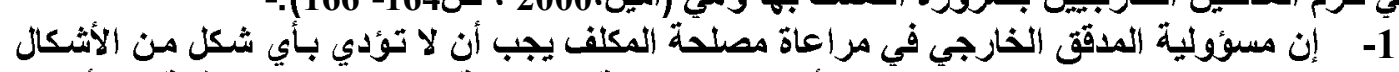

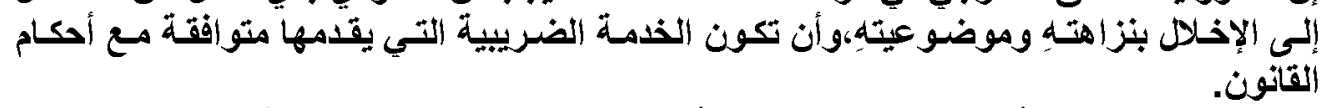

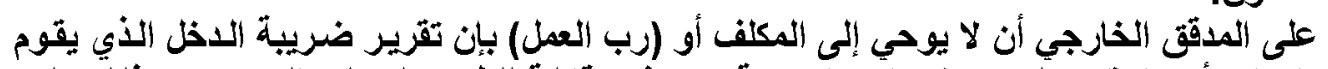

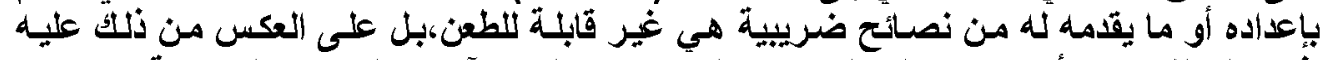

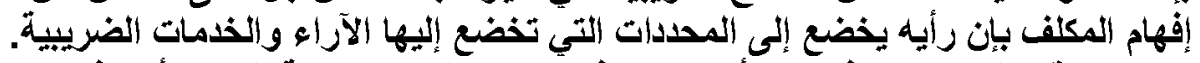

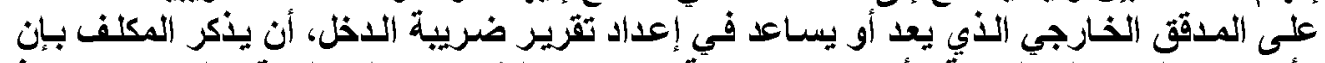

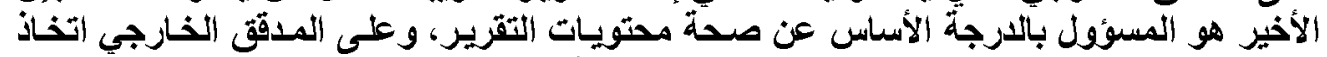

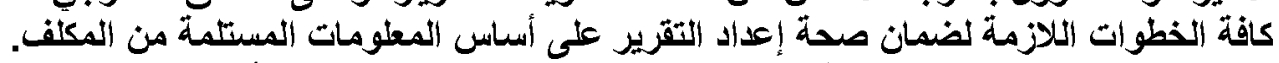

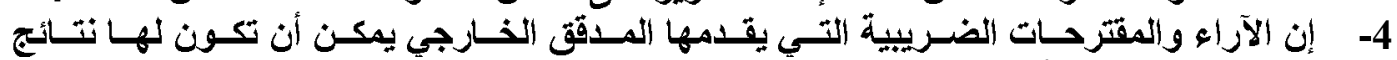
مهمة(مادية) ينبغي أن تقدم بصيغة مكتوبة الفيتية 


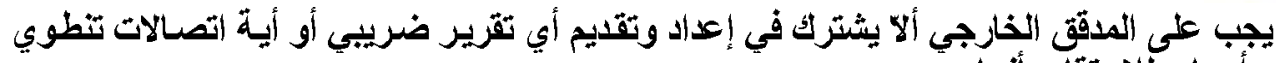

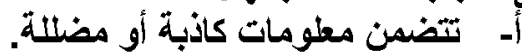

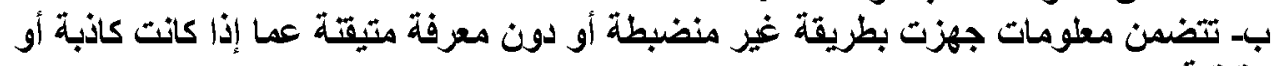

حقيقية.

ج- تضمنت حذف أو إخفاء معلومات كان مطلوب تقديمها وإن ذلك سيؤدي إلى

تضليل السلطات الضريبية.

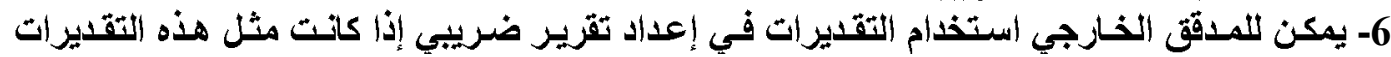

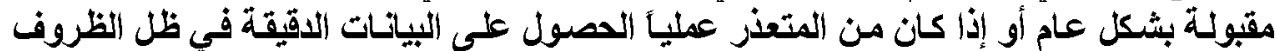

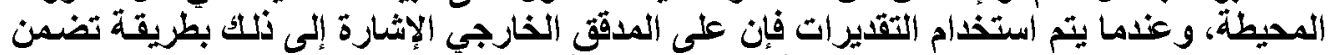

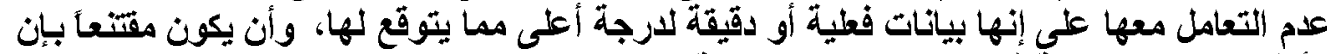

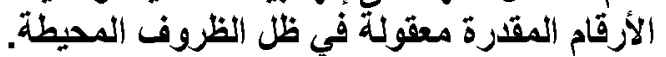

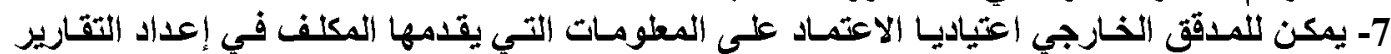

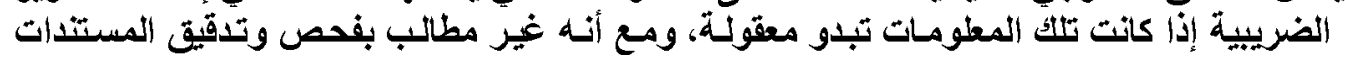

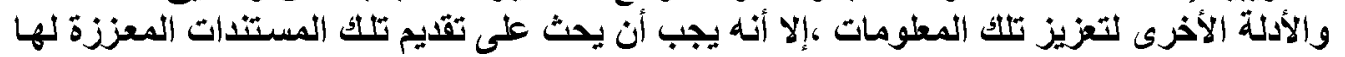

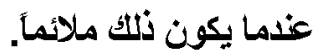
إن هناك علاقة وطيدة بين التذقيق والتقدير الأتي ولا سيما إن نجاح المدقق الخارجي في ضبطوتشقيق

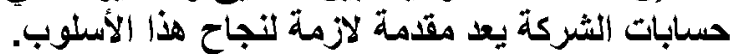

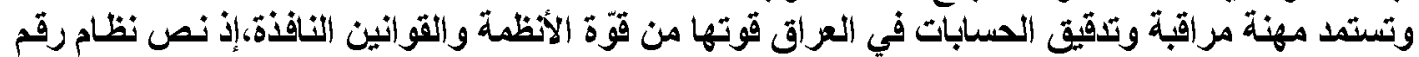

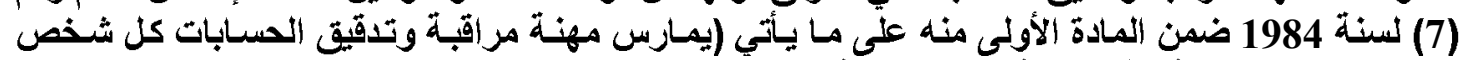

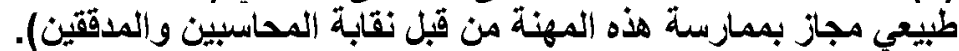

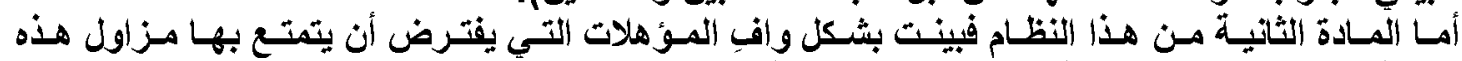

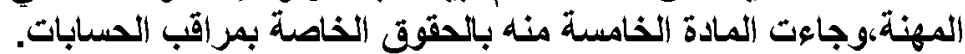

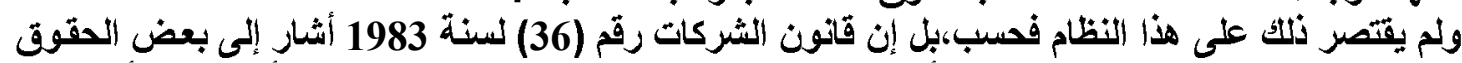

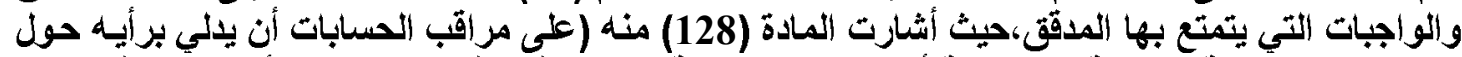

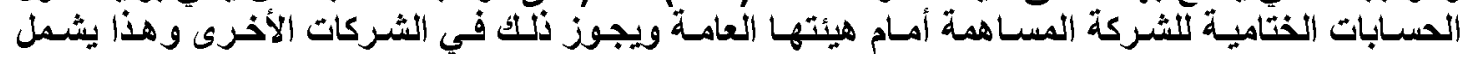

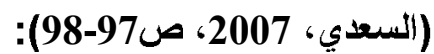

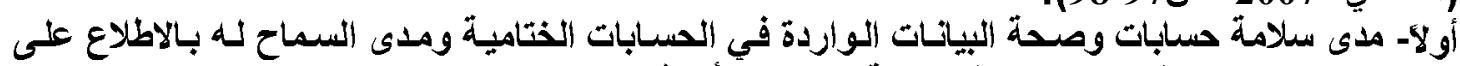

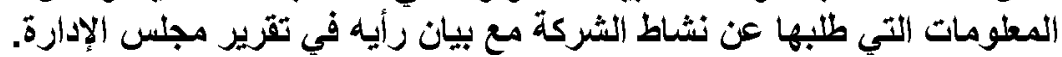

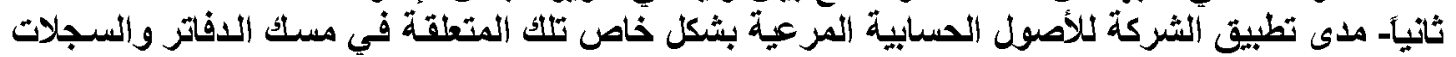

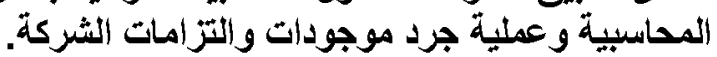

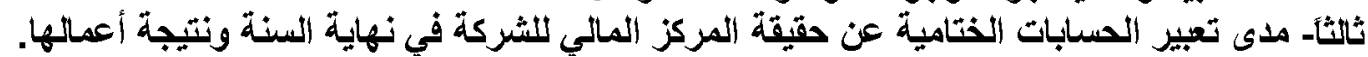

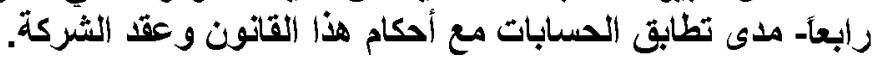

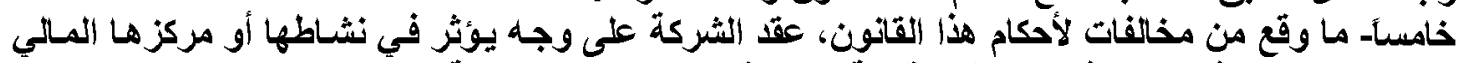

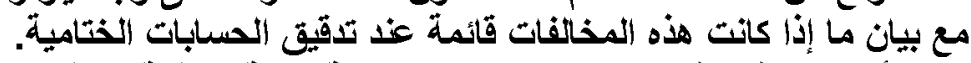

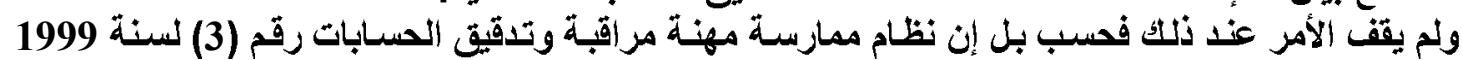

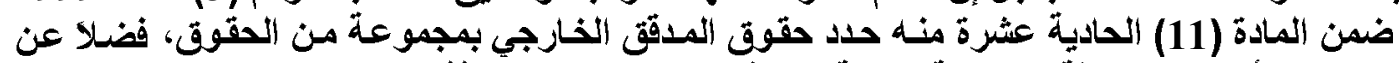

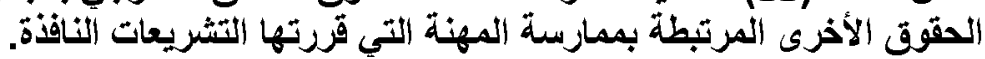




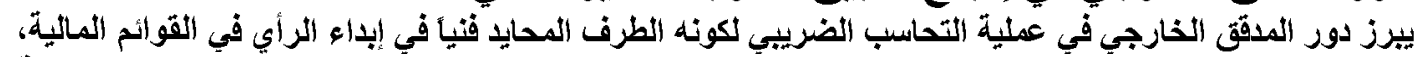

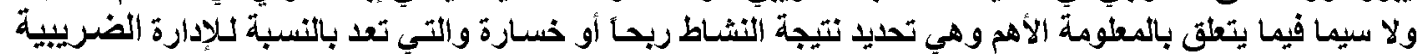

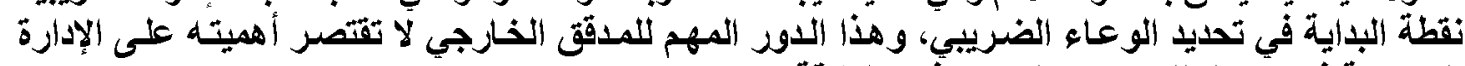

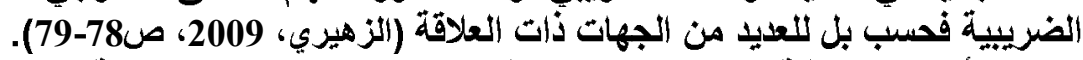

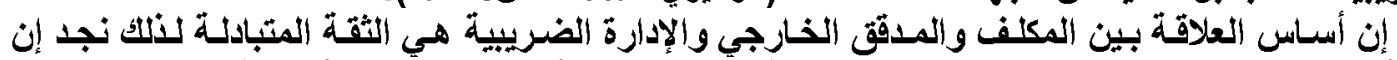

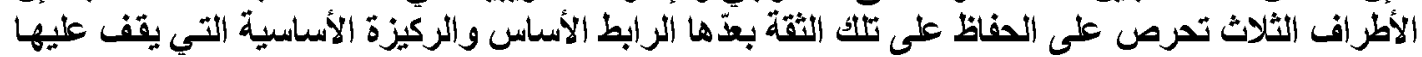

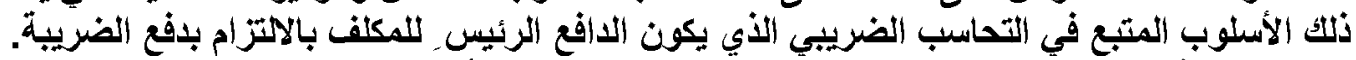

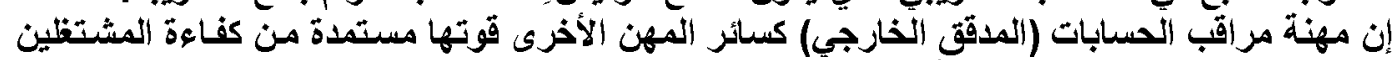

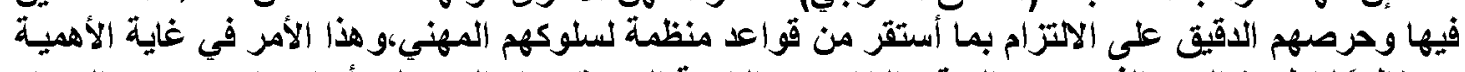

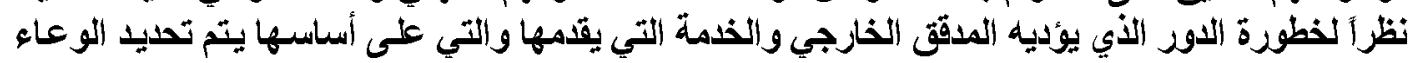

الضريبي.

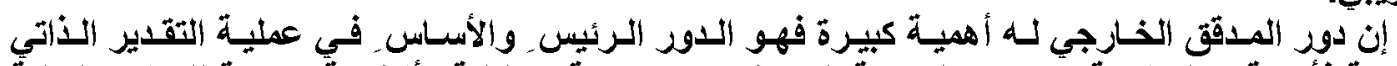

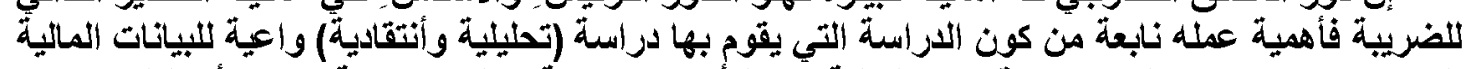

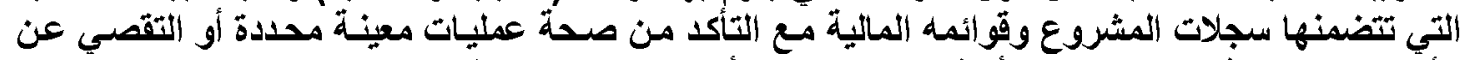

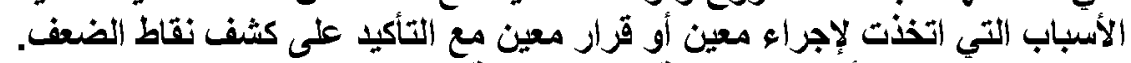

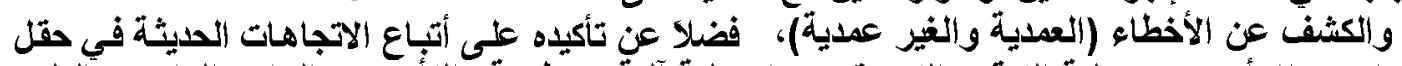

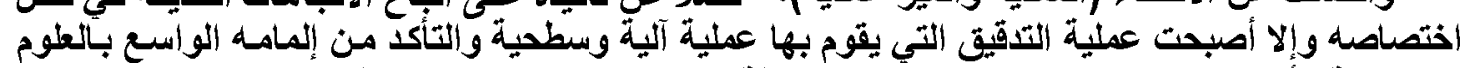

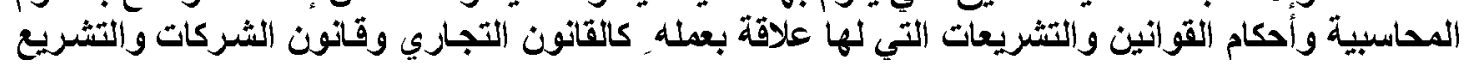

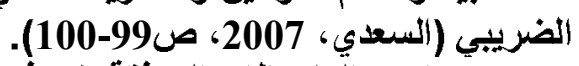

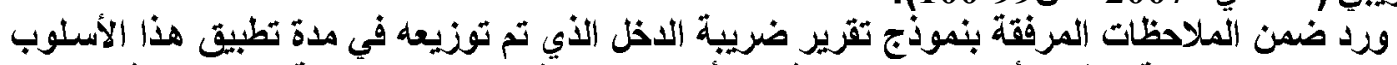

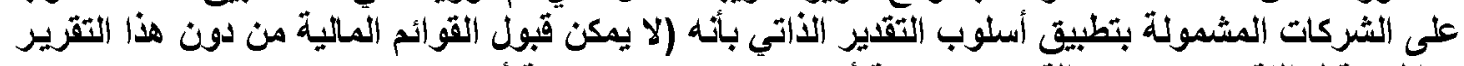

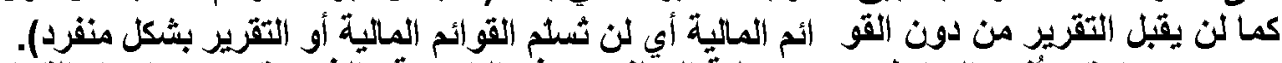

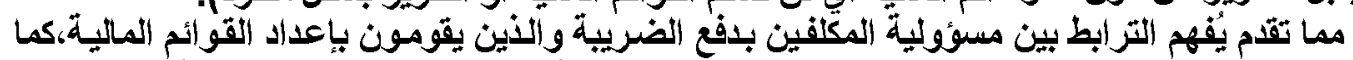

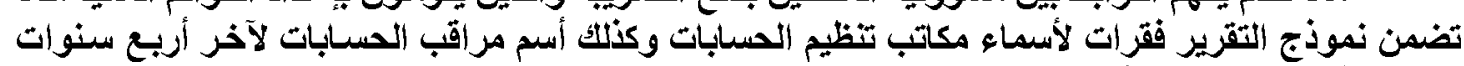

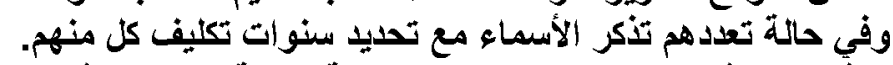

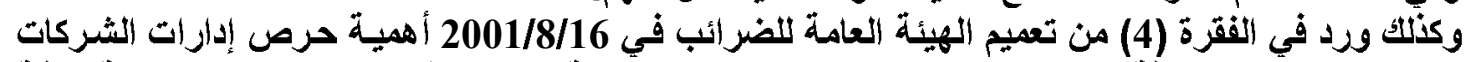

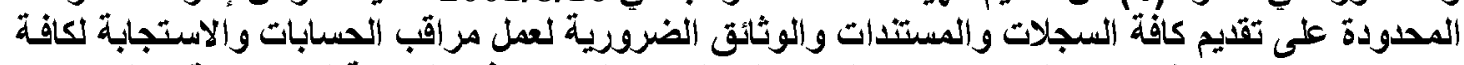

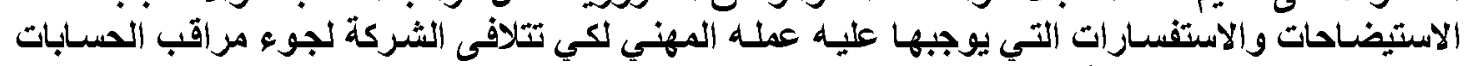

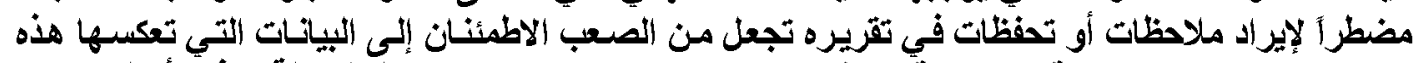

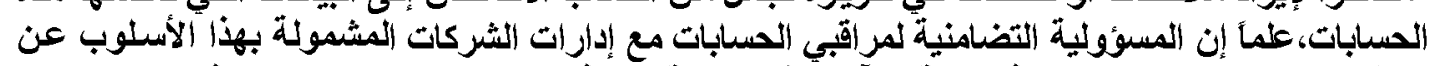

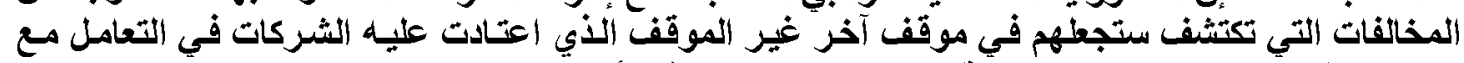

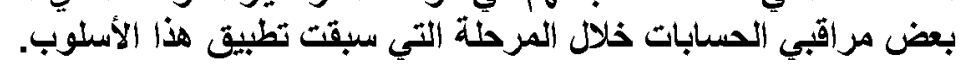

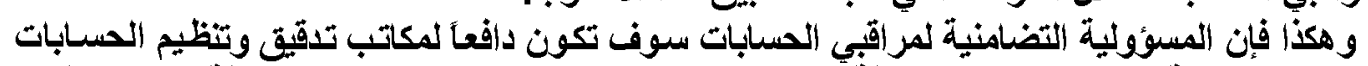

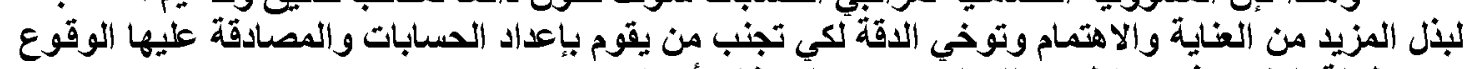

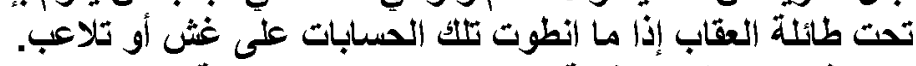

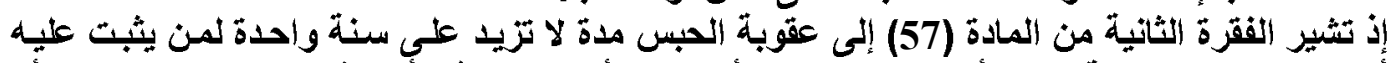

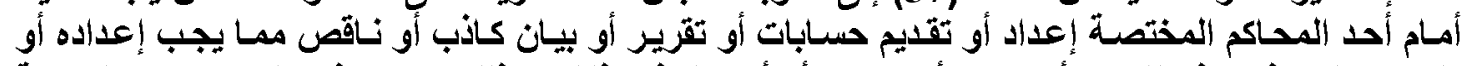

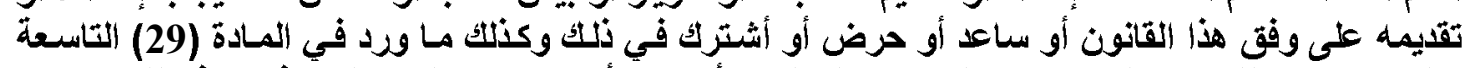

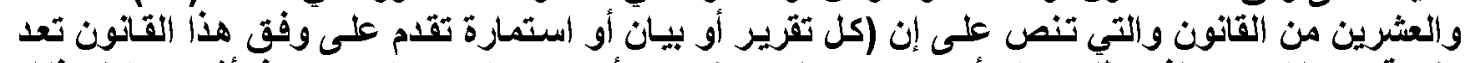

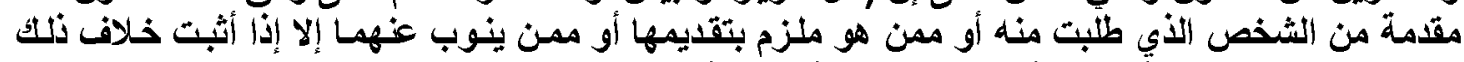

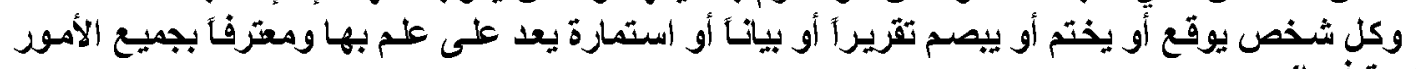




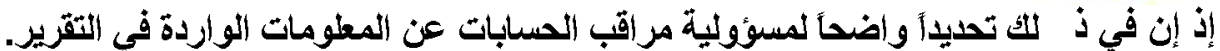

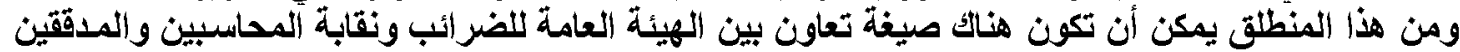

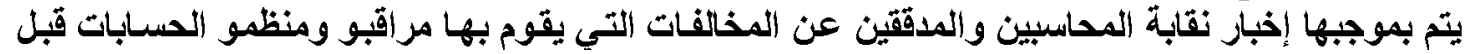

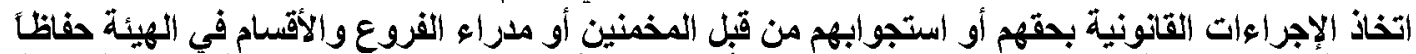

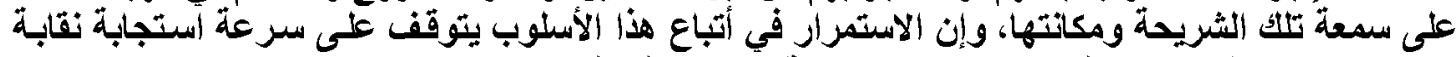

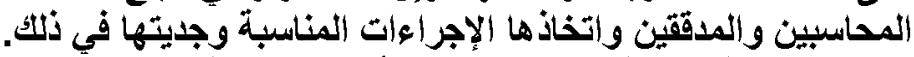

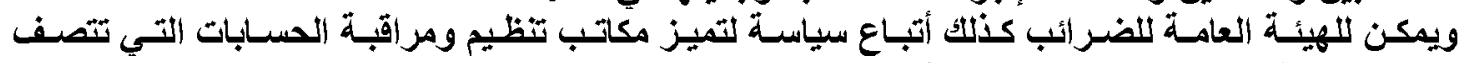

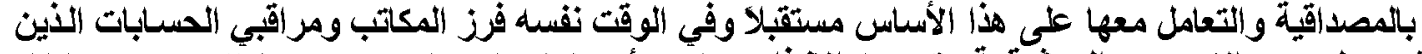

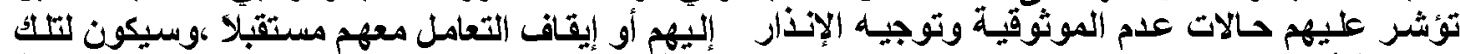

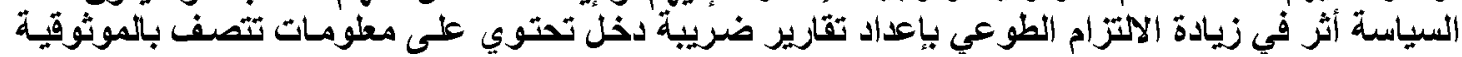

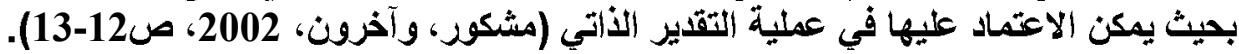

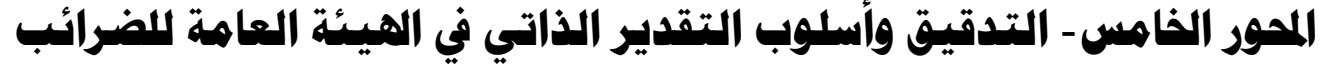

$$
\text { 1- تكامل عمل التدقيق الداخلي والخارجي }
$$

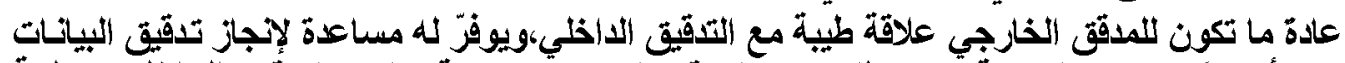

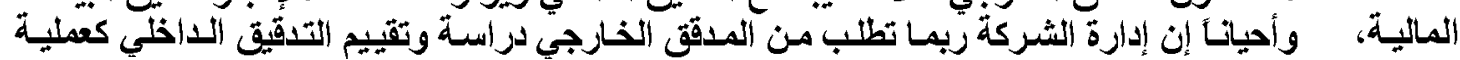

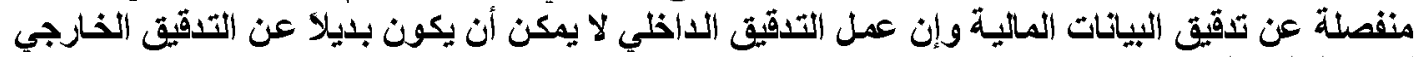

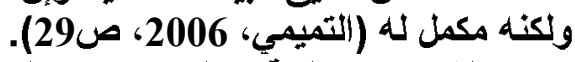

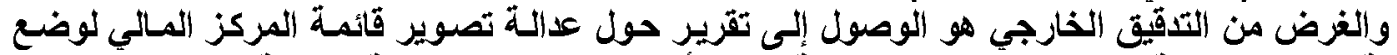

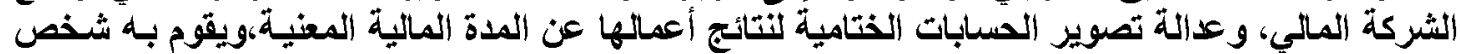

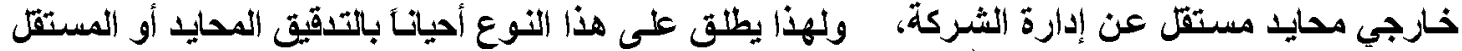
"Independent audit"

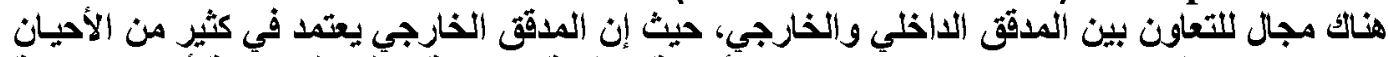

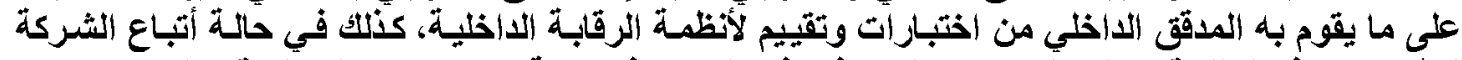

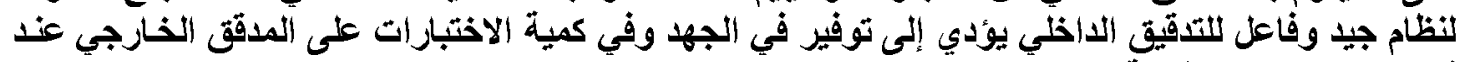

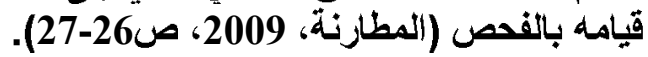

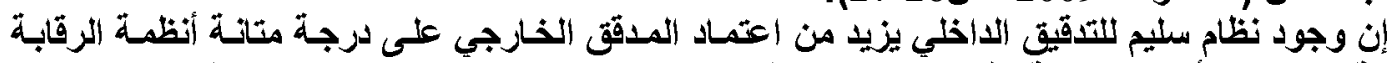

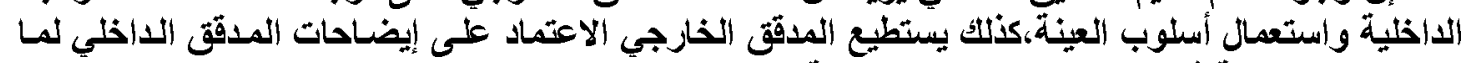

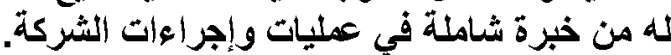

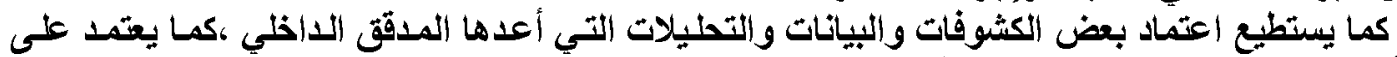

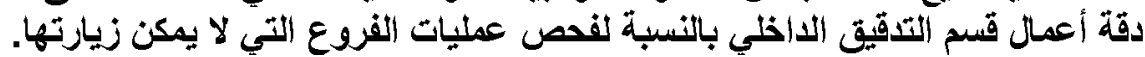

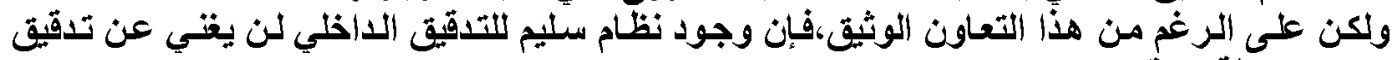
الحسابات بوساطة مراقب حسابات محايد.

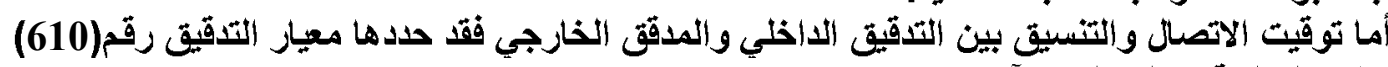
(مراعاة عمل التدقيت الأهاخلي بالآتي:-

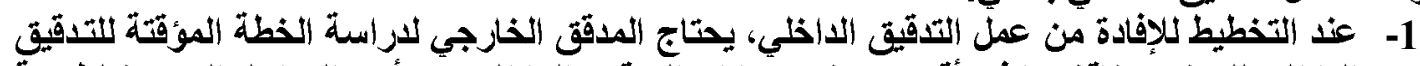

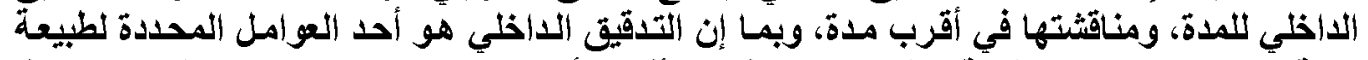

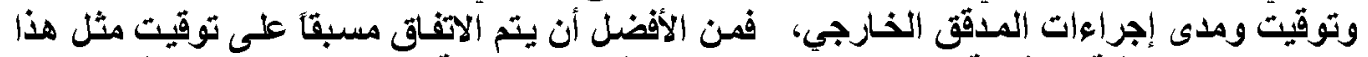

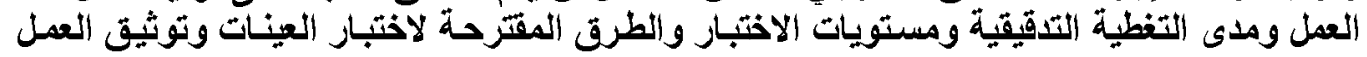

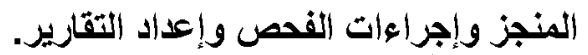

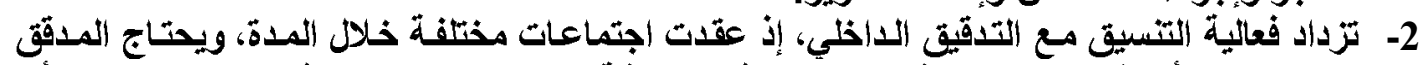

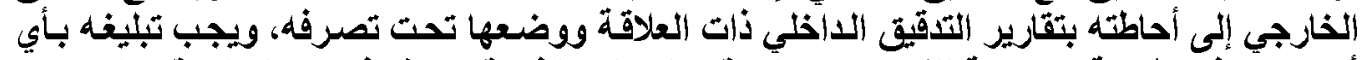

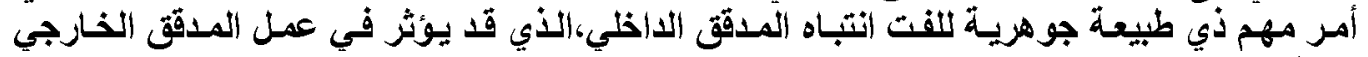
(نعيثل، 2009، صهم: (81-80). 


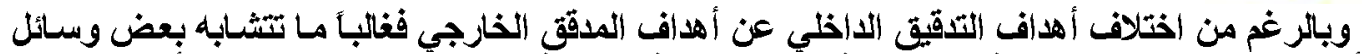

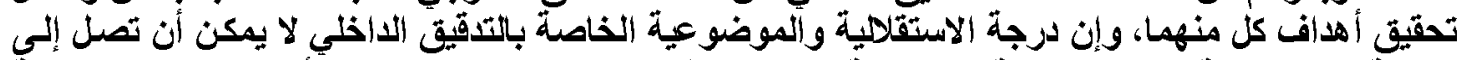

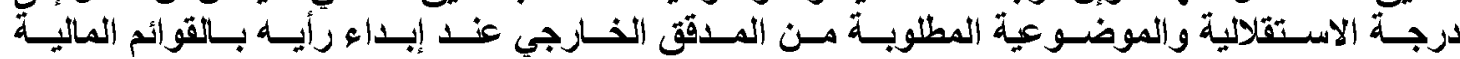

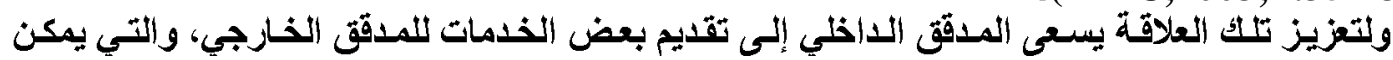
توضيحها بالآتي (الغربان، تلونة

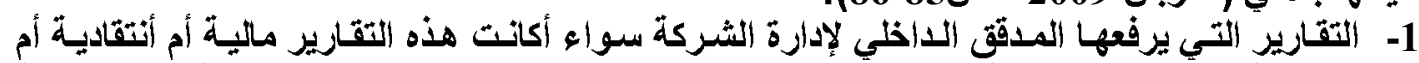

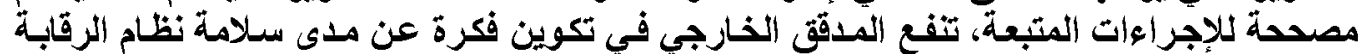

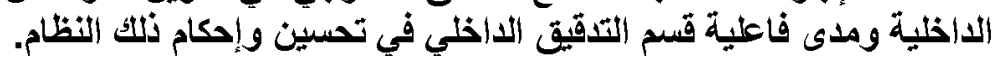

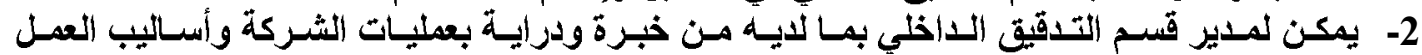
والإجراءات المتبعة في تثفيذ الأعمال،تقليم الإيضاحات الكاملة للمدقئ الخارجي في أثخاء قيامه بعلية

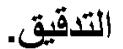

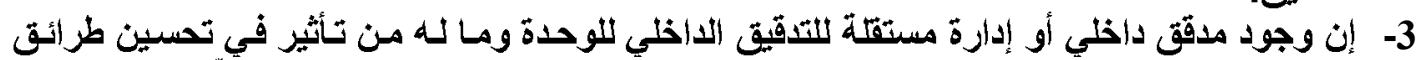

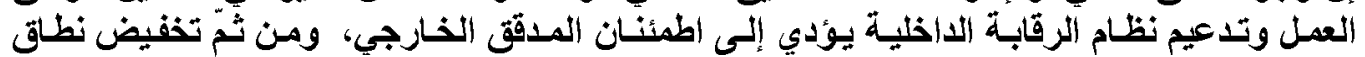

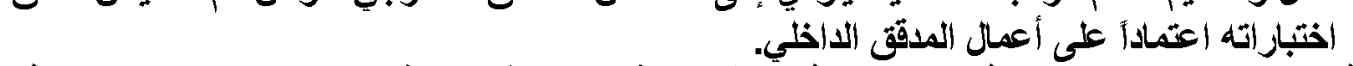

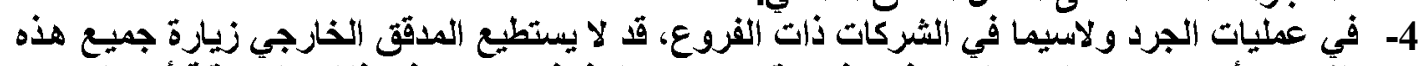

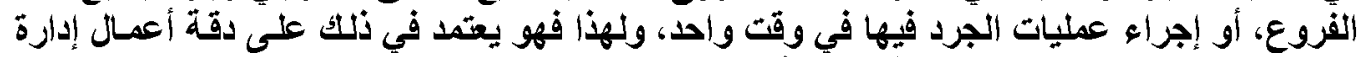

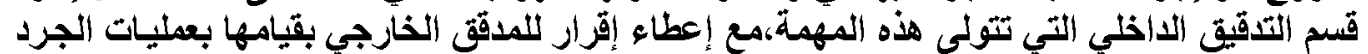

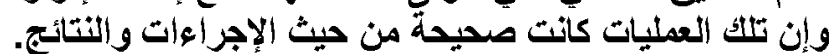

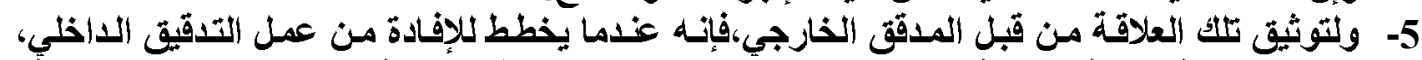

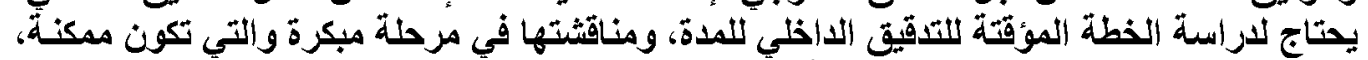

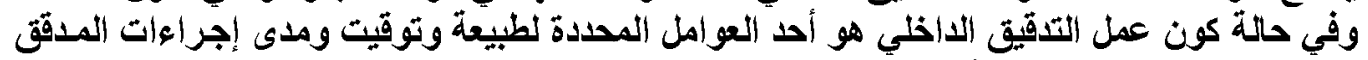

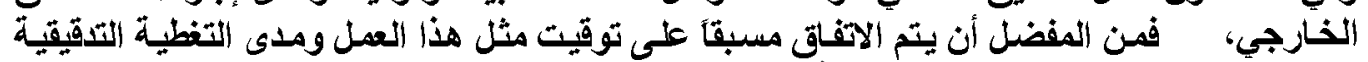

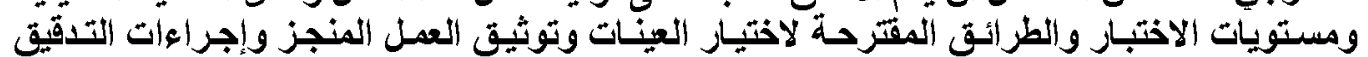
وإعداد التقارير.

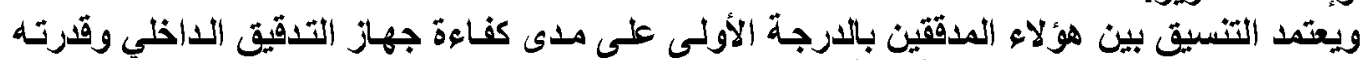

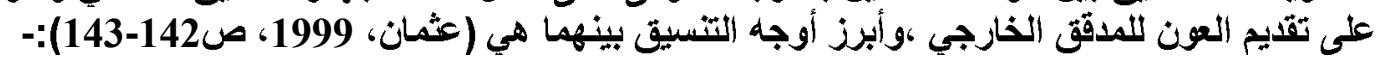

1- قيام المدقق اللاخلي بمسـاعدة المدقق الخارجي بإتجاز بعض الإجراءات المتعارف عليها كالقيام بإرسال التأييدات إلى المعنيلين.

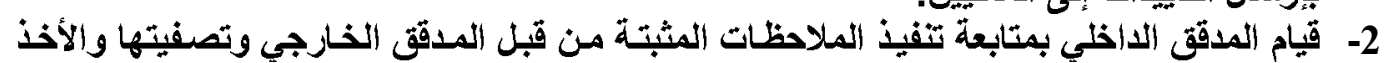
بها. 3- بالإمكان تشكيل لجان مشتركة بين الطرفين للقيام ببعض إجراءات التقيقئ.

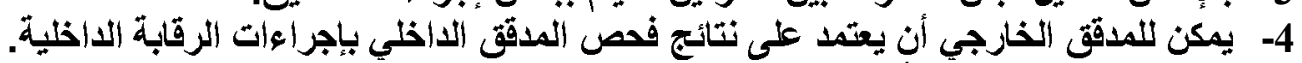

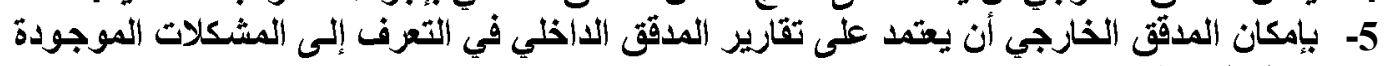

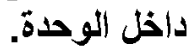
6- يمكن للمدقق الخارجي أن يختصر كثير من إجراءات التدقيق التي يتضمنها برنامجه عند فحصه

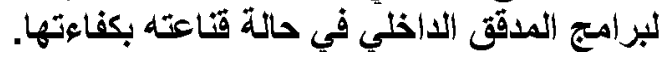




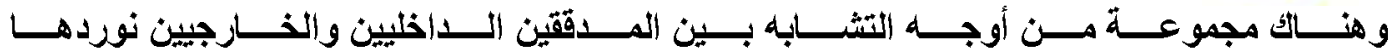

بالآتي(Arens\&Lobeck,2000,p.794)(Arens\&et.al.,2005,p.762):

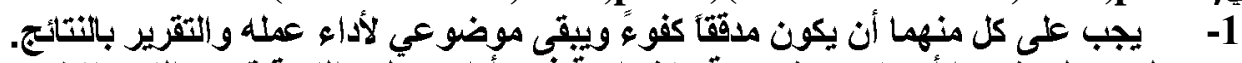

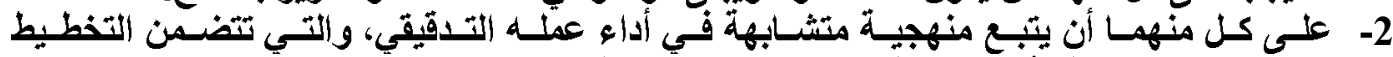

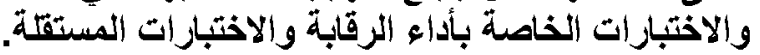

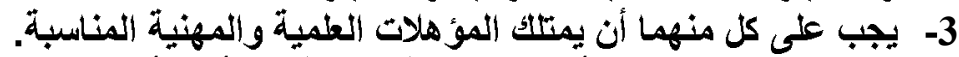

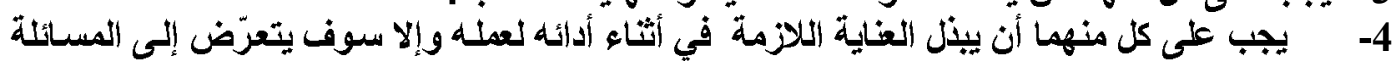

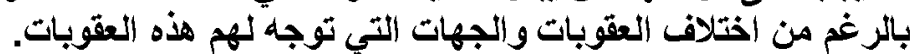

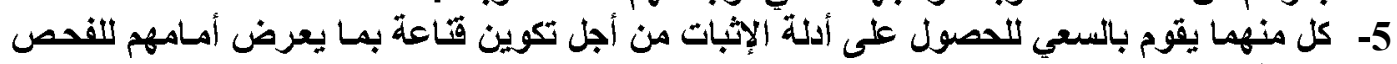

والتدقيق.

6- كل منهما يجب أن يلتزم بمعاييز التدقيق وقواعد السلوك وأخلاقيات العمل التدقيقي.

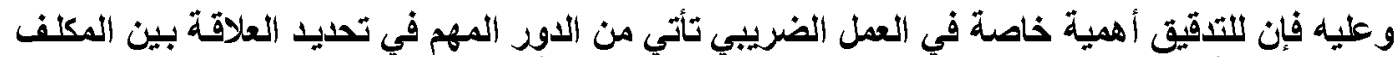

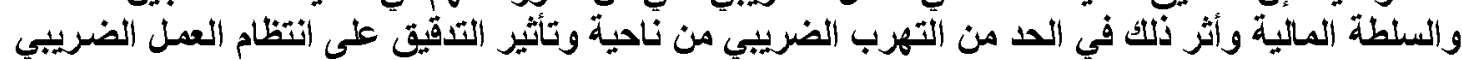

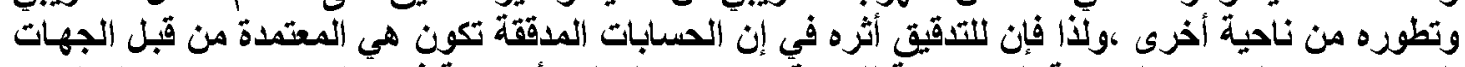

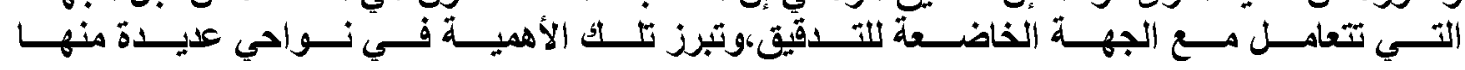

-:(www.ktaby.com,2007,p.28)

1- أهية التثقيق في التقليل من التهرب الضريبي ويكون ذلكت بجملة من الأمهور منها إلزام المكلفين

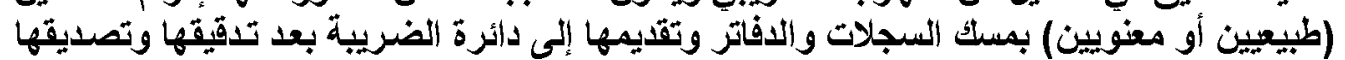

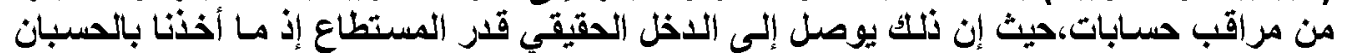

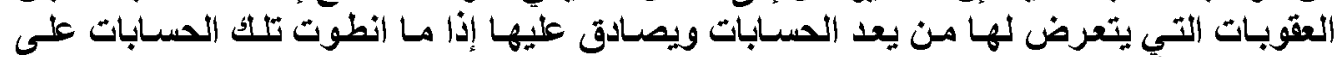

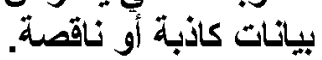

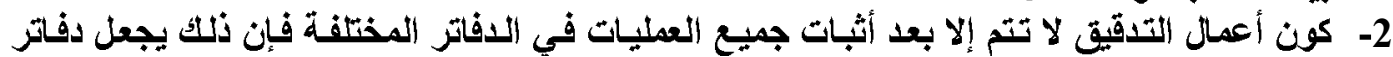

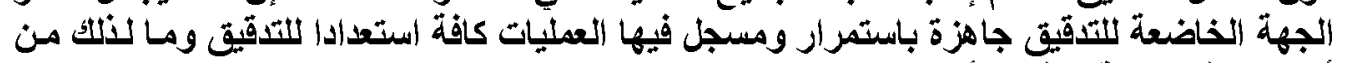

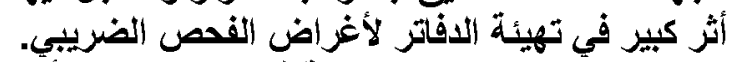

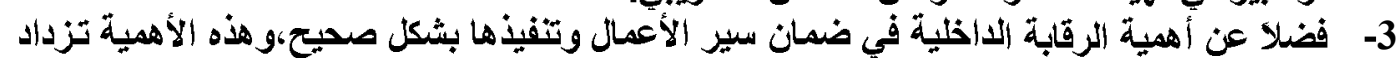

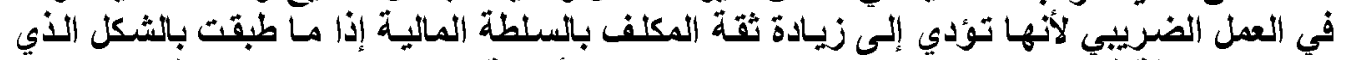

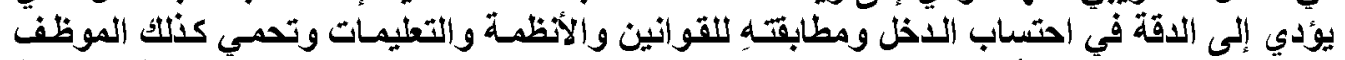

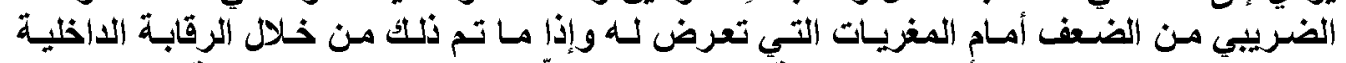

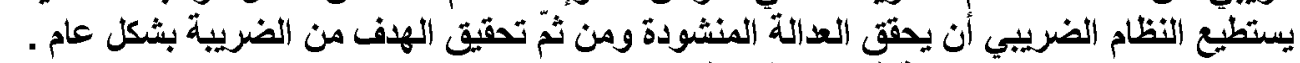

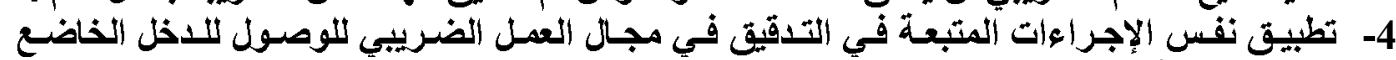

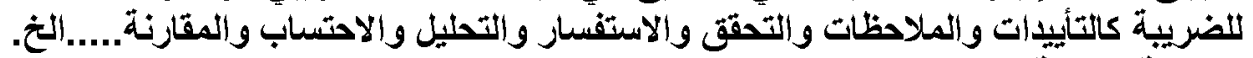

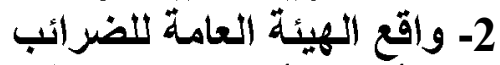

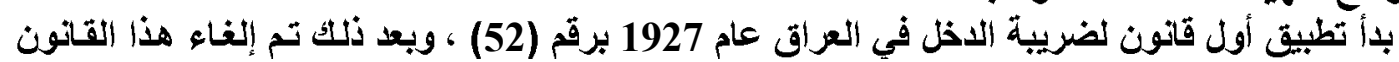

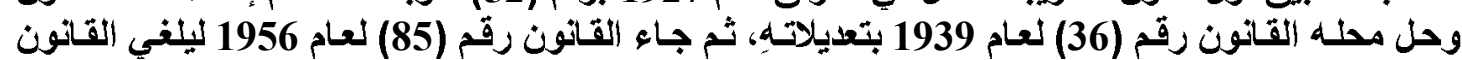

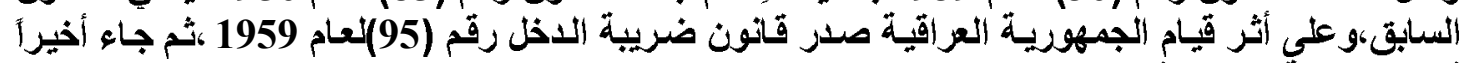

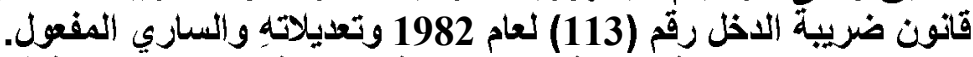

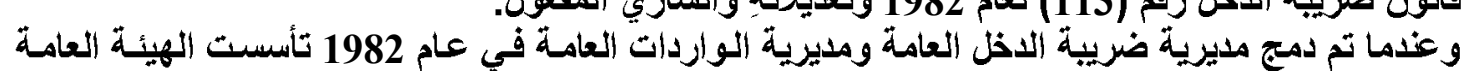
ويتكون الهيكل التنظيمي لهذه الهيئة من عدد من الأقهام والثُعب في مقر الهيئة يرتبط بها عدد من اللضر ائب. الفروع في بغداد والمحافظات. 


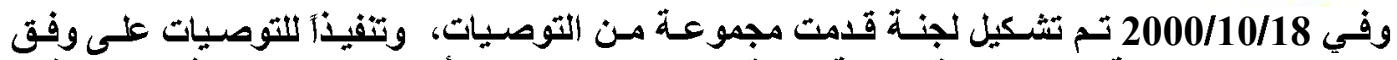

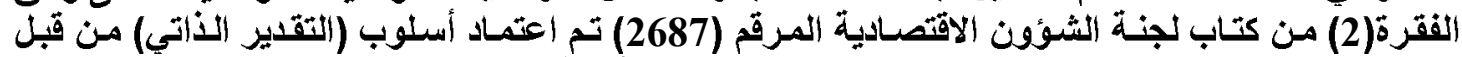

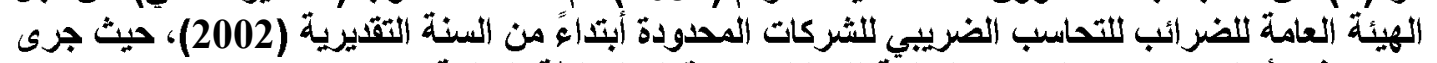

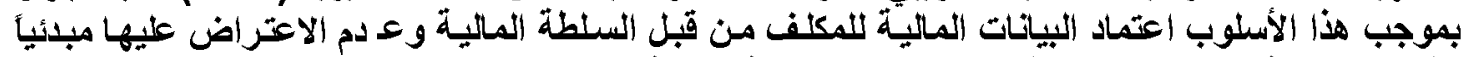

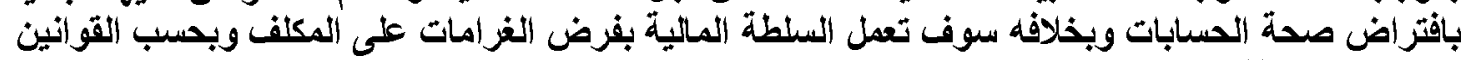

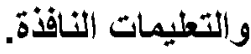

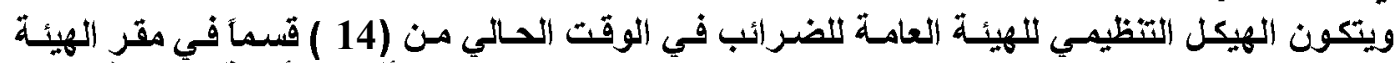

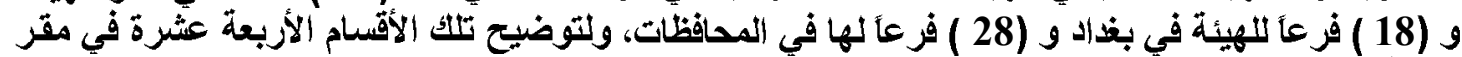

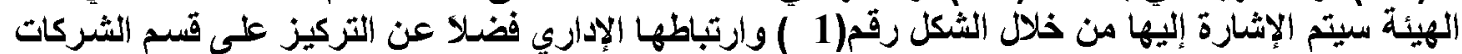

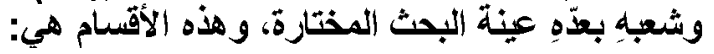

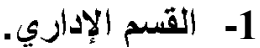

2- 20 - قسم التخطيط والمتابعة. 3- ق قسم الإحصاء والأبحاث.

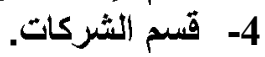

6- - - القسم القانوني.

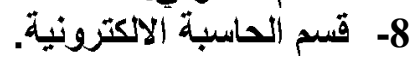

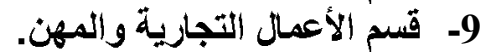
10- 10 قسم العقار والعرصات. 11- 11- قسم الاستقطاع المكار المباشر. 12- 12 قسم أرباح نقل الاستطلية. المباثي. 13- قسم المعلومات القنبة. 14- قسم العلاقات والأعلام. 13.

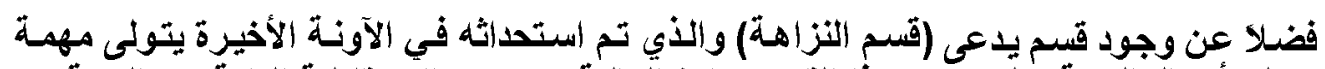

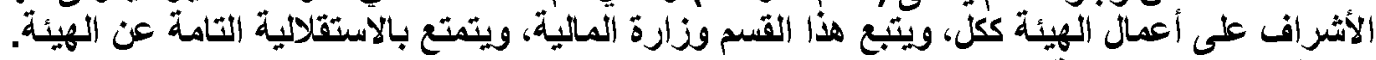
ويتكون قسم الثركات عينة البحث من : البرل 1- الوحدات التخمينية.

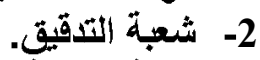
3- - 3 شعبة الجباية. 4- - وحدة الحاسبة الاكترونية. 5- 5 وحدة الصندوق. 


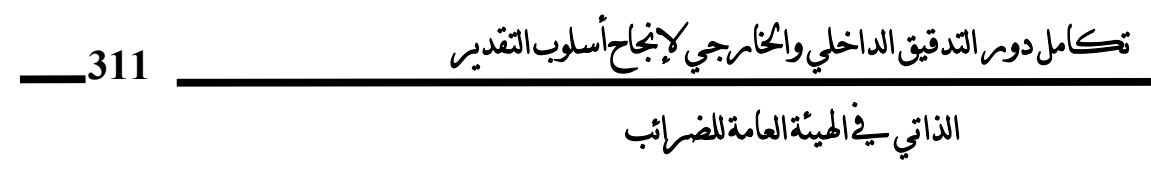

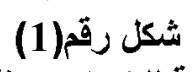

الهيكل التظظيمي لأقسام الهيئة العامة للضر رائب وشُعب قسم الثركات عينة البحث.

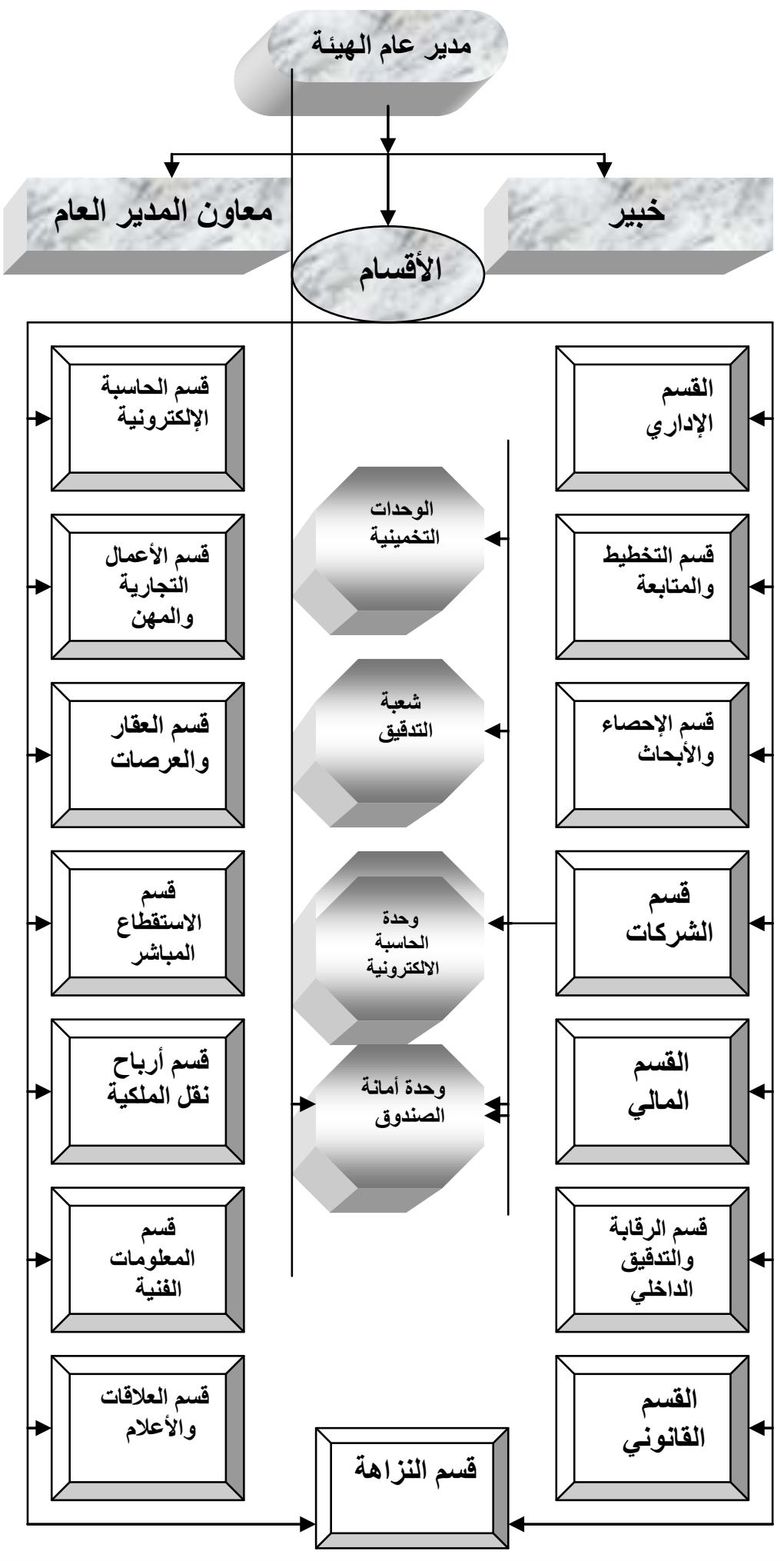




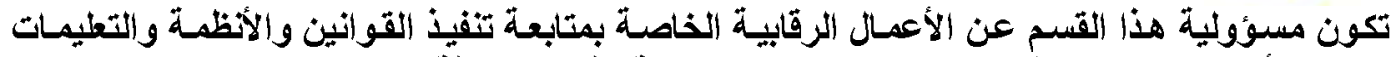

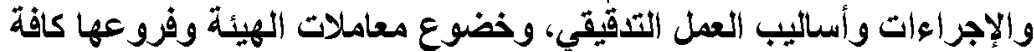

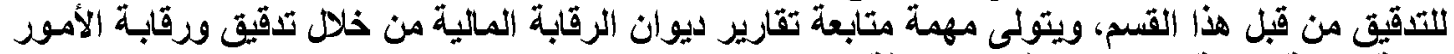

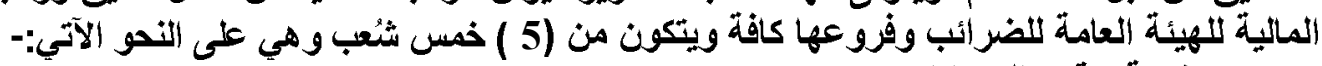

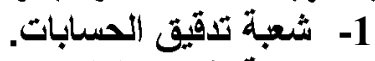

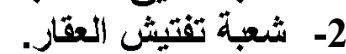

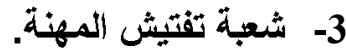

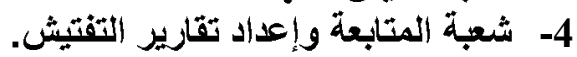
5- شبة التشقيق اللامركزي. والثكل رقم (2) يبين الهيكل التظظيمي ثهذا (لقسم.

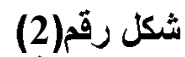

الهيكل التنظيمي لقسم الرقابة وآمالتذقيق الداخلي

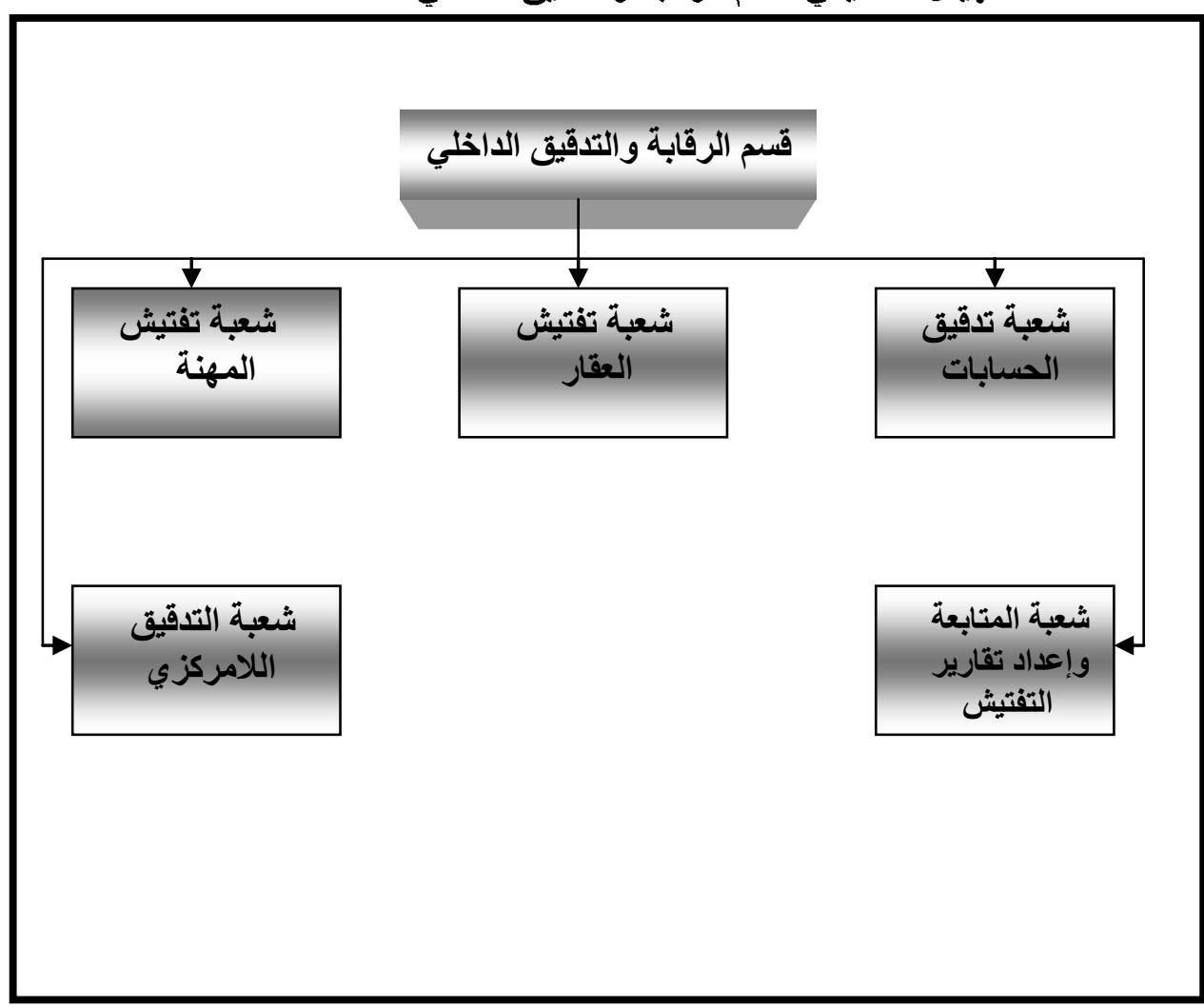

2- قسم الشركات في الهيئة العامة للضرائب

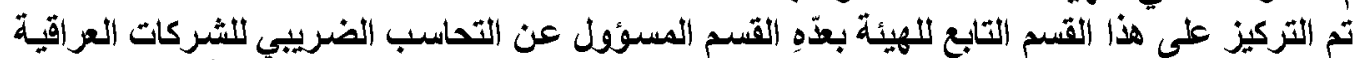

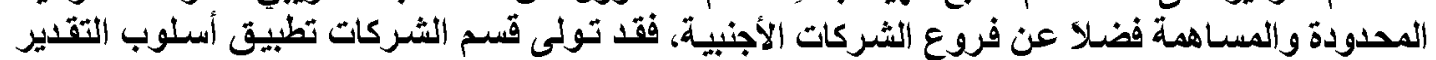

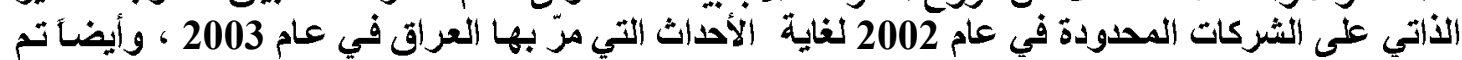

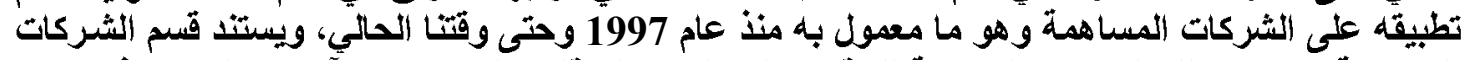

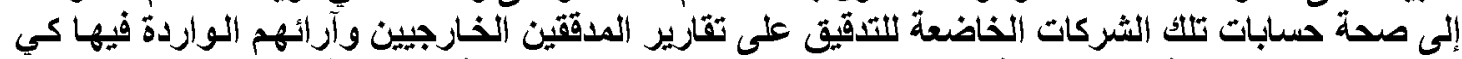

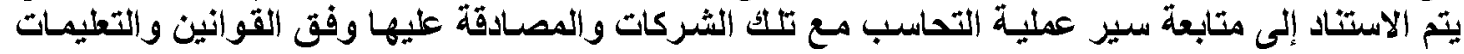

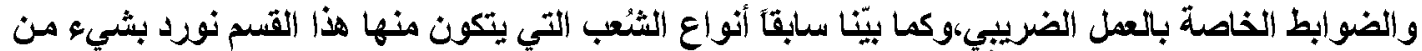
التفيل الثهام التي تتولى بالعل شعبة القيام بها وعلى النحو الآتي:- 
تتألف هذه الوحدات من (14) وحدة تخمينية، تضم كل وحدة موظف بلرجة (مخمن) وكاتب عدد (1)

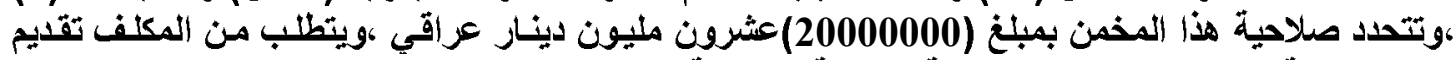

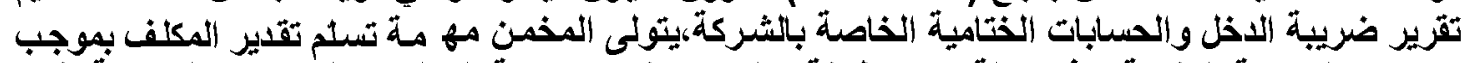

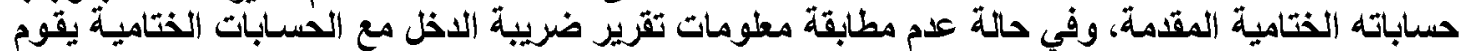
بناقشتها مع المكلف.

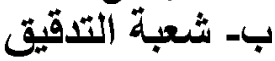

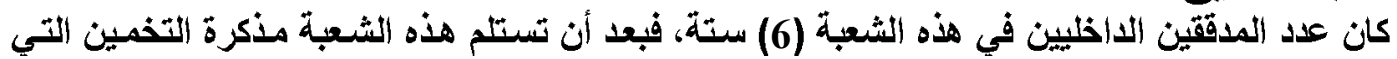

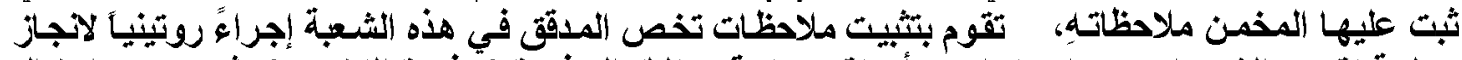

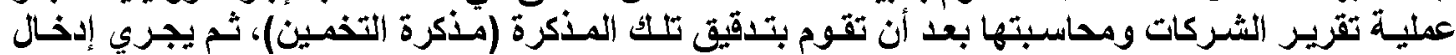

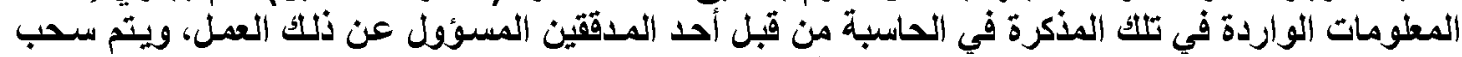

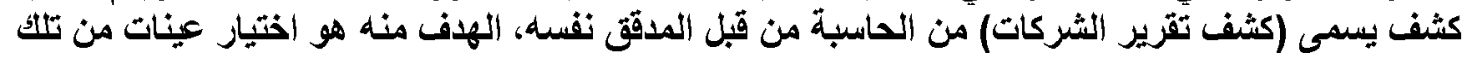

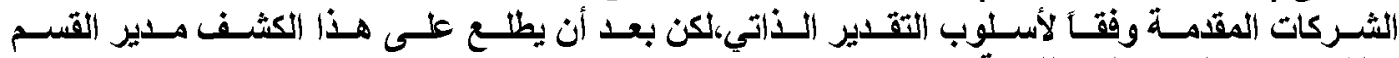
(قسم الثركات) و المدير العام للهيئة. ج- شعبة الجباية

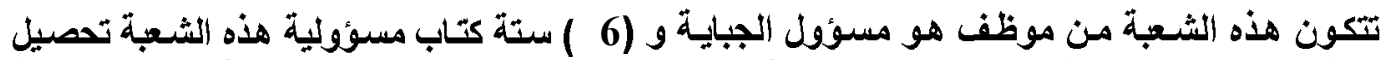

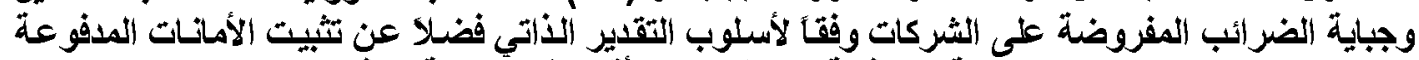

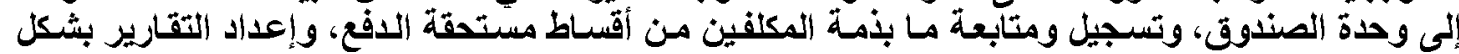

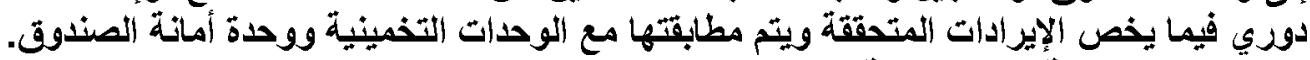

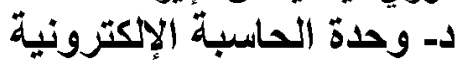

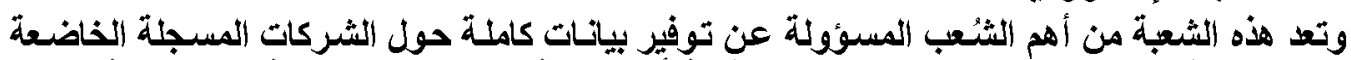

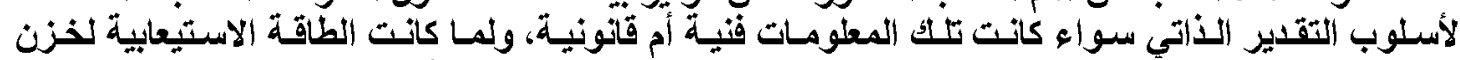

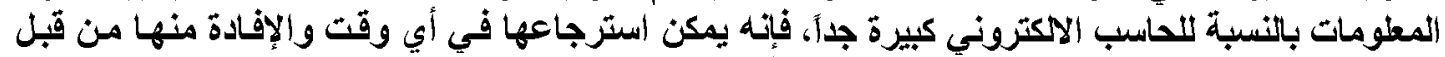

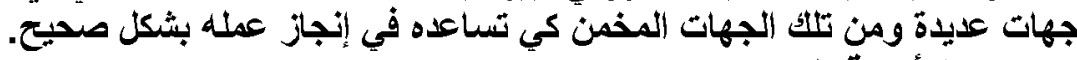

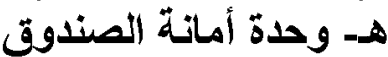

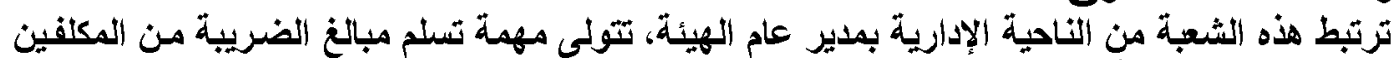

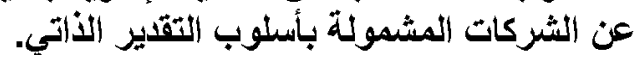

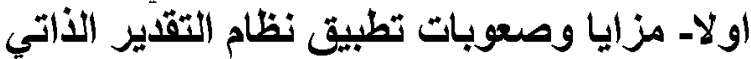

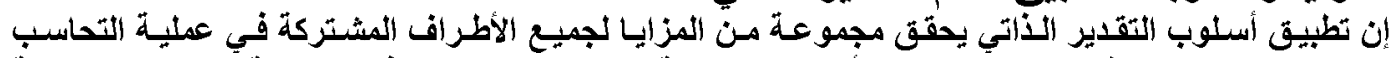

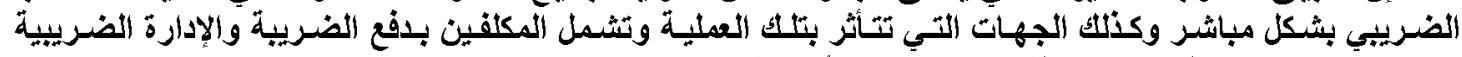

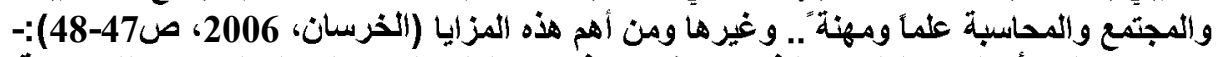

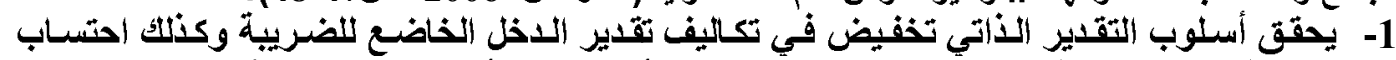

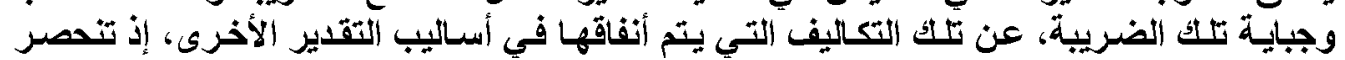

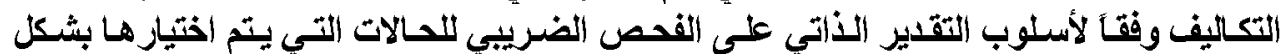
أستخائي. 2- إن أسلوبي التقلير الأتي يساعد في التخلص من الأساليب البدائية أو التقليدية للتقدير والتي تخطوي

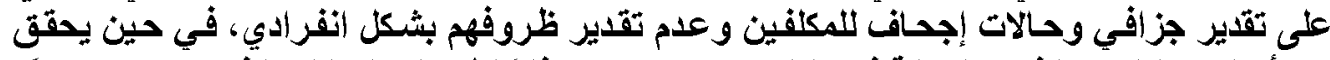

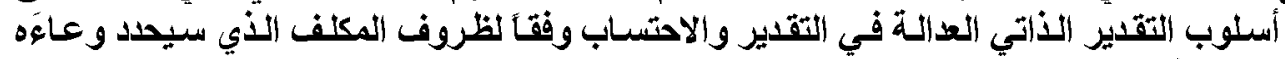
الضريبي بنفسية. 3- يدفع أسبوبي التقدير الذاتي باتجاه خلق ثقة متبادلة بين المكلف بدفع الضريبة والسلطة المالية،

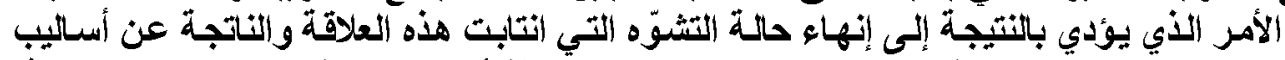

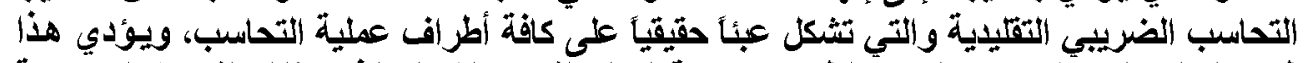

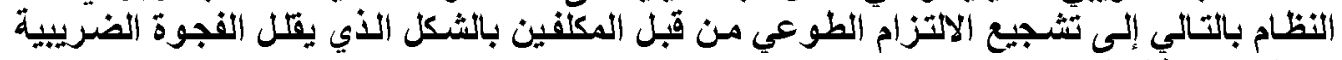
ويحقى الامتثال الضريبي. 


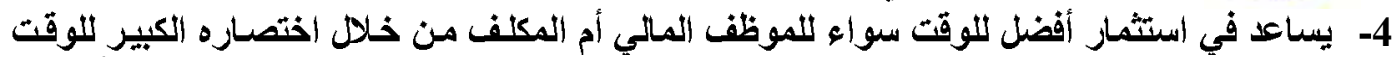

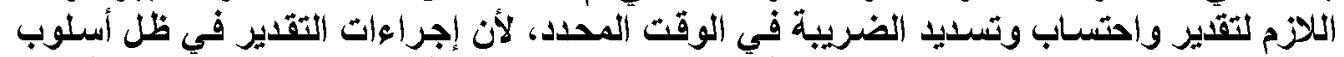

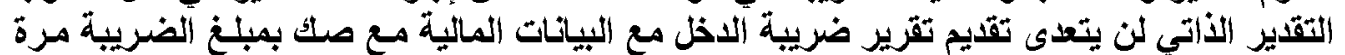

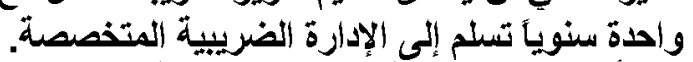

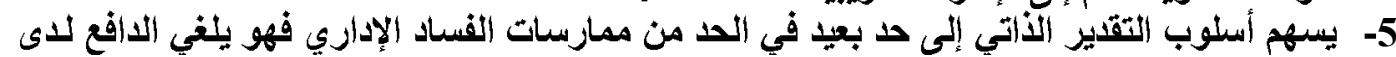

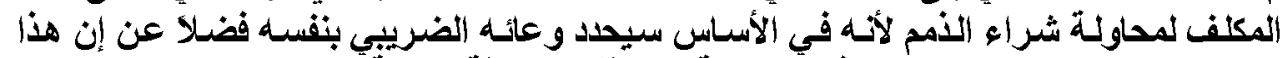

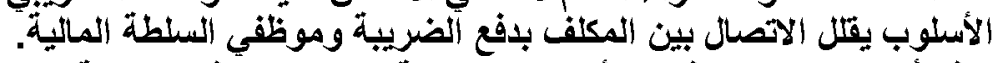

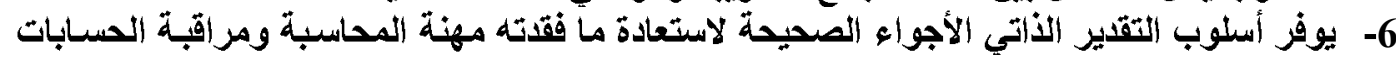

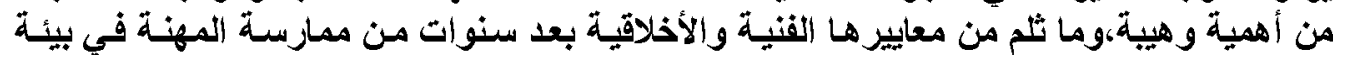

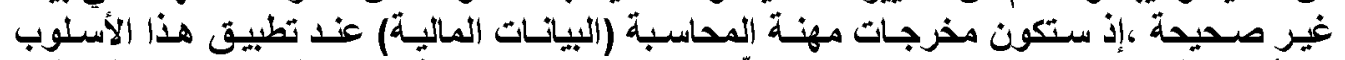

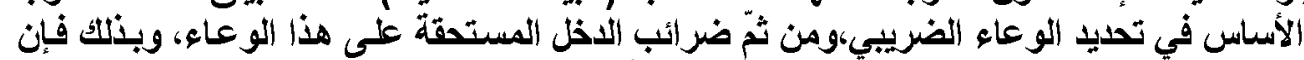

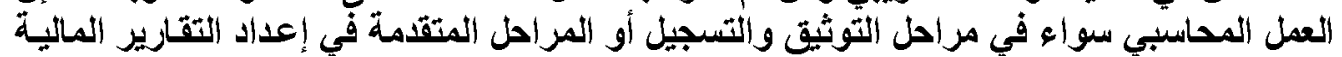

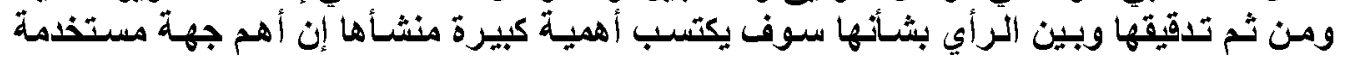

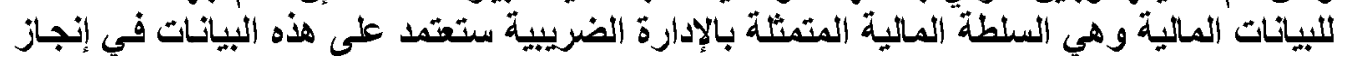

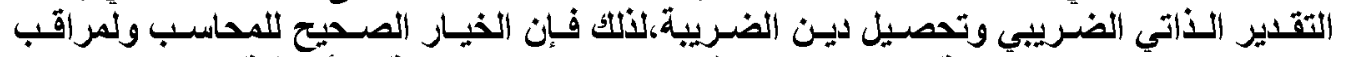

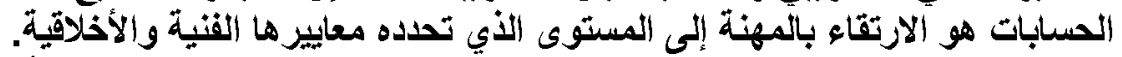

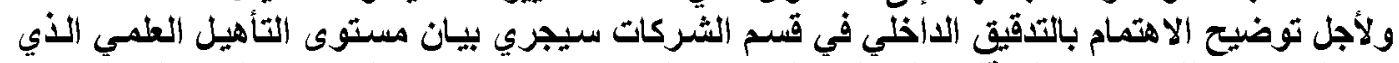

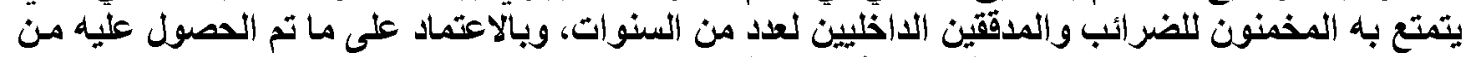

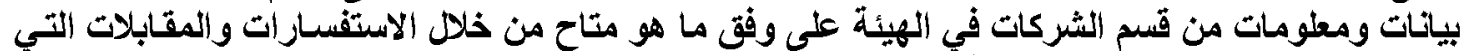

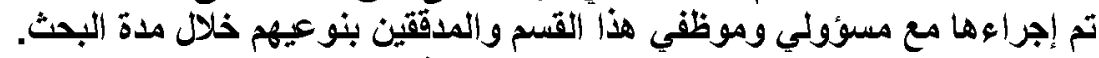

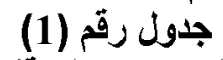

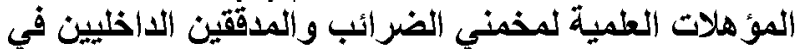
قسم الشركات بالهيئة لعام 2006

\begin{tabular}{|c|c|c|c|}
\hline المجموع & المدققون الداخليون & مخمنو الضرائب & المؤهل العلمي \\
\hline 1 & --- & 1 & - دبلوم قَي \\
\hline 7 & 2 & 5 & - بكالوريوس \\
\hline 10 & 3 & 7 & - ماجستير \\
\hline 18 & 5 & 13 & المجموع \\
\hline
\end{tabular}

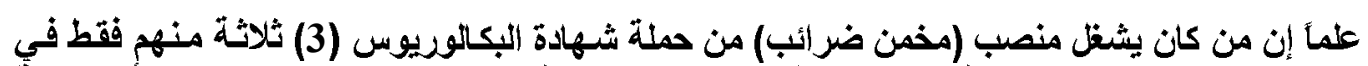

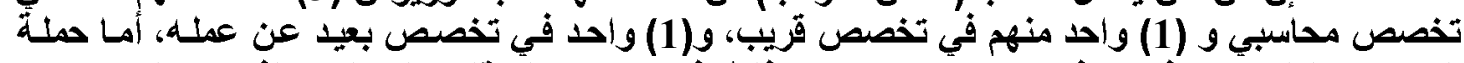

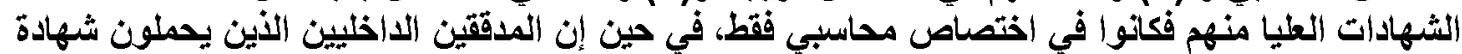

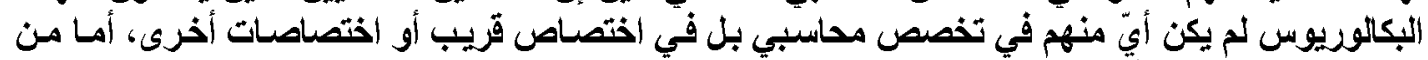

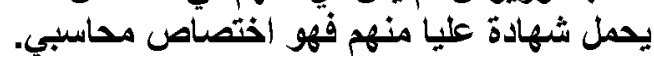
أما سنوات الخبرة لمخمني الضر ائب والمدققين الأخليين خلال العام نفسه فالجدول رقم (2) يبين ذلك. 
جدول رقم (2) جمثن

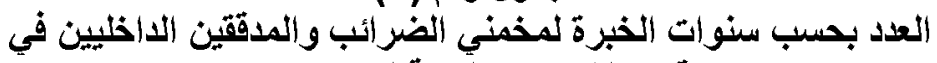

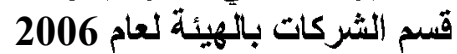

\begin{tabular}{|c|c|c|c|c|}
\hline 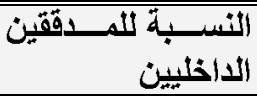 & الضرأبة لمخمنحة & ألإخدلينين (التكرار) للمدققين & المخمنـي الضر (التكـــــار) & المدة \\
\hline$\% 100$ & $\% 69$ & 5 & 9 & ــ أقلّ من 5 سنوات \\
\hline$\overline{---}$ & $\% 31$ & --- & 4 & ـ أكثر من 10 سنوات \\
\hline$\% 100$ & $\% 100$ & 5 & 13 & المجموع \\
\hline
\end{tabular}

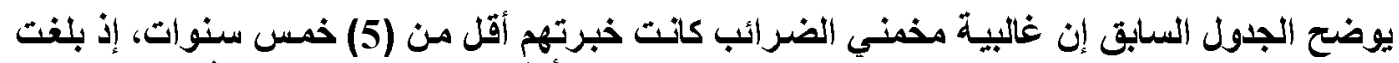

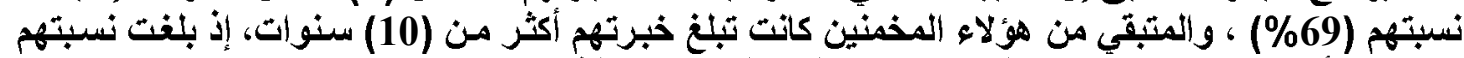

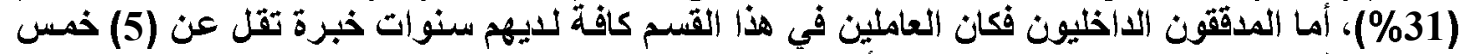

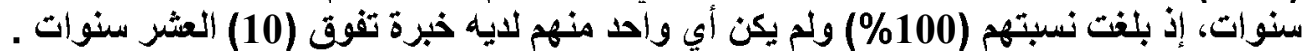

\section{جدول رقم(3)}

المؤ هلات العلمية لمخمنى الضر ائب في قشم رقمركات الثركات بالهيئة لعام 2007

\begin{tabular}{|c|c|c|}
\hline النسبة & مخمنو الضرائب & المؤهل العلمي \\
\hline$\% 6$ & 1 & ـ ـ دبلوم قني \\
\hline$\% 47$ & 7 & - بكالوريوس \\
\hline$\% 47$ & 7 & ماجستير \\
\hline \%100 & 15 & ــ المجموع \\
\hline
\end{tabular}

هن أعلاه نلحظ إن غالبية المخمنين لهنا العام هم من حملة الثـهادات العليا في المحاسبة على وجها

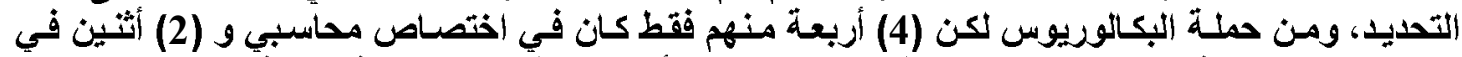

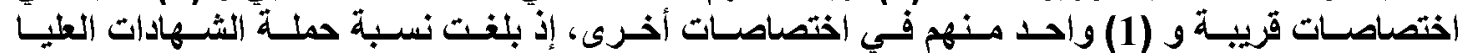

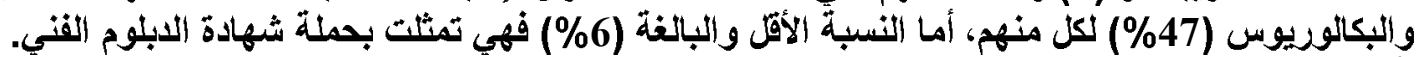

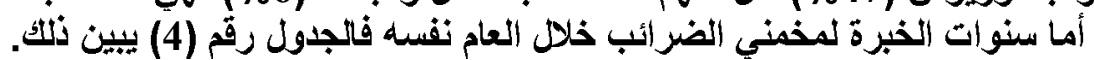

$$
\begin{aligned}
& \text { جدول رقم) } \\
& \text { العدد حسب سنوات الخبرة لمخني الضرائب في قسم الثركات بالهيئة } \\
& \text { لعام } 2007
\end{aligned}
$$

\begin{tabular}{|c|c|c|}
\hline النسبة لمخمني الضر ائب & التعدد (التكرا) لمخمني الضر ائب & المدة \\
\hline$\% 80$ & 12 & من 10 سنوات فأكثر \\
\hline$\% 7$ & 1 & من 15 سنة فأكثر \\
\hline$\% 13$ & 2 & من 20 سنة فَأكثر \\
\hline $\begin{array}{l}--- \\
--\end{array}$ & 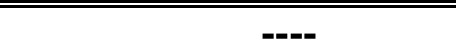 & 25 سنة فَأكثر \\
\hline$\% 100$ & $\overline{15}$ & المجموع \\
\hline
\end{tabular}




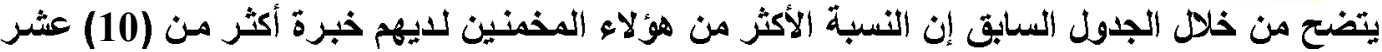

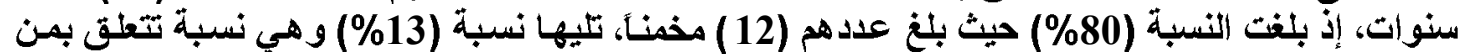

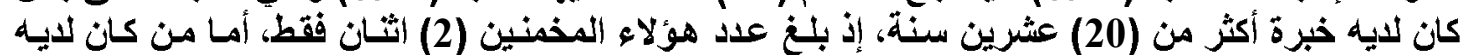

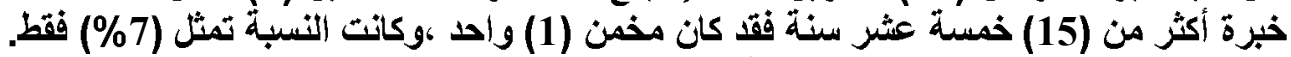

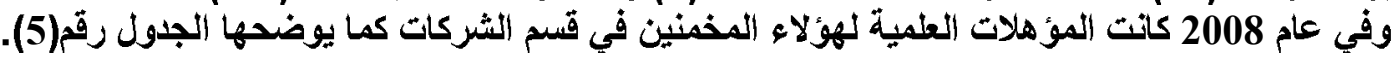

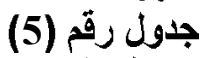
المؤ هلات العلمية لمخمني الضر ائب في قسم الثركات بالهيئة لعام 2008

\begin{tabular}{|c|c|c|}
\hline النسبة لمخمني الضرائب & مخمنو الضرانب & المؤهل العلمي \\
\hline$\% 14$ & 4 & - بكالوريوس \\
\hline$\% 32$ & 9 & ـ دبلوم عالي مراقبة الحسابات \\
\hline$\% 25$ & 7 & - ماجستير \\
\hline$\% 29$ & 8 & - دكتوراه \\
\hline$\% 100$ & 28 & المجموع \\
\hline
\end{tabular}

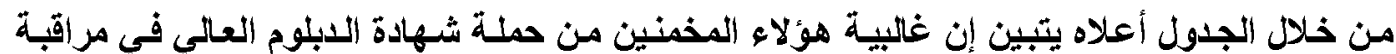

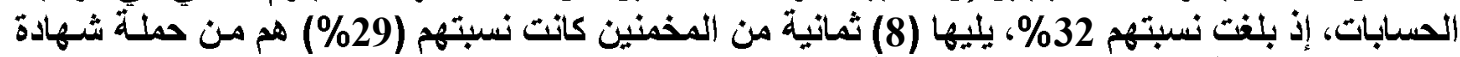

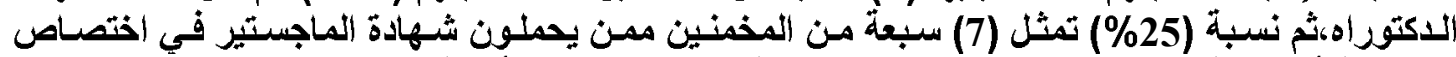

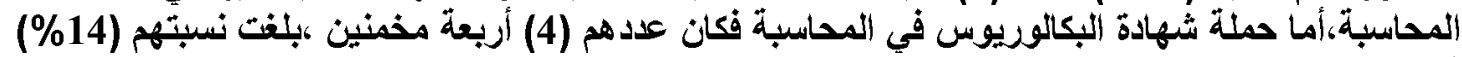
قفط. في حين إن سنوات الخبرة لهؤلاء المخمنين سيتم توضيحها بالجدول رقم (6) ـ

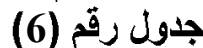
العدد بحسب سنوات الخبرة لمخمني الضر ائب في قسم الثركات بالأهيئة لعام 2008

\begin{tabular}{|c|c|c|}
\hline النسبة لمخمني الضر ائب & العدد (التكرار) مخمني الضر ائب & الالمدة \\
\hline$\% 21$ & 6 & - من 1- 10 سنوات \\
\hline$\% 61$ & 17 & - من 11- 20 سنة \\
\hline$\% 14$ & 4 & - من 21- 30 سنة \\
\hline$\% 4$ & 1 & - 30 سنة فأكثر \\
\hline$\% 100$ & 28 & المجموع \\
\hline
\end{tabular}

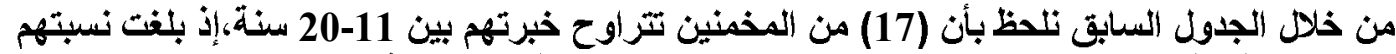

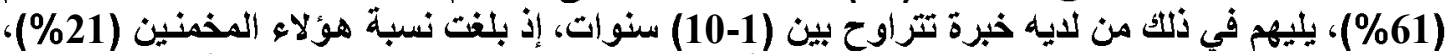

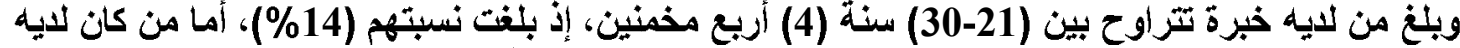

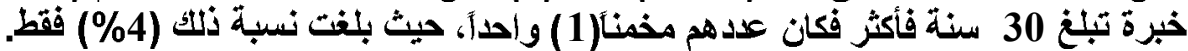

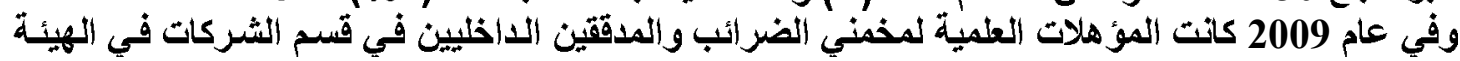
كما يوضحها (الجدول رقم (7) 
المؤهلات العلمية لمخمني الضرائب والمدققين الداخليين في الهيئة لعام 2009

\begin{tabular}{|c|c|c|c|c|}
\hline النسبة المئوية & الالاخليون & النسبة المئوية & مخمنو الضرائب & المؤهل العلىي \\
\hline \%16 & $\overline{1}$ & $\% 8$ & 1 & - دبلوم فني \\
\hline$\% 50$ & 3 & $\% 38$ & $\overline{5}$ & - بكالوريوس \\
\hline$\% 17$ & $\overline{11}$ & \%38 & $\overline{5}$ & ـ دبلوم عالمي في الضرائب \\
\hline$\% 17$ & $\overline{1}$ & $\overline{\% 8}$ & 1 & ـ شهادة المحاسبة القانونية \\
\hline 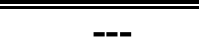 & $\begin{array}{c}--- \\
-\end{array}$ & $\% 8$ & 1 & - ماجستيز \\
\hline \%100 & $\overline{6}$ & $\% 100$ & 13 & ـ المجموع \\
\hline
\end{tabular}

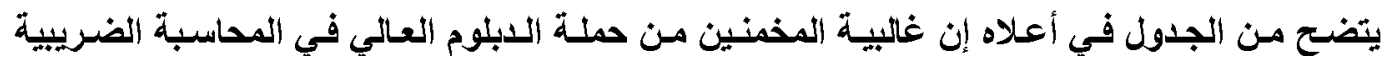

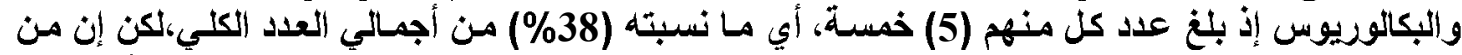

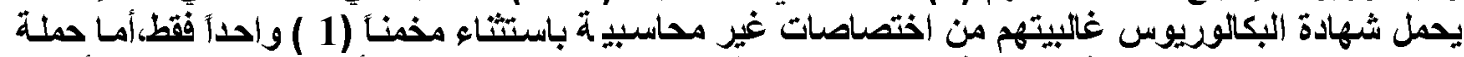

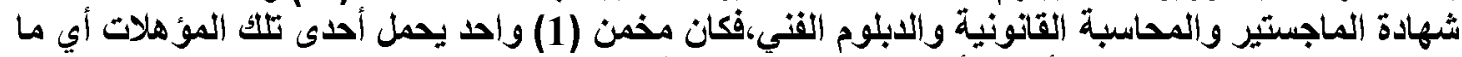

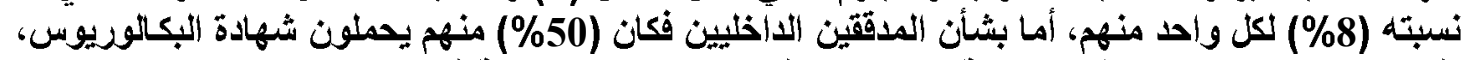

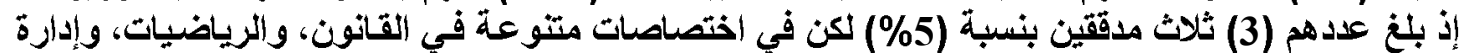

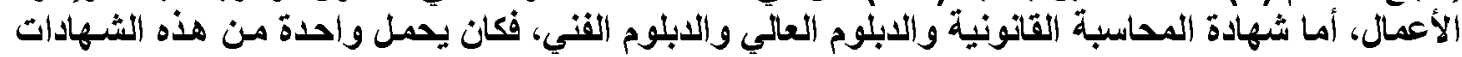

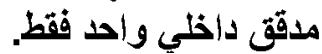

أما سنوات الخبرة لهوُلاء المخمنين والمدققين فيمن توضيحها بالجبول رقم(8)

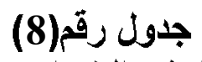

العدد بحسب سنوات الخبرة لمخمني الضرأب وأب والمدققين الداخليين في قسم

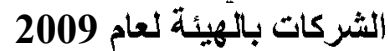

\begin{tabular}{|c|c|c|c|c|}
\hline 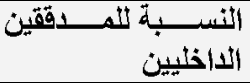 & الضـرائب بـة لمخمنـــــي & 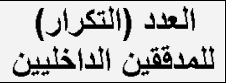 & الضــدائب (التكرار) 'مخنــو & المدة \\
\hline$\% 83$ & $\% 100$ & 5 & 13 & ـ من 1- 10 سنوات \\
\hline$\% 17$ & --- & 1 & --- & ـ من 11- 20 سنة \\
\hline$\% 100$ & $\% 100$ & $\overline{6}$ & 13 & المجموع \\
\hline
\end{tabular}

ولأجل إجراء نوع من المقارنة بين مؤهلات وسنوات خبرة المخمنين والمدققين بين عام وام 2006 بعدّها

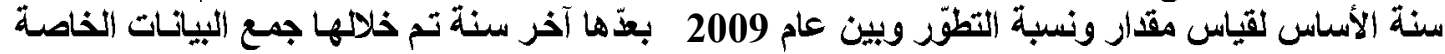

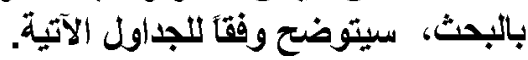


جدول رقم (9)

مقار التطوز بين عام 2006 و2009 في فول المؤهلات العلمية لمخمني

الضر ائب والمدقين الداخليين في قُم الثركات بالهيئة.

\begin{tabular}{|c|c|c|c|c|c|c|}
\hline 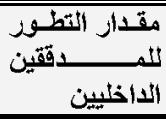 & لمختدنين التطـور & ألمام 2009 ألمـاخليون & عام 2009 & 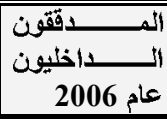 & ألمخمن 2006 كـن & المؤهل العلمي \\
\hline 1 & -- & 1 & 1 & --- & 1 & ـ دبلوم قني \\
\hline 1 & --- & 3 & 5 & 2 & 5 & - بكالوريوس \\
\hline$\overline{1}$ & $\overline{5}$ & $\overline{1}$ & $\overline{5}$ & 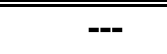 & $\overline{~---}$ & ـ دبلوم عـلـي في \\
\hline 1 & 1 & 1 & 1 & $\begin{array}{l}-- \\
\end{array}$ & $\begin{array}{l}-- \\
\end{array}$ & قـ شـهادة محاسبة \\
\hline (3) & $\overline{(6)}$ & --- & 1 & 3 & 7 & - ماجستير \\
\hline 1 & $\overline{\mathbf{0}}$ & $\overline{6}$ & 13 & 5 & 13 & ألمجموع \\
\hline
\end{tabular}

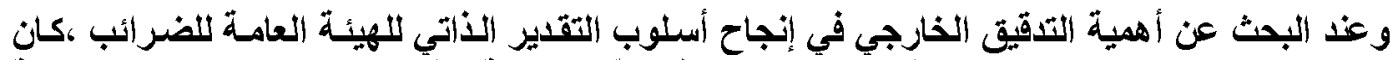

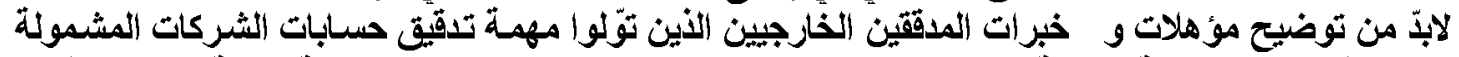

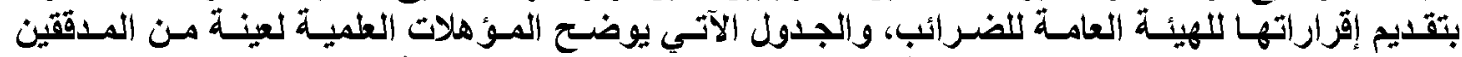

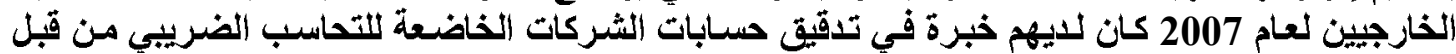

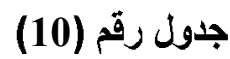

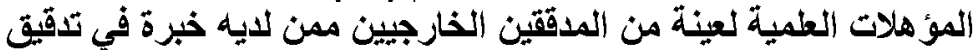
الثركات الخاضعة للتحاسب الضرن الضيبي من قبل الهيئة لعام 2007

\begin{tabular}{|c|c|c|}
\hline النسبة & المدققون الخارجيون & ألمؤهل الطمي \\
\hline$\% 50$ & 15 & - بكالوريوس \\
\hline$\% 10$ & 3 & - دبلوم عالي مراقبة الحسابات \\
\hline$\% 7$ & 2 & - ماجستير \\
\hline$\% 33$ & 10 & - دكتوراه \\
\hline$\% 100$ & 30 & المجموع \\
\hline
\end{tabular}

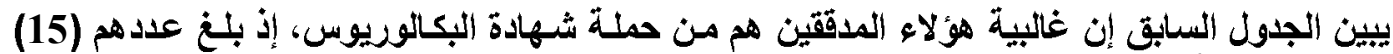

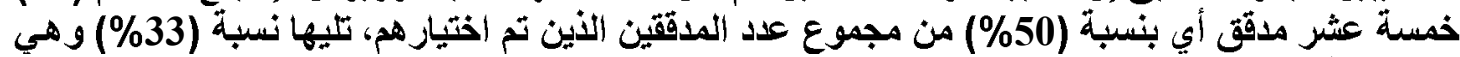

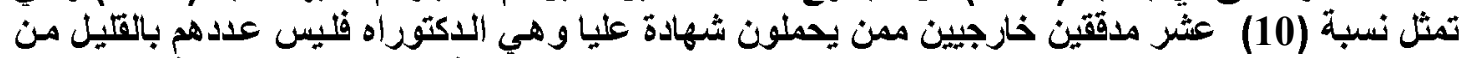

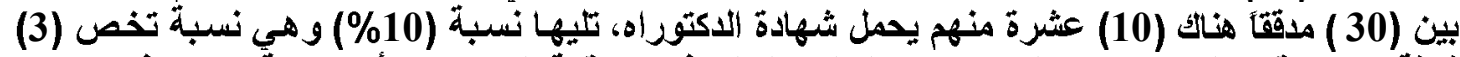

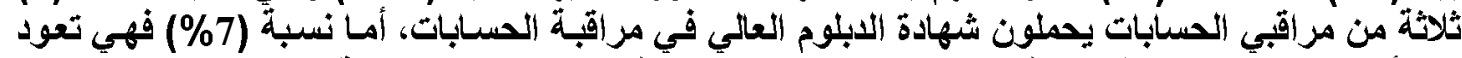

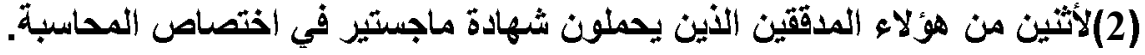




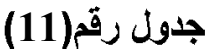

سنوات الخبرة لعيذة من المدققين الخازبين ممن لايه خبرة في تدقيق الثركات

الخاضعة للتحاسب الضريبي من قبل الهيئة لعام 2007

\begin{tabular}{|c|c|c|}
\hline النسبة & العدد (التكرار) للمدقتين الخارجيين & المدة \\
\hline$\% 36$ & 11 & - 10- 15 سنة \\
\hline$\% 17$ & 5 & - 16- 20 سنة \\
\hline$\% 17$ & $\overline{5}$ & - 21- 25 سنة \\
\hline \%30 & 9 & - 25 سنة فُأكثر \\
\hline$\% 100$ & 30 & المجموع \\
\hline
\end{tabular}

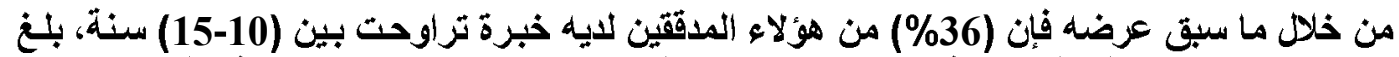

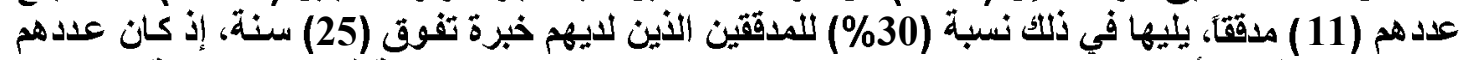

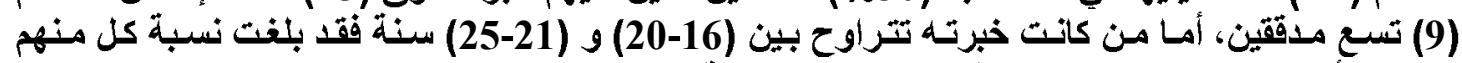

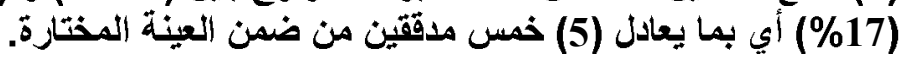

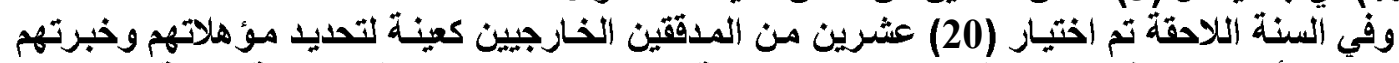

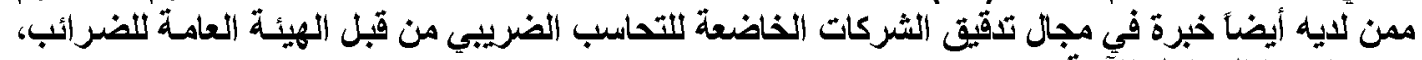
والتي توضحها الجداول الآتية.

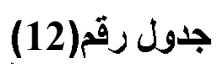

المؤهلات العلمية لعينة من مراقبي الحسابات ممن لديه خبرة في تدقيق الشركات الخاضعة للتحاسب الضريبي من قبل الهيئة العامة للضر ائب لعام 2008

\begin{tabular}{|c|c|c|}
\hline النسبة & المدققون الخارجيون & اللمؤهل العلمي \\
\hline$\% 10$ & 2 & - بكالوريوس \\
\hline$\% 50$ & 10 & - دبلوم عالّي مراقبة الحسابات \\
\hline$\% 25$ & 5 & - ماجستير \\
\hline$\% 15$ & 3 & - دكتوراه \\
\hline$\% 100$ & 20 & المجموع \\
\hline
\end{tabular}

في هذه العينة كان (50\%) منهم يحملون شهادة الابلوم العال في مراقبة الحسـابات وهي شهادة عليا

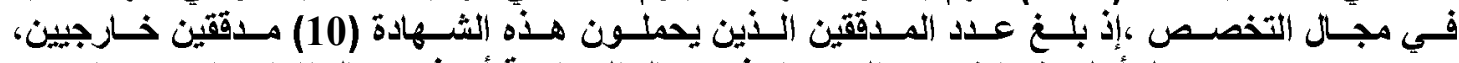

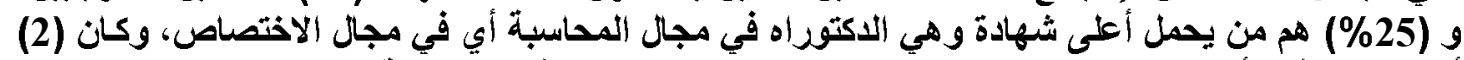

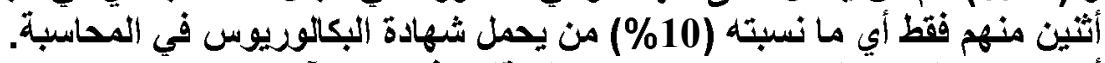
أما سنوات الخبرة التي يتمتع بها هؤلاء المدقئين فكانت كالآتي: 


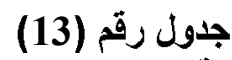

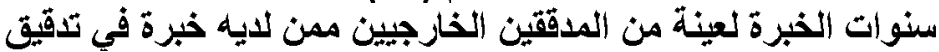

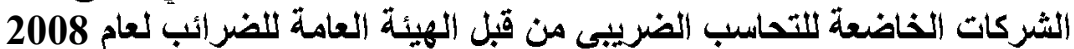

\begin{tabular}{|c|c|c|}
\hline النسبة & العدد(التكرار) للمدققين الخارجيين & المدة \\
\hline$\% 15$ & 3 & - 1- 10 سنوات \\
\hline$\%$ \%55 & 11 & - 11- 20 سنة \\
\hline$\% 25$ & 5 & - 21- 30 سنة \\
\hline$\% 5$ & 1 & - 30 سنة فَأكثر \\
\hline$\% 100$ & 20 & المجموع \\
\hline
\end{tabular}

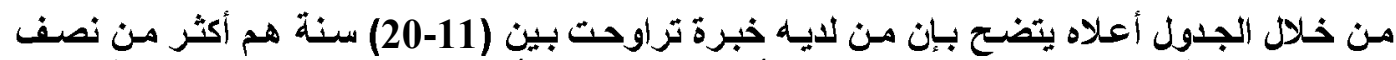

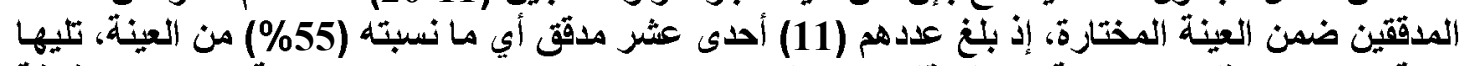

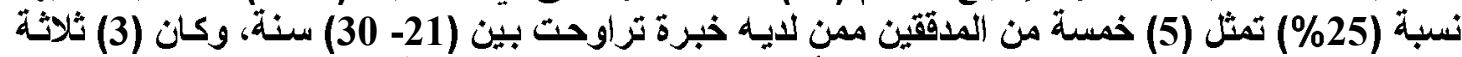

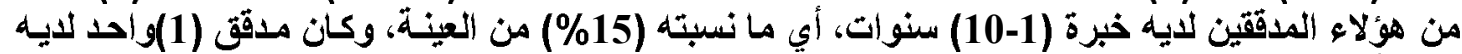

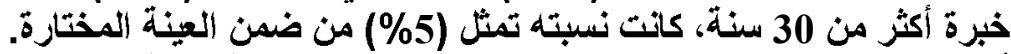
أمسا في عام 2009 فيوضح الجدول الآتي المؤهلات العلمية لعينة من المدققين الخـارجيين بلنغ عددهم (40)

جدول رقم (14)

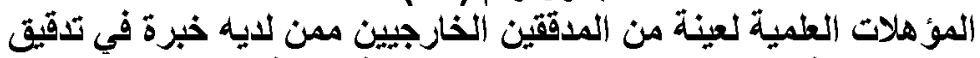

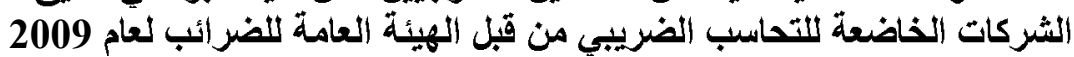

\begin{tabular}{|c|c|c|}
\hline النسبة & المدققين الخار جيين & المؤهل العلمي \\
\hline$\% 12$ & 5 & ــ دبلوم عالئ مراقبة الحسابات \\
\hline$\% 65$ & 26 & - ماجستير \\
\hline$\% 23$ & 9 & - دكتوراه \\
\hline$\% 100$ & 40 & المجموع \\
\hline
\end{tabular}

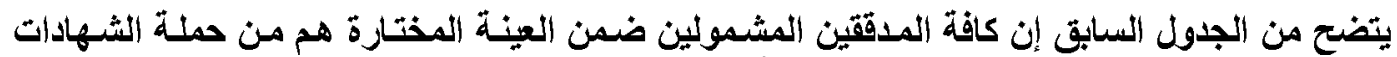

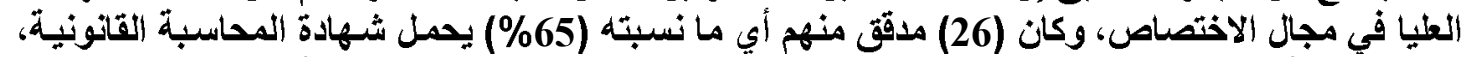

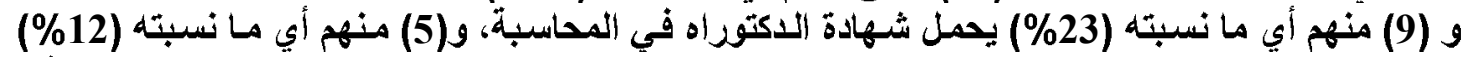

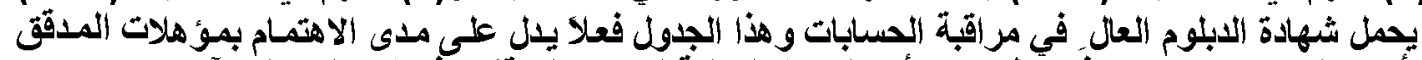

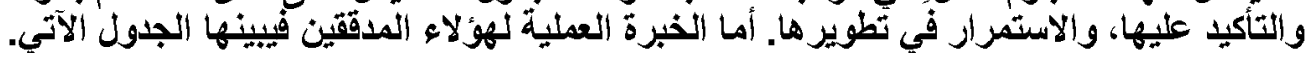


جنول رقام (15)

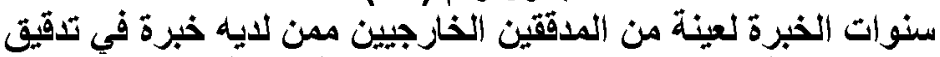

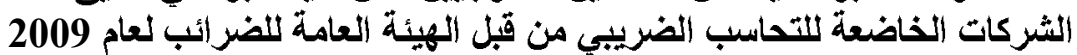

\begin{tabular}{|c|c|c|}
\hline |لالنسبة & العدد (التكرار) للمدققين الخارجيين & المدة \\
\hline$\% 22$ & 9 & - 1- 5 سنوات \\
\hline$\% 28$ & 11 & - 6- 10 سنوات \\
\hline \%30 & 12 & - 11- 15 سنة \\
\hline$\% 20$ & 8 & ـ أكثر من 15 سنة \\
\hline \%100 & 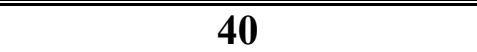 & المجموع \\
\hline
\end{tabular}

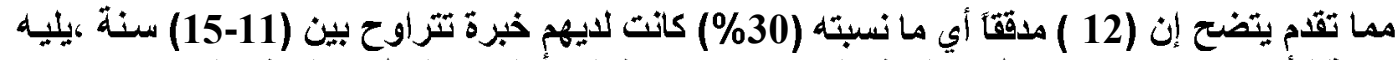

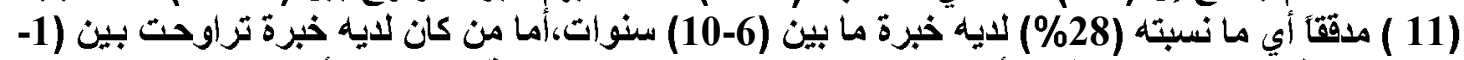

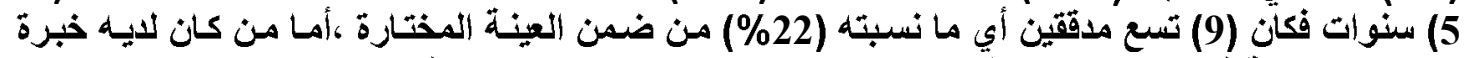

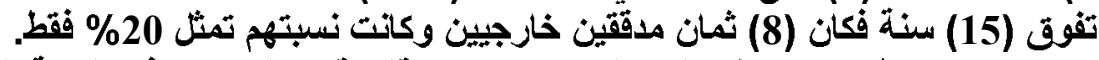

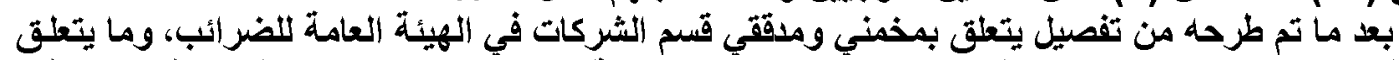

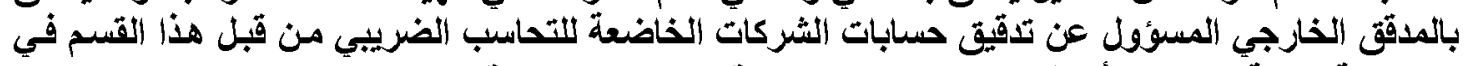

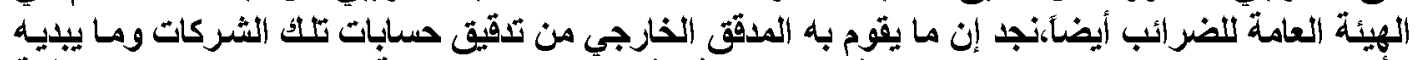

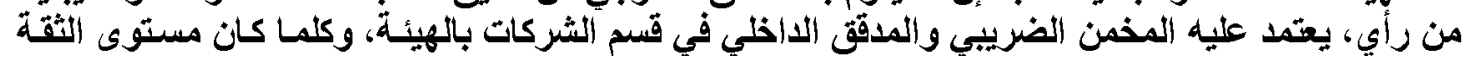

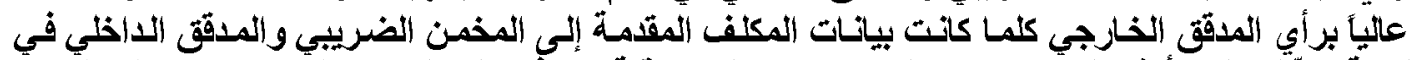

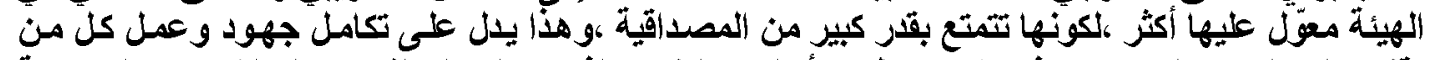

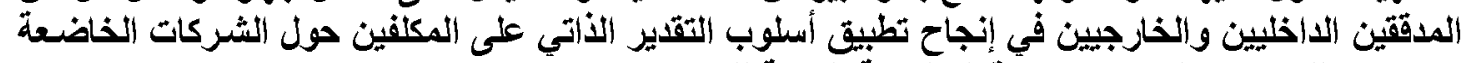

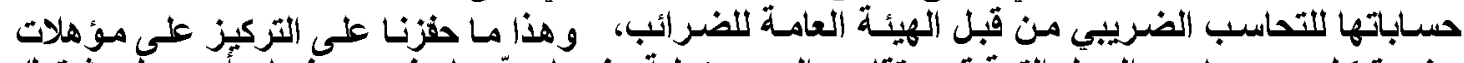

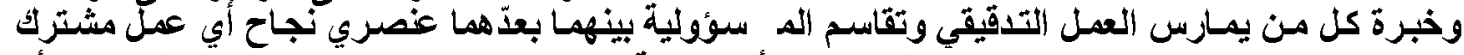

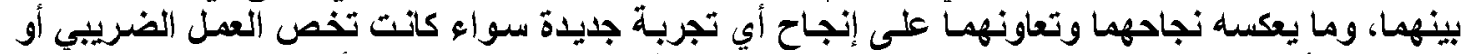

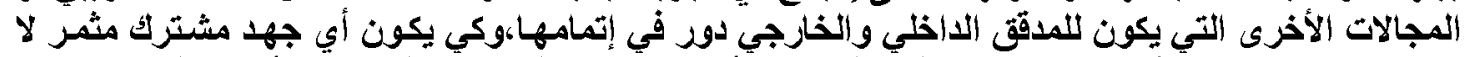

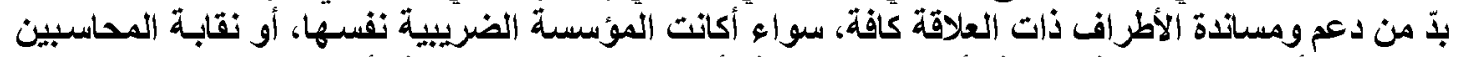

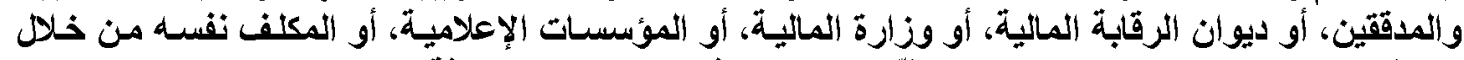

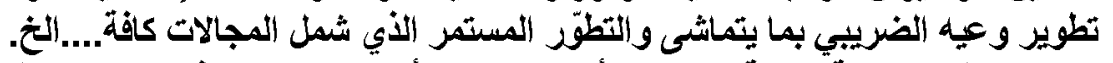

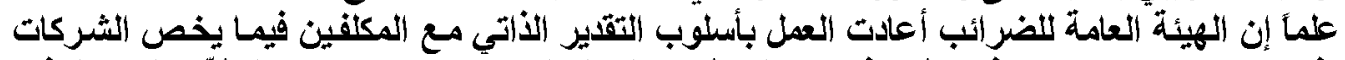

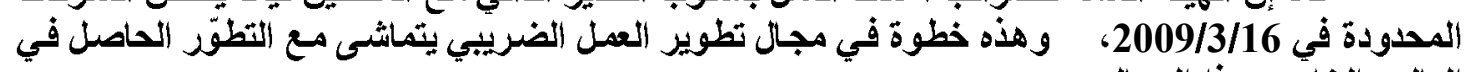
العالم والخاص بهئا المجال. 


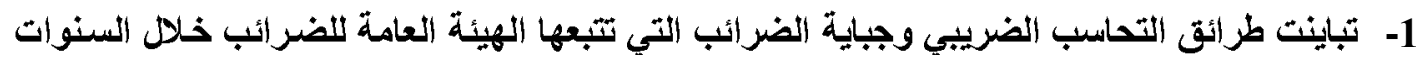

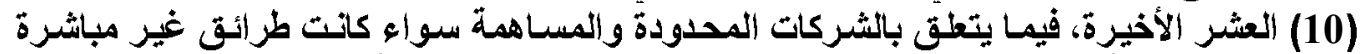

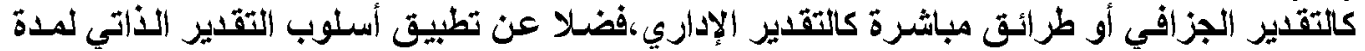

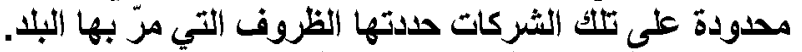

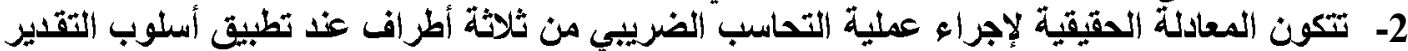

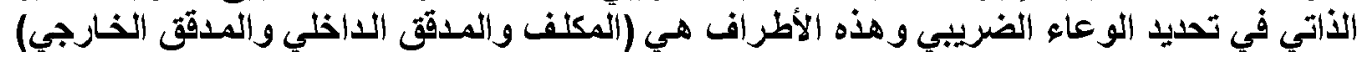

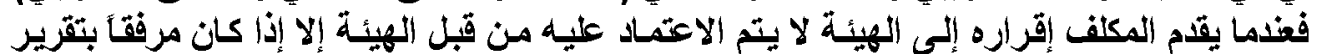

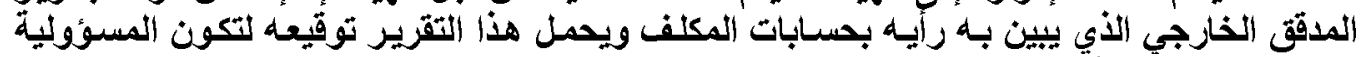

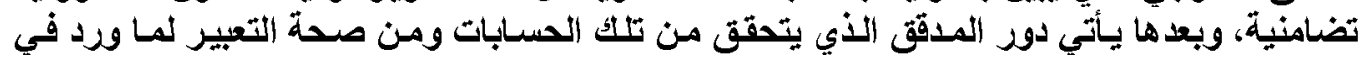

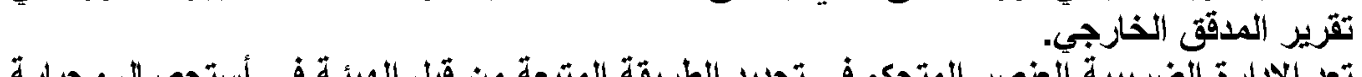

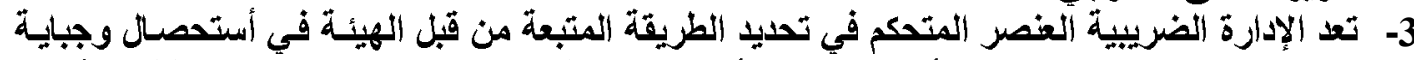

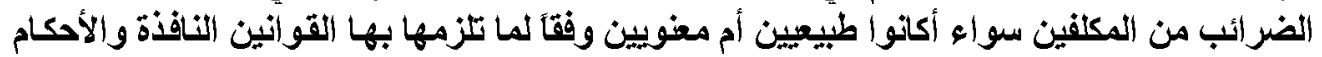

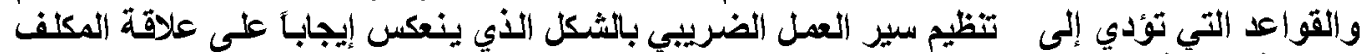
بالسلطة المالية.

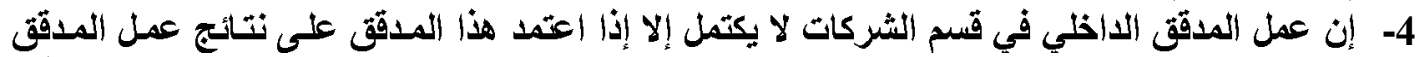

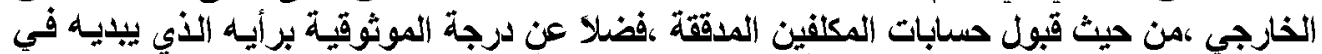

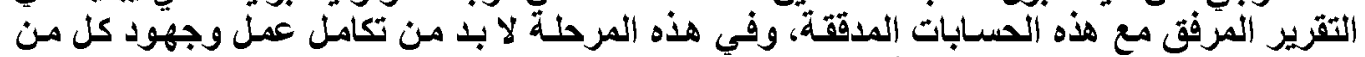

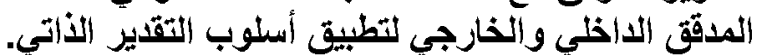

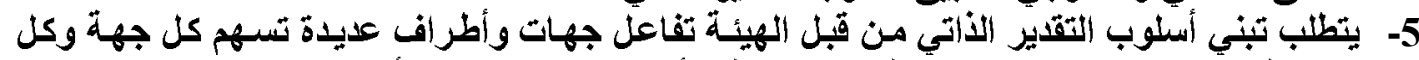

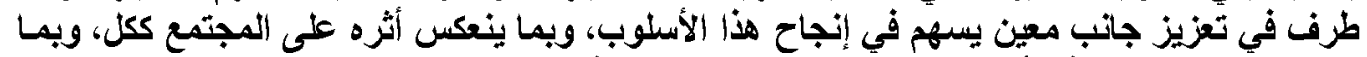

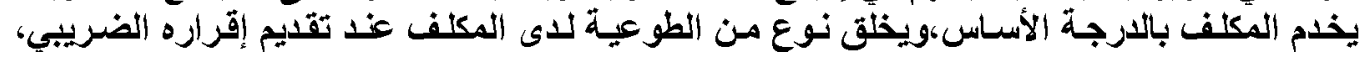

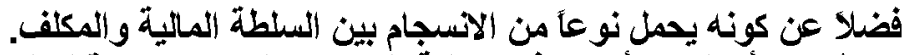

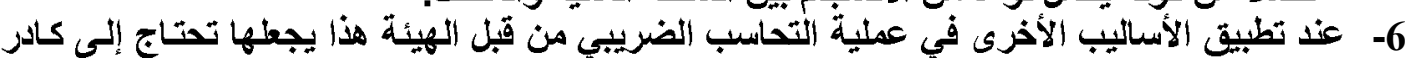

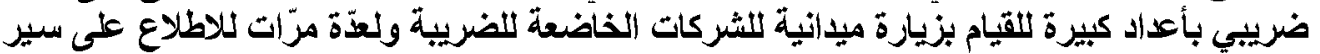

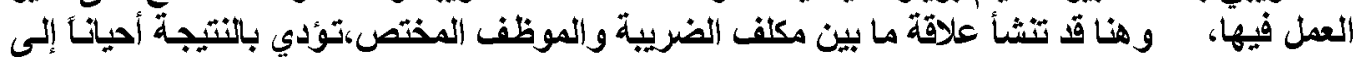

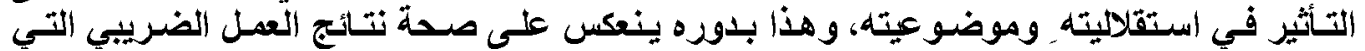

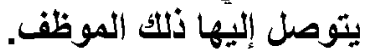

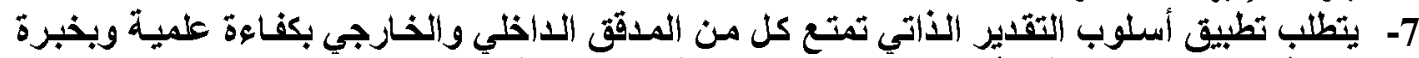

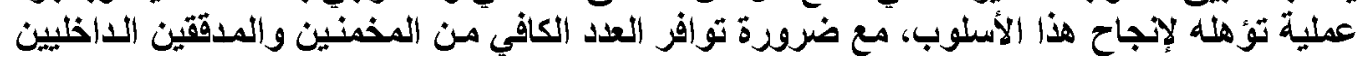

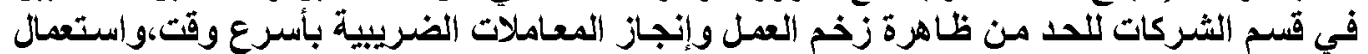

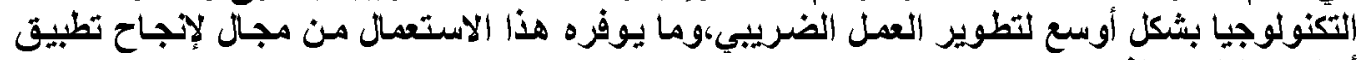
أسلوب التقدير الأتياتي. 


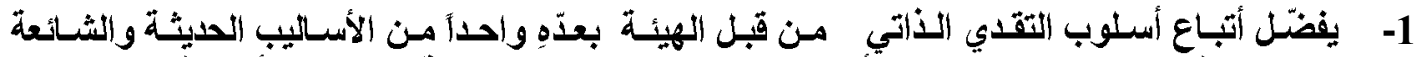

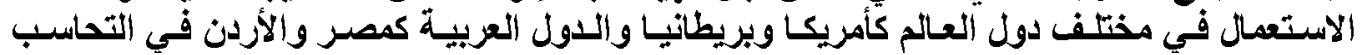

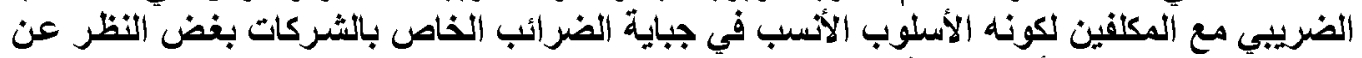

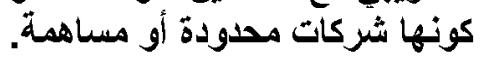

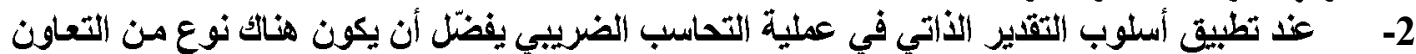

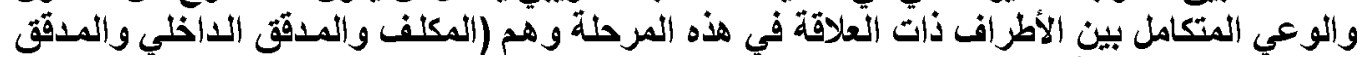

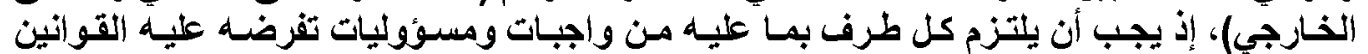

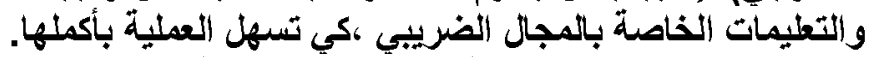

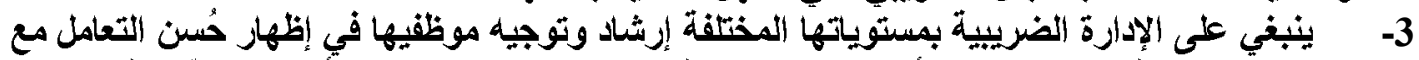

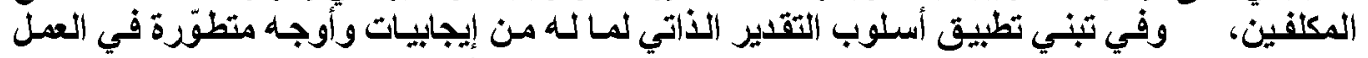

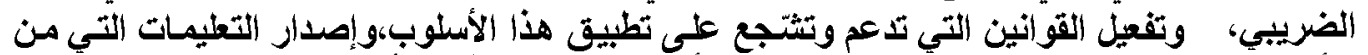

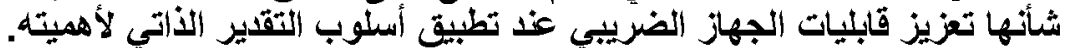

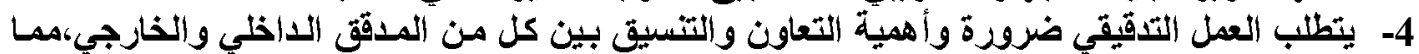

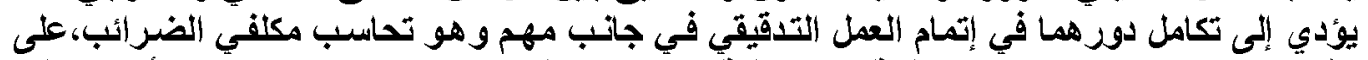

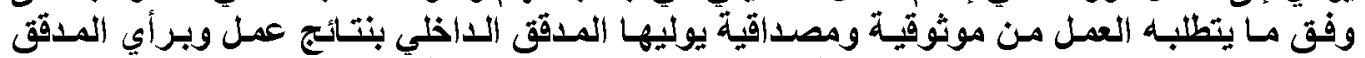

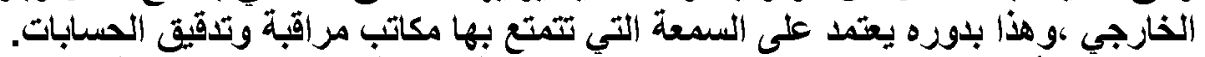

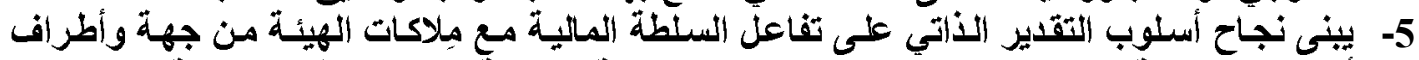

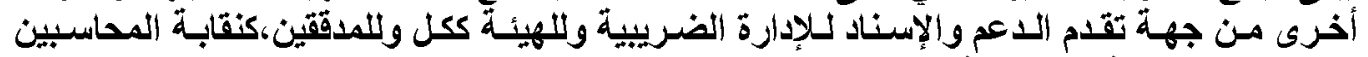

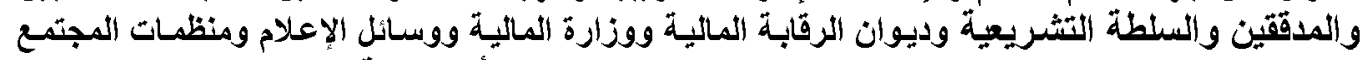

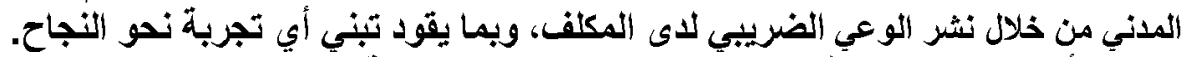

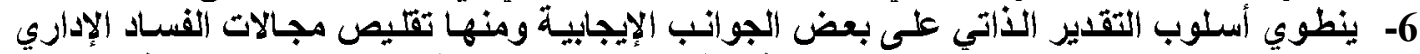

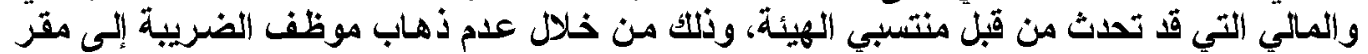

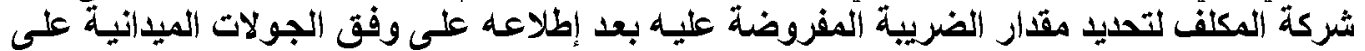
الثركات الخاضعة للضريبة. 7 - ينبخي تفعيل دور شعبة التدقيق الداخلي عند تطبيق أسلوب التقدير الذاتي من خلال إمداد هم بالعدد

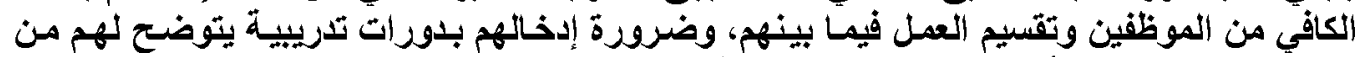

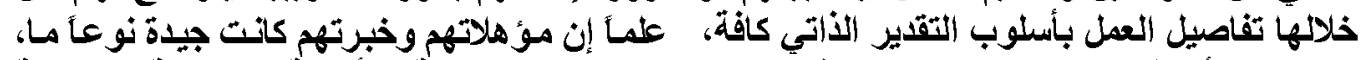

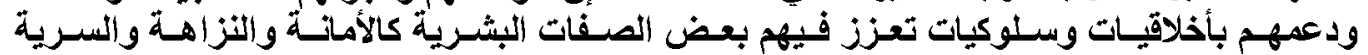

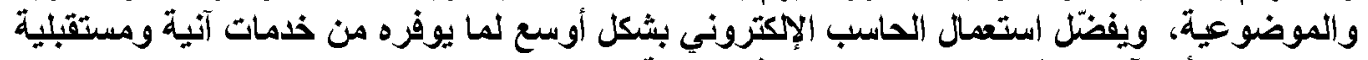
تسهح بشكل أو بآخر بتطوير العمل الضرئي في الهينية. 


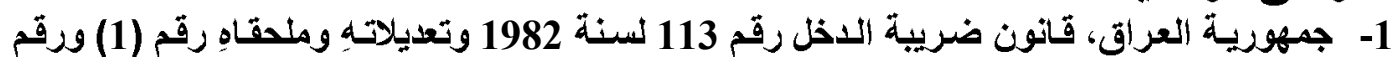

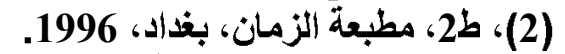

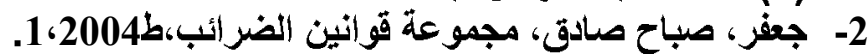

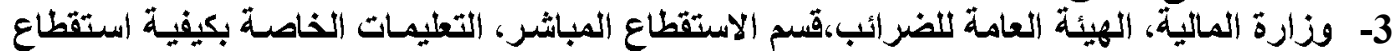

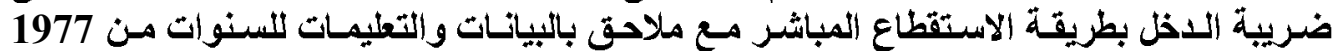

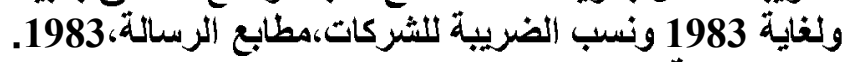

$$
\text { ثانياً الكتب العزبية }
$$

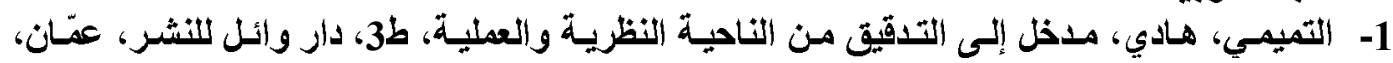
.2006

2- عبد الله، خالد أمين، التدقيق والرقابة في البنوك، طاك، معه الدراسات المصرفية، عثّان، 1998.

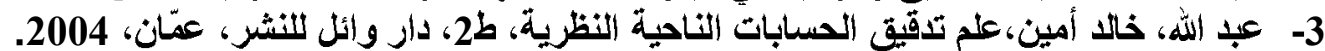

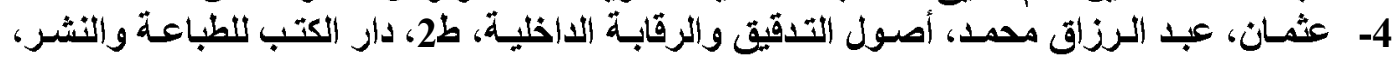
العراق، 1999.

5- عفانة، عدي والثطاونـة، عادل والجدع، أحمد، المحاسبة الضريبية، ط1، دار وائل للنشر، عتّان، 2004

6- المطارنـة، غســان فـلاح، تــقيق الحسـابات المعاصـر الناحيـة النظريـة، ط1، دار المسيرة للنشـر

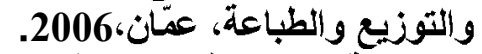

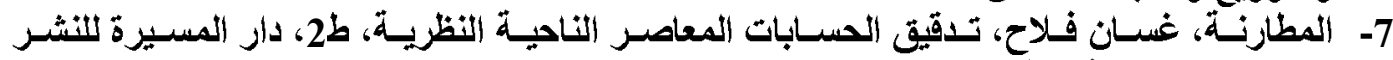

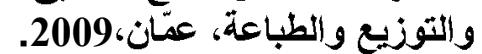

8- نوز، عبد الناصر وعدس، نائل حسن واعن والثريف، عليان، الضرائب ومحاسبتها، ط2، دار المسيرة للنشر والتوزيع والطباعة، عثّان،

9- عطا، محمد حامد، الفحص الضبرعة عمئن، علمأ وعملا- الموسوعة الضريبية، الإسكندرية، 2002.

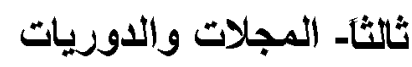

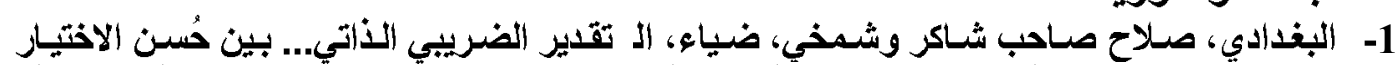

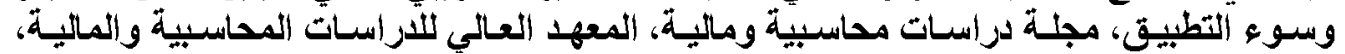

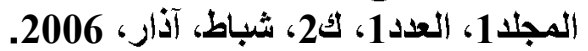

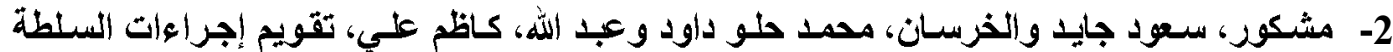

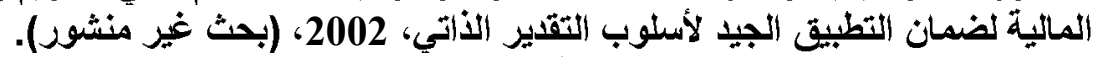

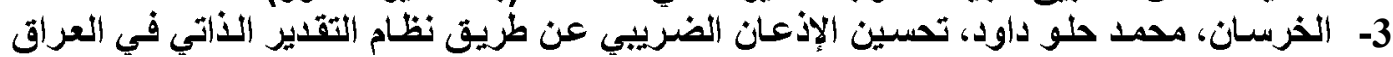

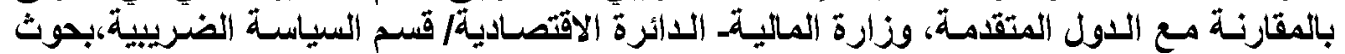

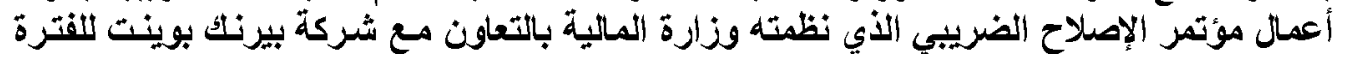


رابعا- الرسائل الأطاريح والبحوث الجامعية

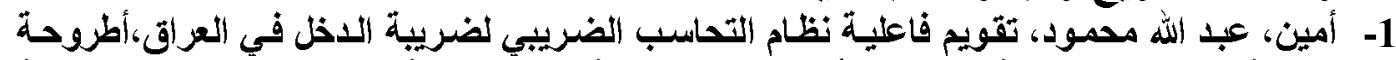

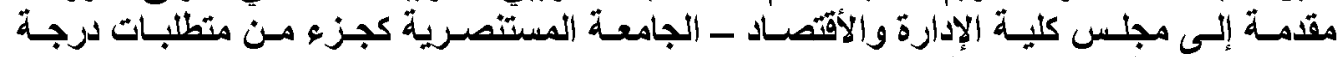

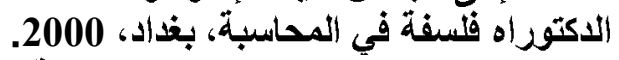

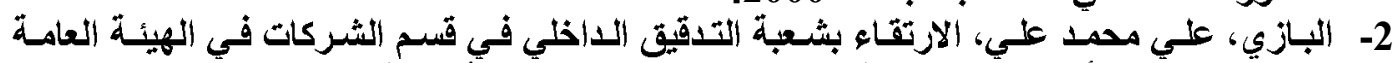

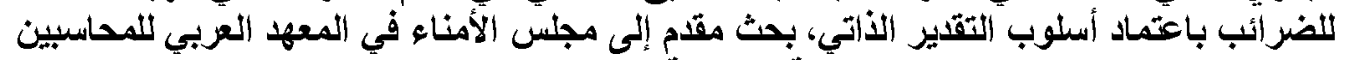

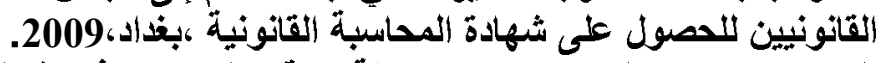

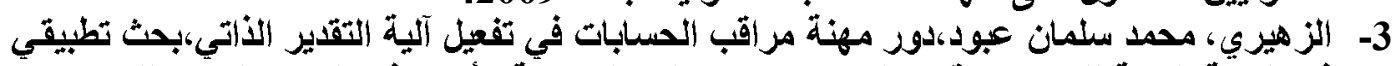

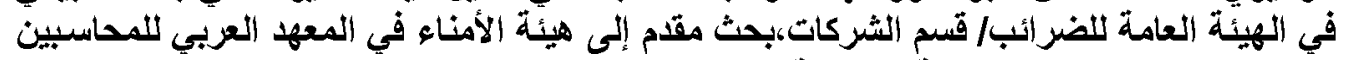

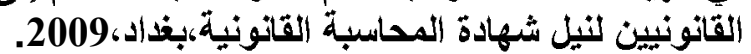

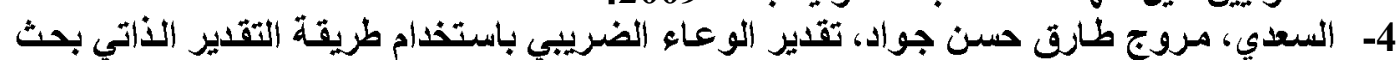

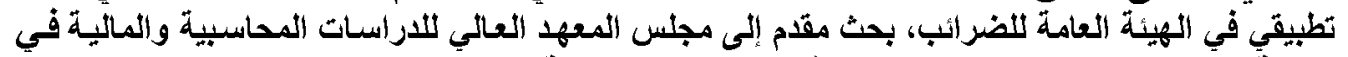

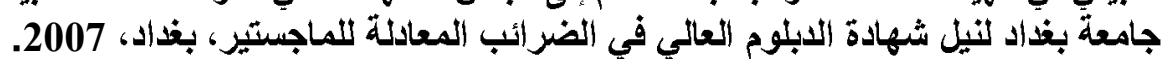

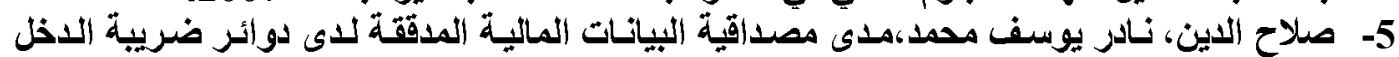

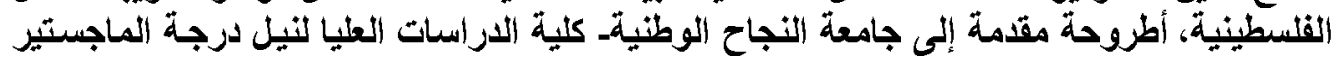

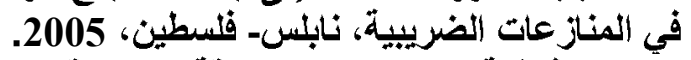

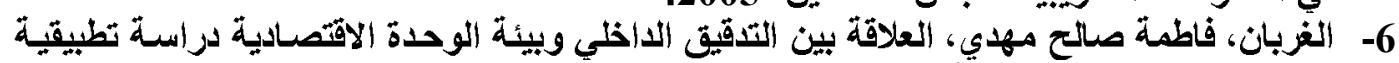

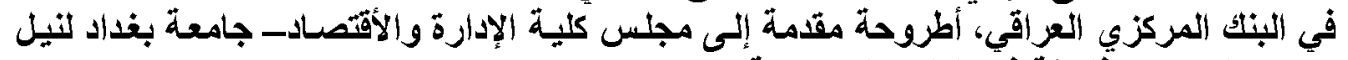

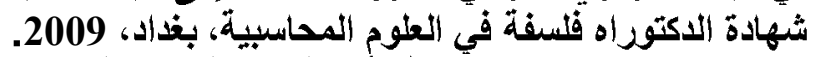

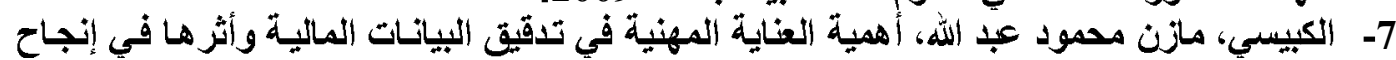

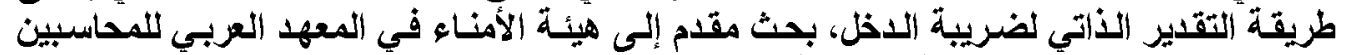

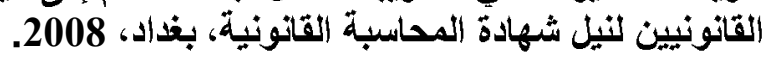

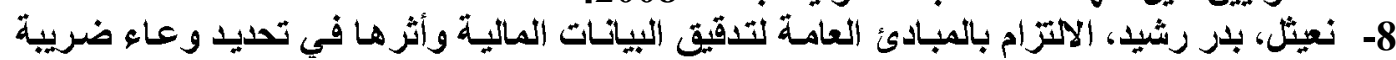

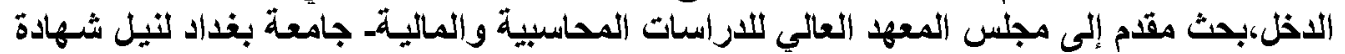

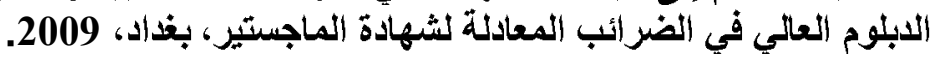

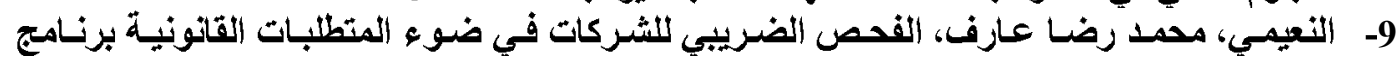

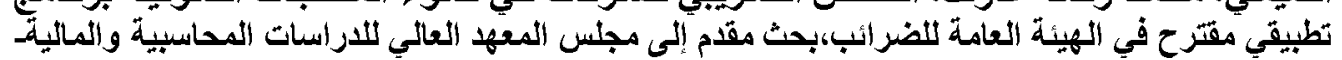

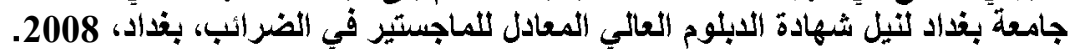

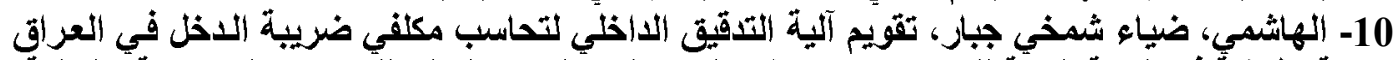

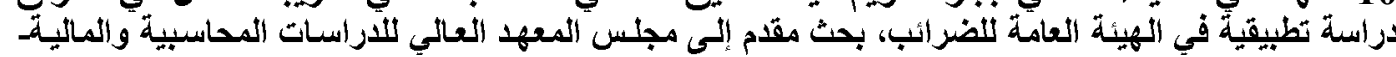

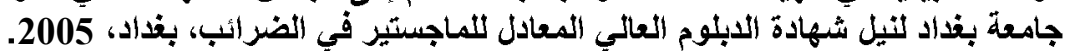


http://www.acc4arab.com/acc

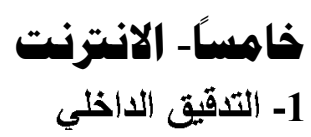

2- الإطلار المهني لممارسـة أعمـال التدقيق الإخلي/تعديلات على الإطلار المهني لممارسـة أعمال التدقيق

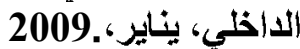

www.ktaby.com.2007

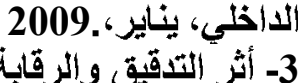

$$
\begin{aligned}
& \text { 3- أثر التقبيق والرقابة على العمل الضريبي }
\end{aligned}
$$

4- سفيان،أسلوب التقيز الذاتي أحد منطبات الإصلاح الضريبي،2570-29-3010. http://www.almadapaper.net/news.php?action=view\&id=14572

ب- المصادر الأجنبية

\section{A- BOOKS}

1- Arens,Alvin A.\&Lobbecke,James K.,"Auditing:An Integrated Approach" ${ }^{\text {th }}$ ed.,NewJersey,Prentice-Hill,Inc.,2000.

2- Arens,Alvin A \&Elder,Randal J.\& Beaslay, Marks.,"Auditing and Assurance Services"10 ${ }^{\text {th }}$ ed.,New Jersey,Pearson Prentice Hall,2005.

\section{B-ENTERNET}

1- IIA,International Standards for the Professional Practice Internal Auditing,2002.

2- Auditing Practices Board(APB),"what is Auditing",London,1996.

3- IFAC," International Standards on Auditing,2003.

http//www. ifac.org / ifac . 